WSRC-TR-98-00045

Publication Date: September, 1998

\title{
The Regional Water Table of the Savannah River Site and Related Coverages
}

R. A. Hiergesell

Savannah River Technology Center

Environmental Sciences and Technology Department

Environmental Restoration Technologies Section

Prepared by:

Westinghouse Savannah River Company

Savannah River Site

Aiken, SC 29808

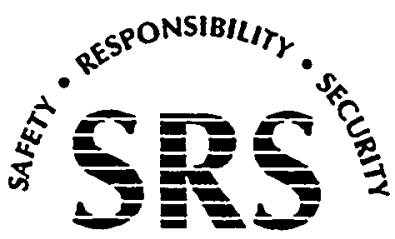

SAVANNAH RIVER SITE

Prepared for the U.S. Department of Energy Under

Contract Number DE-AC09-96SR18500 


\section{DISCLAIMER}

This report was prepared as an account of work sponsored by an agency of the United States Government. Neither the United States Government nor any agency thereof, nor any of their employees, make any warranty, express or implied, or assumes any legal liability or responsibility for the accuracy, completeness, or usefulness of any information, apparatus, product, or process disciosed, or represents that its use would not infringe privately owned rights. Reference herein to any specific commercial product, process, or service by trade name, trademark, manufacturer, or otherwise does not necessarily constitute or imply its endorsement, recommendation, or favoring by the United States Government or any agency thereof. The views and opinions of authors expressed herein do not necessarily state or reflect those of the United States Government or any agency thereof. 


\section{DISCLAIMER}

Portions of this document may be illegible in electronic image products. Images are produced from the best available original document. 


\section{TABLE OF CONTENTS}

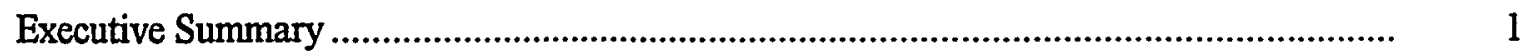

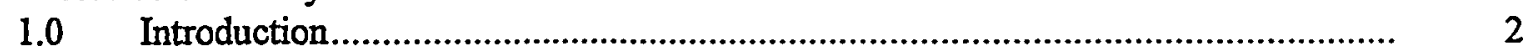

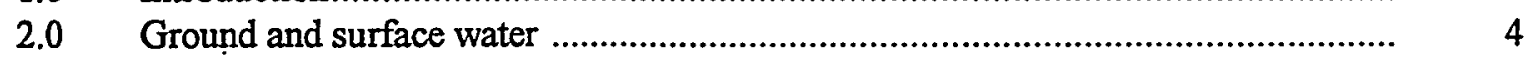

2.1 Hydrogeology ............................................................................... 4

2.2 Groundwater - surface water relationships ......................................... 5

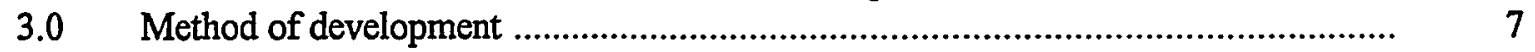

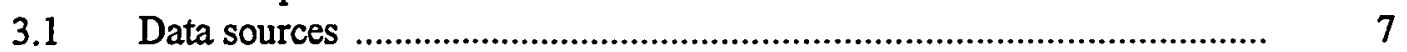

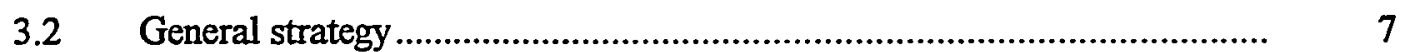

3.3 Field measurements and observations ................................................ 9

3.4 Databases and data processing ........................................................ 10

3.5 Data integration and use of GIS........................................................ 10

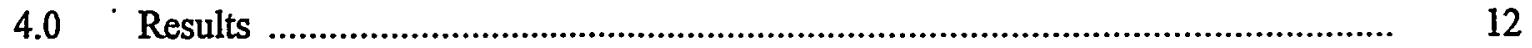

4.1 SRS region ............................................................................... 12

4.2 General Separations Areas .............................................................. 14

$4.3 \quad$ A/M-Area ............................................................................. 14

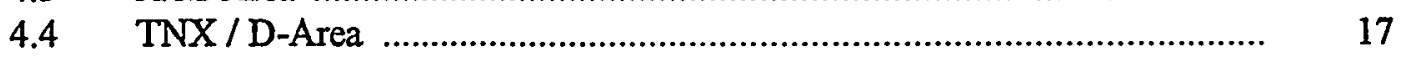

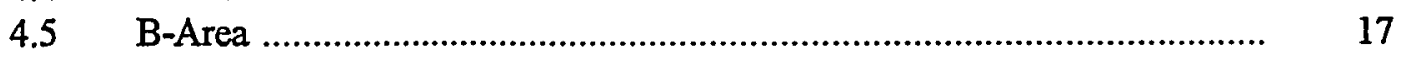

4.6 C-Area / Central Shops .............................................................. 17

4.7 R-Area ................................................................................ 21

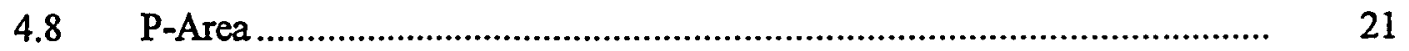

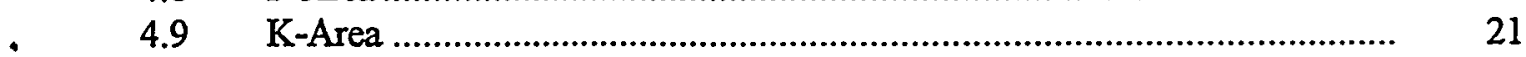

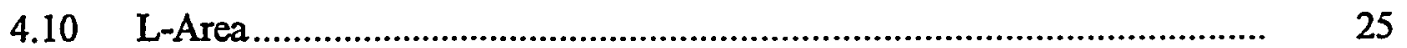

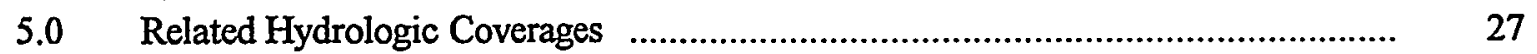

5.1 Perennial stream reaches .................................................................... 27

5.2 Groundwater basins ...................................................................... 27

6.0 Availability of coverages and future refinements ..........................................

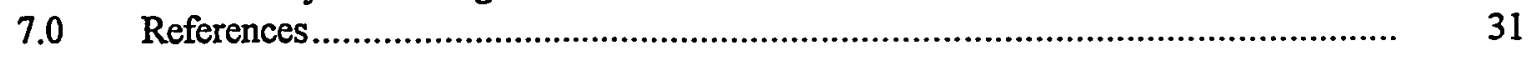

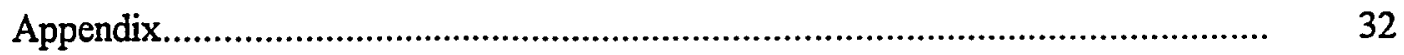

\section{LIST OF FIGURES}

Figure 1 Groundwater flow net for a two-dimensional vertical cross-section through an isotropic, homogenous system bounded on the bottom by an impermeable boundary ........................................................................................ 4

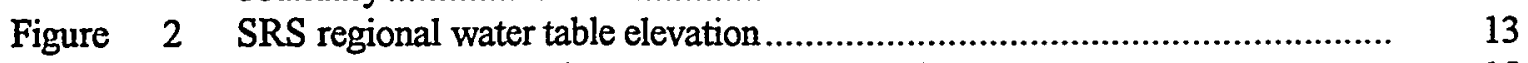

Figure 3 General Separations Areas water table elevation ................................ 15

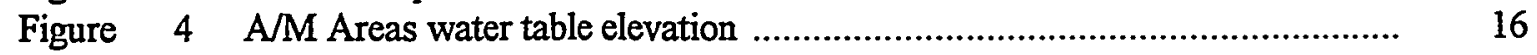

Figure 5 TNX / D-Area water table elevation ..................................................... 18

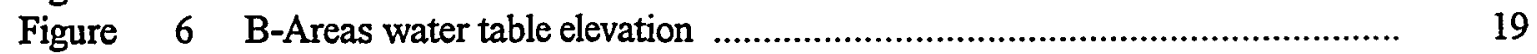

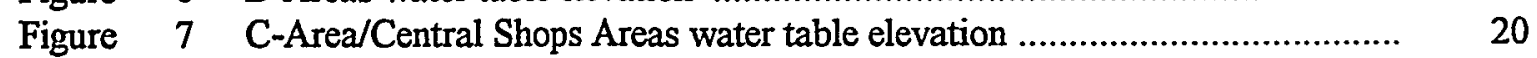

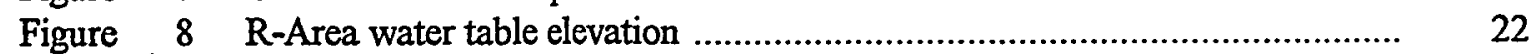

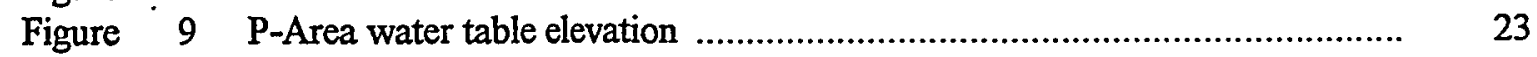

Figure $\quad 10 \quad$ K-Area water table elevation ........................................................... 24

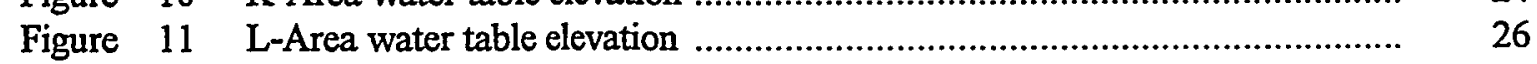

Figure 12 Perennial stream reaches ............................................................. 28

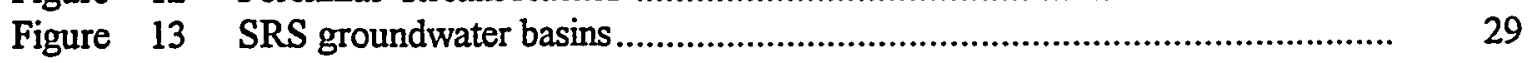




\section{EXECUTIVE SUMMARY}

A new regional-scale map of the water table configuration beneath the Savannah River Site and its surrounding area has been developed. This map is regarded as an update to the regional water table map presented in Hiergesell (1995), and a more accurate representation of this surface than all previous maps. The new coverage can be used: (1) to provide a frame of reference for development of local-scale water table maps, (2) for scoping analyses of contaminant migration, (3) for waste site characterization, and (4) for input to groundwater flow and transport models.

Increased accuracy was achieved by several ways, primarily, by a more thorough processing of water level measurements contained in the SRS database. This processing involved the calculation of simple statistical quantities for each well, including the number of measurements in the period of record, mean elevation, minimum and maximum elevations, and standard deviation. Well information from the SRS database was supplemented by obtaining measurements from a number of water table wells that are not part of the groundwater monitoring program and therefore do not have measurements recorded in any SRS database. This approach resulted in the availability of 946 wells to guide contour development compared to 617 that were utilized to produce the map that appears in Hiergesell (1995). Also, a much more extensive field survey to determine the perennial reaches of surface water drainage ways was conducted. The use of these methods allowed the water table to be contoured with a 10-foot contour interval, compared to the 20-foot contour interval of all previous efforts.

Several other new hydrologic coverages are also presented in this report, including: (1) the extent of continuously flowing natural stream reaches at SRS, (2) the extent of stream reaches that flow artificially, due to SRS operations, and (3) the configuration of groundwater basins associated with each of the major streams at the SRS. 


\subsection{INTRODUCTION}

Efforts to characterize and monitor groundwater contamination sites at SRS was initiated in the early 1960's and has grown tremendously in the intervening years. As part of the characterization process for individual waste sites, knowledge of groundwater flow directions is needed to determine the direction that plumes of dissolved contaminants are moving. Horizontal groundwater flow directions are determined by the water table configuration near these facilities.

Early efforts to characterize sites involved installation of wells relatively close to individual waste disposal sites. As a result, early water table maps tended to focus locally on one or two waste sites. Later, water table maps were extended outward to include entire plumes or entire operations areas. Some of these maps suffered from inaccuracies that arose from a failure to recognize the relationship between the water table and the land surface, particularly in the vicinity of perennial streams. The need for a more regional water table map to serve as a guide for local-scale map development and to minimize map construction errors became apparent.

Other needs also encouraged the development of accurate regional-scale water table maps. These included: (1) scoping needs for subsurface contaminant migration, (2) waste site characterizations, and (3) the development of groundwater flow and transport models that require accurate water table data for boundary condition specification and calibration.

In the past 5 years there have been several efforts to develop regional water table maps for the SRS. The first such map developed is described in Nichols and Haselow (1993). Methodology for development of this map utilized an automatic contouring algorithm to contour well data from 1Q91 and employed some knowledge of land surface elevations near perennial streams. Development of the next available regional water table map is documented in Hiergesell (1995). In this investigation 617 water level measurements obtained from wells during 1Q95 were utilized to construct water table contours. These contours were "hand drawn" and were forced to conform to land surface elevations in the vicinity of flowing streams. The most recent effort to depict the regional water table surface was presented in Brewer (1998). The approach of this effort was to calculate a regional water table surface based upon an empirical relationship between the land surface elevation and the long-term mean water levels in wells for areas lacking well data. Using this relationship a grid was constructed for SRS and a water table elevation assigned to each grid point. The resulting set of values were then kriged and contoured.

All three regional water table maps have a common limitation in that they were developed using only a 20-foot contour interval. Both the Nichols and Haselow (1993) map, and the Brewer (1998) map are also limited in that they were developed using an auto-contouring approach, were not validated with field observations of stream reach points of effluence, and did not extend the coverage beyond the SRS site boundary. The Hiergesell (1995) map was developed utilizing field verification of the point of effluence for many stream reaches within or surrounding SRS, but not all.

Nichols and Haselow (1993) and Hiergesell (1995) maps are limited in the fact that well data utilized to develop the water table were obtained in a single quarter, thus constraining the total number of measurements points available for contouring. The Brewer (1998) map was not constrained by this since mean water levels were used. No indication is given as to how many wells were available for use but, presumably, more wells were available than the number measured in any given quarter. This map is constrained, however, by the use of an empirical 
relationship to establish the water level elevation at points between wells.

In this investigation an updated regional-scale map of the water table configuration beneath the Savannah River Site and its surrounding area has been developed. This map revises the previous regional water table maps that was presented in Hiergesell, 1995

A more thorough processing of water level measurements contained in the SRS database has produced a more accurate and realistic map of the water table. Processing involved the calculation of simple statistical quantities for each well, including the number of measurements in the period of record, mean elevation, minimum and maximum elevations, standard deviation and the standard error of the mean. Following this, a determination was made as to which wells were water table wells, based upon the position of the water level in the well and the screen elevations. One significant advantage of using the historic records to calculate mean water levels for use in development of the regional water table is the fact that additional information, previously obtained from wells that have now been abandoned, became available for use.

Well information from the SRS database was supplemented by obtaining measurements from a number of additional water table wells that are not part of the routine monitoring program. These measurements have not previously been included in SRS databases. The combination of data resulted in the availability of 946 measured control points to guide contour development compared to 617 that were utilized in Hiergesell (1995).

Field surveys were conducted to verify the extent of perennial stream reaches. This effort was a continuation of the field surveys that were begun as a part of the approach in Hiergesell (1995). Knowledge of this is needed because where streams have continuous natural flow, the water table elevation is coincident with the elevation of the stream (or the land surface very close to the stream).

Utilizing all of the above data, contours were developed at the 10-foot interval compared to the 20 -foot interval presented in the three previous investigations. In order to achieve the finer resolution contour interval, more extensive hydrologic interpretations were occasionally required at some locations.

Several other hydrologic coverages, related to the regional water table configuration, are also presented in this report. These include a coverage delineating continuously flowing stream reaches, a delineation of surface drainage ways that have been made to flow continuously through site operations, and a coverage delineating the groundwater basins associated with each of the major streams at the SRS. These basins represent the extent of the area from which groundwater in the water table aquifer moves laterally toward the streams. 


\subsection{GROUND AND SURFACE WATER}

\subsection{Hydrogeology}

Shallow groundwater flow patterns beneath SRS are primarily the result of the incision of the land surface by the network of streams that traverse SRS. Streams occur in drainage ways that serve to divert surface water runoff during times of precipitation events. The process of incision has been ongoing in recent geologic time periods and continues at the present time. Due to the erosive force of flowing water, these drainage ways have progressively cut deeper and deeper into the shallow sedimentary layers through time. The degree of incision is not uniform along a drainage way but has occurred to a progressively greater degree as one proceeds from headwater of each stream to its mouth. This incision and the development of surface topography exerts a primary control on local and regional groundwater flow patterns and the configuration of the water table. The process has been accelerated in surface drainageways that receive a significant amount of process water discharge at SRS. This topic has been extensively investigated and more detailed discussions of the effect of topography on regional groundwater flow systems can be found is various texts, including Freeze and Witherspoon (1967), Freeze and Cherry (1979) and Fetter (1988).

With the use of a groundwater flow net it is possible to depict the steady-state flow patterns within near surface aquifers and the position of recharge and discharge areas of these aquifers. Such a flow net was developed in Hubbert (1940) for a two-dimensional vertical cross section through an isotropic, homogenous system bounded on the bottom by an impermeable boundary. A similar flow net (de Marsily, 1986) is illustrated below in Figure 1 and is useful in illustrating the general flow patterns that develop in a regional groundwater flow system.

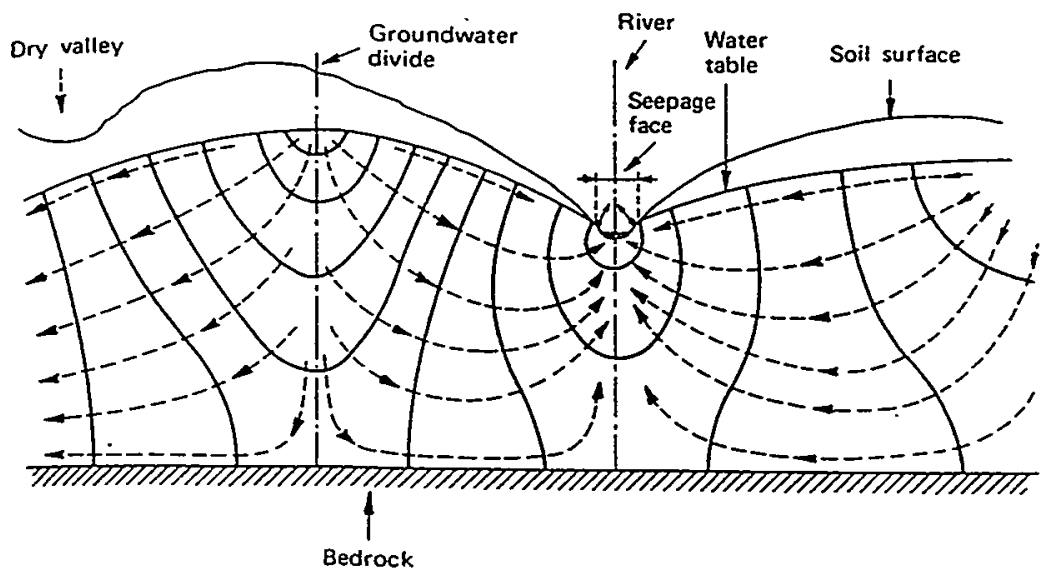

Figure 1. Groundwater flow net for a two-dimensional vertical cross-section through an isotropic, homogenous system bounded on the bottom by an impermeable boundary (from de Marsily, 1986).

In this figure the value of hydraulic head on any of the solid equipotential lines is equal to the elevation of the water table at it's point of intersection with the equipotential line. The direction of groundwater movement, illustrated with dashed lines and arrows, is clearly from areas of land surface highlands toward the valleys. Beneath divide areas groundwater moves vertically downward, then laterally toward the valleys and finally vertically upward beneath the 
streams. Water table elevations in the upland areas are maintained by recharge while groundwater discharge occurs in the vicinity of flowing streams. Recharge and discharge areas are those areas of the drainage basins where the net movement of groundwater is either away from the water table or toward it. (Freeze and Cherry, 1979). In a three-dimensional sense the water table is a subdued expression of the land surface topography. The higher elevations of the water table are located between perennial streams while the lowest areas are located along the streams themselves. Water table divides are roughly coincident with the surface water divides, although the water table occurs at some depth below the land surface.

In reality, the use of steady-state flow nets is technically valid only for the somewhat unrealistic case where the water table remains in a static position throughout the year. Use of the concept is still useful, however, when water table fluctuation is small relative to the entire thickness of the water table aquifer and if the water table configuration remains highly similar at all times in the fluctuation cycle. The steady-state groundwater condition should be regarded as one of dynamic equilibrium in which the recharge flux delivered to water table is the flux necessary to maintain the water table in its equilibrium position (Freeze and Cherry, 1979).

The water table is the upper surface of the saturated zone. Although the term "Water Table Aquifer" is sometimes used at the SRS, the regional water table is not constrained to occur exclusively in a particular hydrostratigraphic unit but actually occurs in different aquifers depending upon location.

The subsurface groundwater flow patterns can deviate from what is normally expected due to the existence of geologic complexity within the flow field. Variation of geologic depositional environments in both the horizontal and vertical direction often creates a hydraulic conductivity distribution field that varies widely within individual units as well as between units. This geologic complexity occurs not only within the saturated subsurface but also in the overlying unsaturated zone and may lead to complex saturated-unsaturated conditions. (Freeze and Cherry, 1979). When a low-permeability clay layer exists within a highly permeable sand unit the formation of a discontinuous saturated lens having unsaturated conditions above and below can occur. These lenses of saturated material are referred to as "perched" water. Perched lenses can be discontinuous in time as well as space. During periods of high rainfall perched lenses may form, only to dissipate during dryer times. Perching of water is suspected to occur at some parts of SRS but is difficult to verify.

\subsection{Groundwater - surface water relationship}

Groundwater and surface water are related due to the hydraulic connection that exists between the two flow domains. Several significant relationships can be identified that are relevant to this study. One groundwater - surface water relationship of primary importance for development of a water table map is the fact that the water table elevation is coincident with the land surface elevation along the reaches of continuously flowing, or perennial, streams. Where streams are known to be perennial, the water table elevation is known as accurately as the land surface elevation is known in those localities. Land surface elevation is available for the entire SRS by use of the USGS 7.5 minute quadrangle sheets. These sheets provide land surface elevations with a 10-foot contour interval and have an accuracy of $+/-1 / 2$ the contour interval. As a result, the land surface elevation is known to an accuracy $+/-5$ feet along all stream reaches at SRS. Some error due to the digital processing of DEM data may also contribute to elevation uncertainty along streams on scales smaller than the 30-meter distance between data points. Erosion along certain stream reaches has also contributed a significant elevation reduction along some minor tributary streams, especially the outfall streams near some of the operations areas. Information about water table elevation in 
the vicinity of streams is especially important at SRS because these areas are generally devoid of any piezometers or wells.

A second significant groundwater - surface water relationship is that surface streams are discharge zones for shallow aquifers. It can be demonstrated that naturally occurring SRS streams increase in flow rate from their point of effluence to the point where they flow into other, larger, streams and rivers. This relationship is observed even in the driest extreme of SRS climatic conditions, when practically all stream flow can be attributed to discharge from shallow aquifers.

The fact that naturally occurring SRS streams gain flow continuously along their extent from groundwater discharge is significant in that it implies that a fluid potential gradient must exist within the groundwater flow field near streams that drives groundwater toward the streams. In order for groundwater to move horizontally toward the streams, equi-potential lines (water table contour lines) must assume a "V" shape, with the apex pointing in the upstream direction. This configuration is similar to the configuration of land-surface elevation contour lines in the vicinity of incised stream valleys.

Some surface water flow at SRS is the result of continuous discharge of process water at the head of surface drainage ways. Such reaches are referred to in this report as "artificially flowing" stream reaches and represent locations where the groundwater flow system receives recharge from the stream. These reaches have been demonstrated to have flow rates that decrease from the discharge point (typically an NPDES outfall) to a point where groundwater begins to discharge naturally to the stream. The fact that flow decreases along such reaches indicates that surface water is seeping into the streambed and recharges the underlying aquifer. In order for groundwater to move horizontally away from the streams, equi-potential lines (water table contour lines) must assume a "V" shape, with the apex pointing in the downstream direction. Two examples of this condition exist at the A-01 and A-14 outfalls in the A/M Area. The drainage ways below these outfalls both flow continuously from the outfall to the mouth of Tims Branch. One study provides direct evidence that stream flow decreases below the A-14 outfall (WSRCOS-97-00004). Measurements from nearby wells also provide evidence that groundwater is moving horizontally away from these reaches, immediately downstream from the outfalls to a point where Tims Branch begins to gain flow naturally from the shallow aquifers. 


\subsection{METHOD OF DEVELOPMENT}

\subsection{Data sources}

Three basic types of data were used in this investigation to construct the regional water table contours. These included:

- Water level elevations from wells

- Land surface topography

- Continuously flowing stream reaches

One of the principal sources of data for development of the water table configuration is the historic record of water level measurements at SRS maintained by the Environmental Monitoring Section (EMS). Wells that are part of the on-going groundwater monitoring network are visited at least bi-annually to collect groundwater samples. Several parameters are measured in the field each time a well is visited, including the depth to water below the top of the standpipe, if the well has a standpipe, or below the top of casing. Each well is surveyed to provide accurate vertical and horizontal control, hence water level measurements are easily converted to water level elevation by subtracting the depth measurement from the surveyed elevations of the wellhead reference point. Water level information is entered into the GIMS database on a quarterly basis along with the analysis results from the samples. This database is maintained at WSRC by EMS.

Many wells at SRS were not specifically installed to become a part of the groundwater monitoring network, but rather to obtain baseline information on water levels and water chemistry. Data from these wells has not been entered into the site database and is not available by an electronic search of the GIMS database. As a part of this investigation, many of these wells were visited and one-time measurements were obtained to supplement the historical measurements stored in GIMS. The majority of these wells were installed in very remote parts of the SRS and have great value in reducing overall uncertainty in the water table configuration. The strategic location of these wells offsets the fact that "one-time only" measurements are utilized instead of a mean elevation from multiple measurements.

The land surface elevation information was acquired from the U.S.G.S. 7.5 minute quadrangle sheets. The SRS is completely covered by 14 quadrangle sheet, these being:

$\begin{array}{ll}\text { Girard } & \text { New Ellenton } \\ \text { Girard NE } & \text { New Ellenton SE } \\ \text { Girard NW } & \text { New Ellenton SW } \\ \text { Jackson } & \text { Shell Bluff Landing } \\ \text { Long Branch } & \text { Snelling } \\ \text { Martin } & \text { Williston } \\ \text { Millett } & \text { Windsor }\end{array}$

These quadrangle sheets have land surface elevation contours of 10-feet although there are 5-foot contours on some quadrangles in the Savannah River floodplain.

Finally, information on perennial streams is also available on the 7.5 minute quadrangle sheets where such reaches are shown with a solid blue line while intermittently flowing stream reaches are illustrated using a dashed line. However, the point of transition from intermittent reach to continuously flowing reach on these maps is often considerably different than the transition point determined from direct field observation.

\subsection{General strategy}

One of the key strategies in development of the regional water table configuration is the use of the conceptual steady-state model to describe the water table. Water table elevations in wells at SRS are known to vary in response to transient recharge events, however the conditions identified in Section 2.1 for the practical employment of the 
steady-state model are not violated in terms of water table fluctuations. Additionally, it can be demonstrated with the use of quarterly water table maps that the general water table configuration does not change appreciably due to annual fluctuation cycles.

Steady-state water table elevations were estimated by calculating the long-term mean water level elevation for each well. The range of water table elevations during the period of record for each well was also calculated. The mean of the range of fluctuation for all wells having multiple measurements ( 910 wells) was found to be 7.2 feet. Seventy seven percent of the wells had a range of less than 10 feet. This statistic represents the range of water table fluctuation from the driest conditions to the wettest conditions and thus reflects the response to the extreme range of climatic conditions. Some wells will fluctuate more than others based only on their location. Wells situated near groundwater divides tend to have a greater fluctuation ranges than wells located closer to perennial streams.

Since the range of climatic conditions over the period of record is greater over longer periods of time than in any given year, it follows that the range of water level fluctuation is greater over the period of record than in any given year. While the annual fluctuation varies from year to year it is usually less than 4 feet in any year. The magnitude of this range of fluctuation is small compared to the total thickness of the water table aquifer. These comparisons serve to justify the use of mean water levels to characterize the regional water table.

The decision to utilize a steady-state model of the water table has a very practical benefit over the alternative method of utilizing the approximately "time-synchronous" measurements from a single quarter to develop the water table configuration. The benefit is derived from the fact that many more wells are available to calculate a long-term mean elevation than are measured in any specific quarter. Approximately 617 well measurements were previously available in $1 \mathrm{Q} 95$ to support the development of a water table configuration (Hiergesell, 1995) compared to 910 mean water table elevations available for this effort. This difference is primarily due to the fact that well samplers do not visit every well at the SRS in any particular quarter. Another contributing factor is that when there is a historical record of water level measurements from a well that has since been abandoned, the measurements can still be utilized as a control point at the location where the well once existed. One disadvantage of the use of abandoned wells is that the period of record of measurements obtained for some wells does not overlap with the period of record of measurements from newer wells. This is not thought to be significant disadvantage since a mean water level is used to estimate the water level at any well, therefore, the advantage of having many more data points available for contour development outweigh this disadvantage.

Although most monitoring wells at SRS are water table wells, many other wells have their screen zones finished in deeper aquifers and cannot be used to describe the water table. A water table well, by strict definition, must have the water level occur within the screen zone. According to SRS protocol, a well intended to monitor the water table is constructed with a 20$\mathrm{ft}$ screen and is installed such that the 5-feet of the screen are above the water table and 15-feet below the water table at the time of installation. In order to increase the number of wells that could be used to construct the water table elevation contours an evaluation was conducted to determine if certain wells could also be utilized if their mean water level occurred slightly above the top of the screen zone. In the situation where the water level elevation in a well is positioned slightly above the screen zone, the measured water level will be slightly lower than the true water table. This is because of a slight head loss that occurs as water migrates vertically downward in the aquifer (i.e. from the water table to the top of the screen zone). A vertical distance of 5-feet above the screen was selected to evaluate the deviation from the true water table that could occur over this distance. 
Assuming a relatively high vertical gradient $(\Delta \mathrm{h} / \Delta \mathrm{l})$ of 0.2 and the distance of 5 feet over which a drop in hydraulic head could occur, the following calculation was made:

$$
\begin{aligned}
\text { Decline } & =(\Delta \mathrm{h} / \Delta \mathrm{l}) *(\Delta \mathrm{l}) \\
& =(0.2) *(5)=1.0 \mathrm{ft} .
\end{aligned}
$$

where:

$\Delta \mathrm{h}=$ head difference

$\Delta \mathrm{l}=$ the vertical distance over which head

difference occurs.

$\Delta \mathrm{h} / \Delta \mathrm{l}=$ vertical gradient

Estimates of vertical gradient can be obtained directly from well clusters at SRS. Data obtained from the MSB- 47 cluster indicate the maximum vertical gradient is less than 0.2 , although the vertical gradient in the vicinity of the water table is much less than 0.2. (Hiergesell, 1994). Thus, for wells in which the water level is less than five feet above top of the screen, the well level is less than $1.0 \mathrm{ft}$. below the true water table outside the well. This tolerance is regarded as acceptable for construction of a regional water table map, especially when considering the large number of wells that would otherwise be excluded from use.

\subsection{Field measurements and observations}

To supplement the topographic and perennial stream reach delineation of the 7.5 minute quadrangle sheets, a field survey was conducted to verify the map information. This survey was conducted by driving to every location where a road or trail crossed the headwaters of a minor stream and making a visual check. The survey was conducted both on the SRS and also in the area immediately surrounding SRS, although no survey was conducted on the Georgia side of the Savannah River. The map information on that side of the river was assumed to be accurate in regard to.flowing stream reaches, but as a result water table contours were not reduced from 20 feet to 10 feet on the Georgia side of the river. Along a few headwater reaches access could only be obtained on foot. Visual examinations at each observation point were for the existence of flowing water, channel development, extent of wet soils and vegetation types associated with continuously wet soils. Field surveys were timed to coincide with times thought to reflect baseflow conditions of site streams. Using this constraint, any observed flowing reach with channel development could reasonably be assumed to be a perennial reach.

A field survey was conducted to obtain water level measurements from wells that are not part of the groundwater monitoring program at SRS and which have no water level measurements in the GIMS database. Such wells were identified by comparing files listing wells for which there are water level measurements with files containing surveyed well information. These wells were installed primarily to provide background information on water levels and groundwater chemistry at locations that were under consideration for siting of new facilities at the SRS. Because these wells are located in areas where no disposal of contaminants has occurred there has never been a need to include them in the groundwater monitoring program. Generally, the locations of these wells are highly desirable for the purpose of constructing regional water table elevation contours due to their being in remote parts of the site near groundwater divide areas. No other information on water table elevation is available in these areas. The uncertainty reduction in the water table elevation that is gained by the use of these wells is considered to be much greater than the uncertainty that is added by the use of a well with a single measurement. These wells have been added to a monitoring program and multiple measurements will be available at a later date to equate these measurements with mean water levels obtained from other water table wells.

A listing the 20 wells for which a single water level measurement was utilized is presented at the end of the table of wells in the Appendix. No statistical quantities are presented for any of these wells. 


\subsection{Databases and processing}

Database operations were performed using the Heuristic Optimized Processing System (HOPS) data engine. The HOPS database has been populated with files containing a wide variety of environmental data from SRS. Files containing all of the groundwater data for SRS are periodically downloaded from the GIMS database where they are officially stored. Once data is entered into the HOPS data engine, the HOPS seed tool can be utilized to extract and process data of interest. The seed tool is easy to use and contains a Statistical Toolbox and Graphical Package and is capable of performing complicated queries extremely rapidly (Bowers, et. al. 1995).

Initial work was conducted to standardize common fields in different files such that database queries could be conducted using the common field to relate the data. In this case the well construction file had to have a common field with the file containing the historical water level measurements.

After this, simple statistical summaries of water level elevations were then calculated for each well having recorded water levels in the GIMS database. The statistical quantities calculated with HOPS included the number of measurements in the period of record, the mean, maximum, minimum, and standard deviation, and the standard error of the mean.

Analysis of the statistical quantities revealed that a number of wells had relatively high standard deviations, greater than 8 feet. Further investigation revealed a large difference between maximum and minimum water level elevations for these same wells. The most frequent problem contributing to this situation was found to be the existence of a single measurement from such wells that was much different from all other measurements obtained from the same well. Occasionally, there was more than one anomalous measurement. These measurements were frequently offset 100 feet from an elevation that fell within the range of the remaining measurements. The anomalous values were eliminated from the well files created with HOPS and the summary statistics then re-calculated. Readings were regarded to be anomalous if they differed from the remaining measurements by 30 feet or more and there were not more than two such measurements associated with any well. The total number of anomalous, and probably erroneous, measurements is a very small percentage of all water level measurements that are stored in GIMS. A list of the anomalous values was provided to EMS so they could make a determination if individual measurements stored in the GIMS database should be eliminated.

Another statistical quantity, the standard error of the mean, $\sigma_{m}$, was calculated and provides a measure of the accuracy of the sample mean as an estimator of the population mean. This statistic ranged from 0.01 to 2.88 feet.

Next, an evaluation was conducted to determine which wells were "water table" wells. This was accomplished by determining the position of the mean water level from each well relative to its well screen. The criterion used to determine which wells are water table wells was whether the mean water level occurs between bottom of the screen zone and a position 5-feet above the top of the screen. The justification of this criterion was previously discussed in Section 3.2, General Strategy, and a listing of all wells which meet this criterion are presented in the Appendix.

\subsection{Data integration and use of Geographic Information System (GIS)}

Management of hydrogeologic coverages was conducted using a Geographic Information System (GIS). The particular GIS used was ArcView, a product of ESRI, Inc. This program was used to superimpose related coverages so that water table contours could be configured to honor all relevant data. Coverages regarded as relevant to construction of accurate water tables include several exisiting coverages as well as new 
data collected specifically to improve the water table contours.

New data resulted from the previously described data base work to calculate mean water levels and from field surveys to observe continuously flowing stream reaches. The water levels obtained from one-time field measurements are also considered to be new data. Tables were created containing the pertinent information for each well, including: well name, well coordinates, mean water level, maximum and minimum water level, standard deviation of water levels, and the number of measurements in the period of record for each well. The tables were then loaded into ArcView so that well locations and water levels could be posted. Other previously existing GIS overages needed to configure the 10-foot water table contours included: Land surface elevations (images of USGS quadrangle sheets); NPDES outfall stations; and the 1Q95 Water table contour (20-ft).

The initial step involved the development of a new coverage depicting perennial stream reaches. Streams were assumed to follow the stream channel path illustrated on the USGS 7.5 minute quadrangle sheets. The point of effluence was determined for each surface drainage way based primarily on field observation of it's continuously flowing reach, but also involved applying a best estimate for headwater reaches of some tributaries that could not be field checked. Once the coverage for continuously flowing streams was created, the locations where water table contours are coincident with land surface contours were defined.

Key coverages that provided control for configuring the water table contours were the well locations (with water table elevations), the land surface elevation contours and the flowing stream reach coverage. These coverages (ArcView themes) were all activated within the same ArcView project view. The 20-foot water table contours were then added, as well. Once all the coverages were super-imposed, 10-foot water table contour lines were digitized between the 20- foot water table contour lines. Then all contours were adjusted using the ArcView theme editing function to honor the posted water level values and the land surface elevations in the vicinity of streams. Extensive modification was required to adjust all water table contours to be consistent with all of the control data on the local-scale.

After the all adjustments were completed, another coverage was created to represent the boundaries of groundwater basins associated with each stream drainage way at SRS. Since basin divides represent no-flow groundwater boundaries, their configuration is such that the boundary lines are oriented perpendicular to water table contour lines and parallel to groundwater flow lines. 


\subsection{RESULTS}

The work conducted in this investigation has resulted in a significant increase in the accuracy of the water table map for SRS and the area immediately surrounding its boundary. This is due primarily to the availability of additional control points used to constrain the water table surface, thus allowing the reduction of the contour interval of the regional water table map from 20 -feet to 10 -feet.

The total number of wells was increased from 617 to 946 for this investigation. Although many of the additional 329 wells are in areas where many other wells already existed, a considerable number occur in areas where no other well information existed. This was an important factor in the increase in accuracy. Another factor contributing to the increased accuracy was the effort made to assure that water table contours were coincident with land surface contours along flowing stream reaches. A major effort was made to assure that this stream-aquifer relationship was strictly adhered to at a localscale.

In general, the degree of accuracy of the water table elevation is greatest in those areas where groups of wells exist. The accuracy is slightly less where isolated wells exist and along perennial stream reaches. The least accurate parts of the map are at groundwater divide areas where there are no well measurements. Water table contours in these areas were extrapolated based upon the land surface elevations along perennial stream reaches in adjacent areas, and assuming mounding occurs to a similar degree as in other parts of SRS. There are three main areas at SRS where this situation occurs. These are: the portion of SRS located north of Upper Three Runs Creek and east of Tims Branch, the divide between Upper Three Runs Creek and Tinker Creek, the divide between Tinker Creek and Lower Three Runs Creek and Tinker Creek, and the divide west of Lower Three Runs Creek and east of Steel Creek. Uncertainty in water table elevations at these locations cannot be reduced without the acquisition of additional water table elevation measurements.

\subsection{SRS region}

The configuration of the regional water table beneath the SRS is presented in Figure 2. The most prominent feature of this surface is the high degree to which the water table is controlled by incision of site streams into the shallow sediments. Also prominent is the "V" nature of water table contours, pointing in the upstream direction of the different SRS streams. These, and other features, are explained in Section 2.1 (Hydrogeology) and Section 2.2 (Stream Aquifer Relationships).

The highest elevation of the water table within the SRS boundary is approximately 310 feet above mean sea level, occurring at the peak of the broad mound located near center of SRS. The headwaters of many of the site streams occur on the flanks of this mounded area. Other mound areas occur northeast of the A/M Area, and in the southeastern part of SRS between Lower Three Runs and Meyer Branch. Distinct "ridges" occur along the groundwater divides between surface streams. The lowest water table elevation within the SRS boundary, 70 feet above mean sea level, occurs near the mouth of Lower Three Runs Creek, where it flows into the Savannah River.

Groundwater gradients are greatest along the flanks of the major drainage ways. In particular, steep gradients occur on the south side of Upper Three Runs Creek. The lowest, or flattest, gradients occur near the mounded areas and along groundwater divides.

The water table configuration has been altered somewhat in the vicinity of the surface water impoundments, most notably L-Lake and Par Pond, but also at several of the smaller 


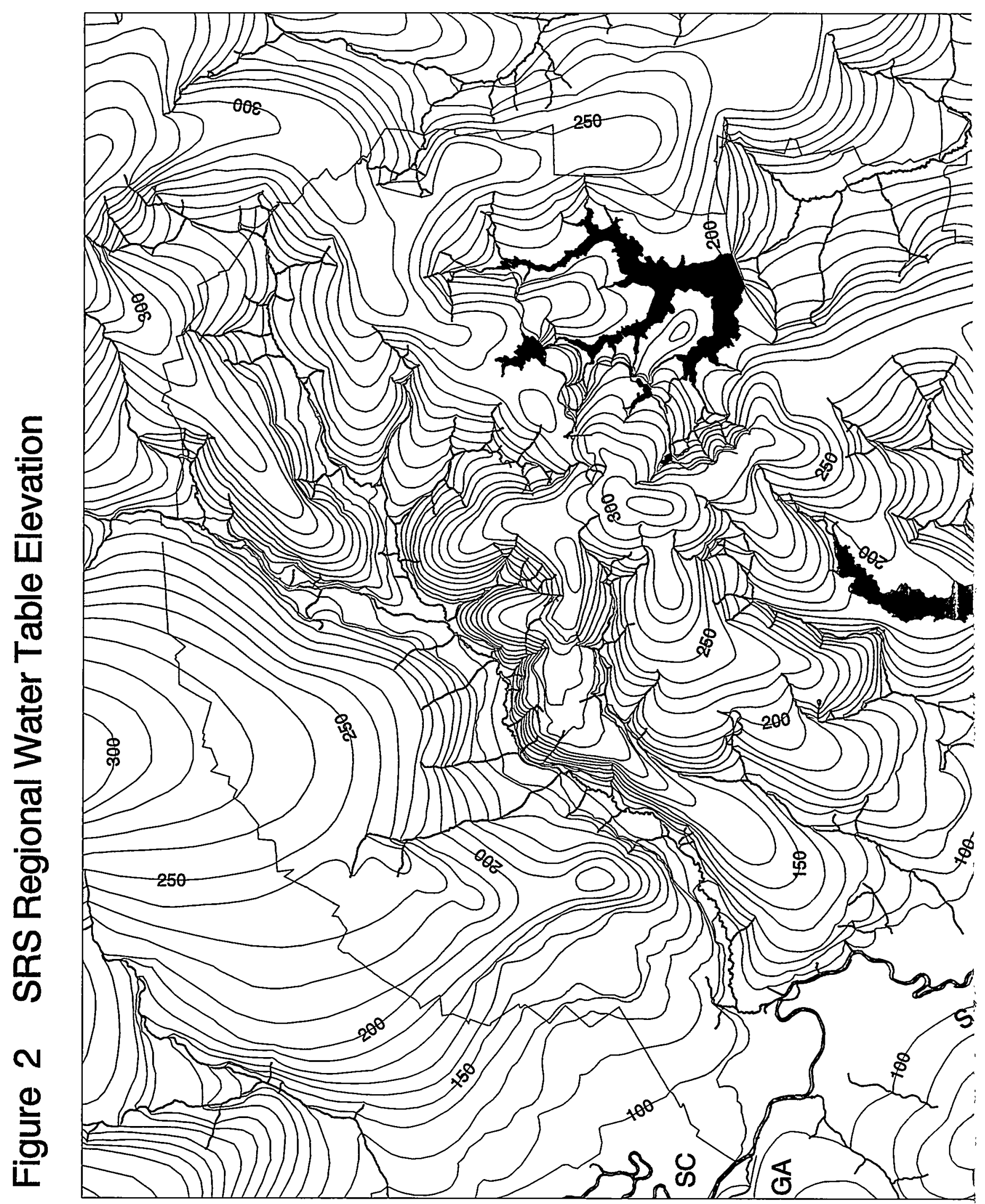




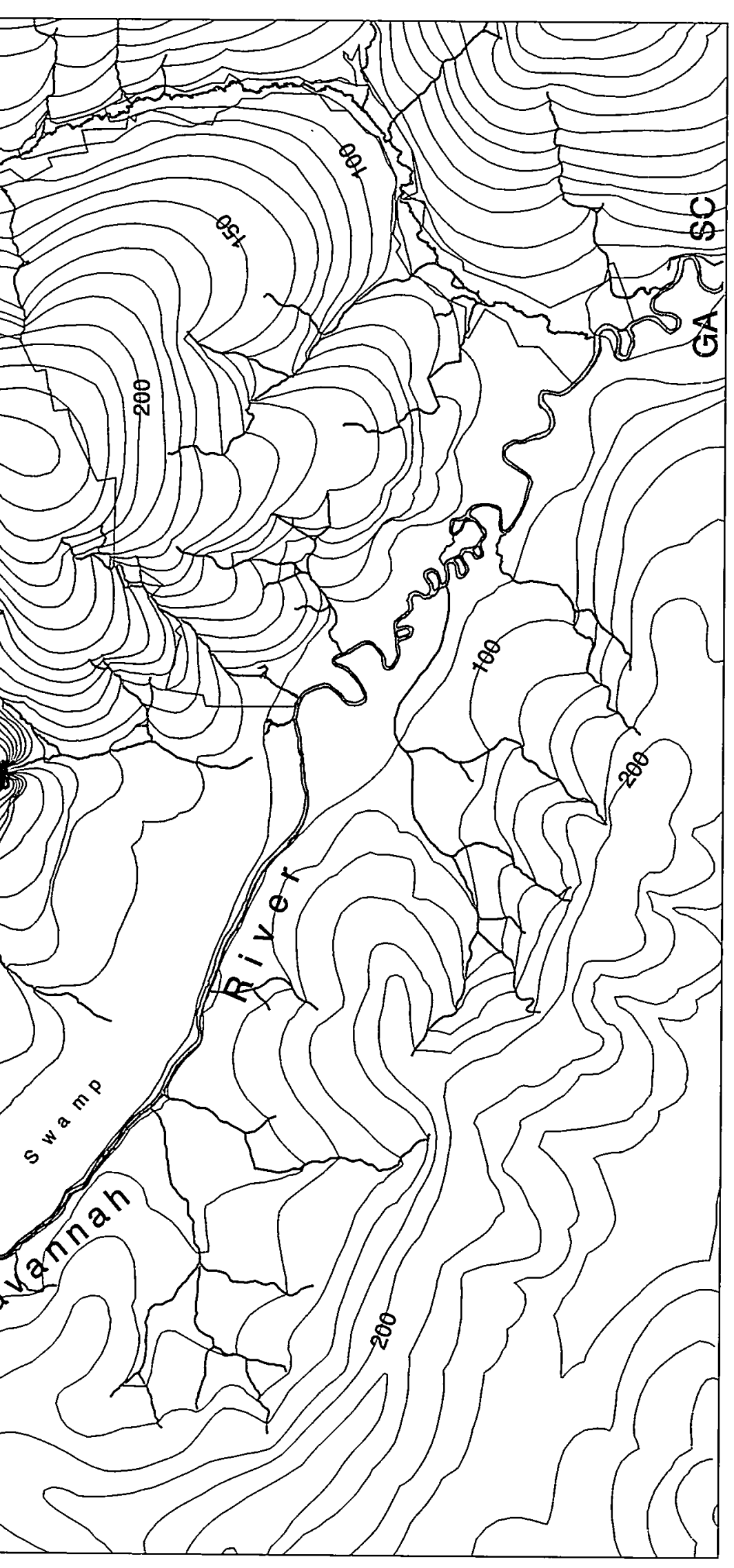

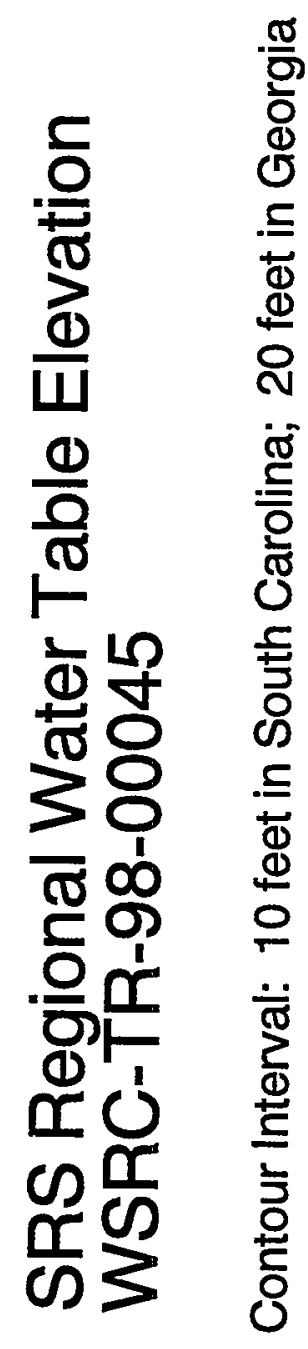

$\stackrel{\infty}{\Sigma}$

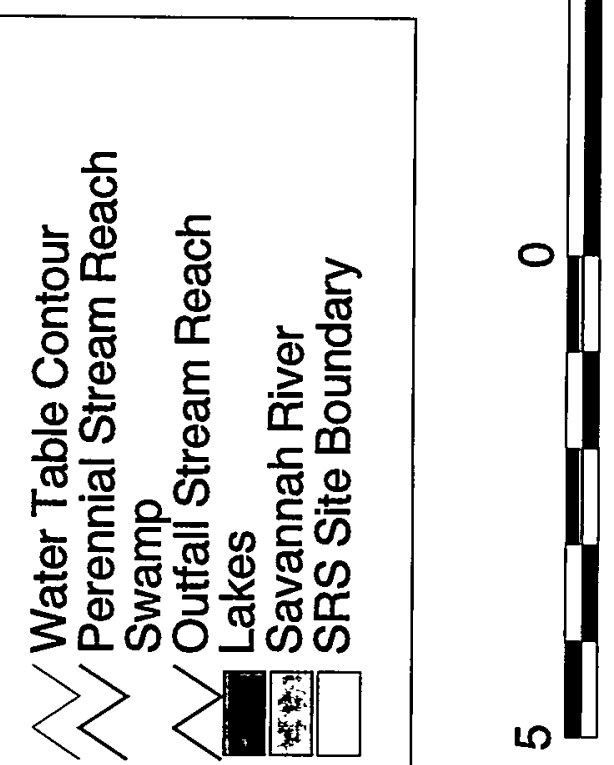


impoundments and along the canal system that connects them. Water levels in the lakes and canals are maintained at a constant elevation, hence the water table has reached a new equilibrium level near these locations.

\subsection{General Separations Area}

The configuration of the water table in the General Separations Area is illustrated in Figure 3. The general configuration shows a divide area running from west to east with a second divide extending north between McQueen Branch and Crouch Branch to Upper Three Runs Creek. North of the main divide, the water table slopes steeply toward Upper Three Runs Creek but is relatively flat in the flood plain of the creek. South of the divide, the water table slopes less steeply toward Four Mile Branch. The highest elevations occur just southeast of $\mathrm{H}$-Area, where the tip of the 280 -foot contour is observed. The lowest elevation is slightly less than 140 feet, at the point where Upper Three Runs exits the view.

There is a pump and treat groundwater remediation system in operation in the GSA. The effect of this system is not shown in Figure 3 due to the scale of the figure and the regional water table contour interval.

Numerous wells exist in the GSA and are widely distributed throughout the GSA, as shown in Figure 3. Water table contours have been made to be consistent with mean water level elevations obtained from the great majority of these wells. This configuration is highly similar to previous water table map configurations that utilized measurements from a single quarter. The large number of control points, and the widespread distribution of these points throughout the GSA, combine to provide a relative high degree of certainty in the elevation of the water table in the GSA.

\subsection{A/M Area}

The configuration of the water table in the $\mathrm{A} / \mathrm{M}$ Area is shown in Figure 4. The general configuration shows a divide that extends from the northeast corner to the south central part of the illustration. Groundwater flow is to the south and southwest beneath most of the A/M Areas, toward the Savannah River floodplain. The red lines depict the trace of the A-01 and A14 outfall drainage ways. They flow continuously due to surface discharge at the NPDES outfall stations, located at the upstream end of the red lines. Because these reaches are wet continuously they are areas of continuous infiltration. This infiltration becomes groundwater recharge, resulting in a mounding in the water table beneath them. The loss of water along the "red" reaches has been confirmed in the A- 014 outfall reach with surface flow measurements (WSRCOS-97-00004). The available well measurements also appear to be consistent with the interpretation of groundwater mounding at these locations, and suggest the contour " $V$ ' $s$ " point in the downstream direction near the outfalls. Water table elevations range from over 250 feet in the area northeast of the A/M Areas, to 160 feet at the location where Tims Branch exits the view on Figure 4.

There is a pump and treat groundwater remediation system in operation in the $\mathrm{A} / \mathrm{M}$ Area which induces downward movement of groundwater from the water table to the underlying aquifer near the contamination waste sites in the A/M Area. However, at the scale of this figure, and because of the 10-foot contour interval, the effects of this system are not shown on Figure 4.

Numerous wells are located within the $\mathrm{A} / \mathrm{M}$ Area and are widely distributed throughout the area, as shown on Figure 4. Water table contours have been made to be consistent with mean water level elevations obtained from the great majority of. these wells. The large number of control points and their distribution throughout the $\mathrm{A} / \mathrm{M}$ Area combine to provide a relative high degree of certainty in the elevation of the water table in the A/M Area. 
Figure 3 General Separations Area Water Table Elevation

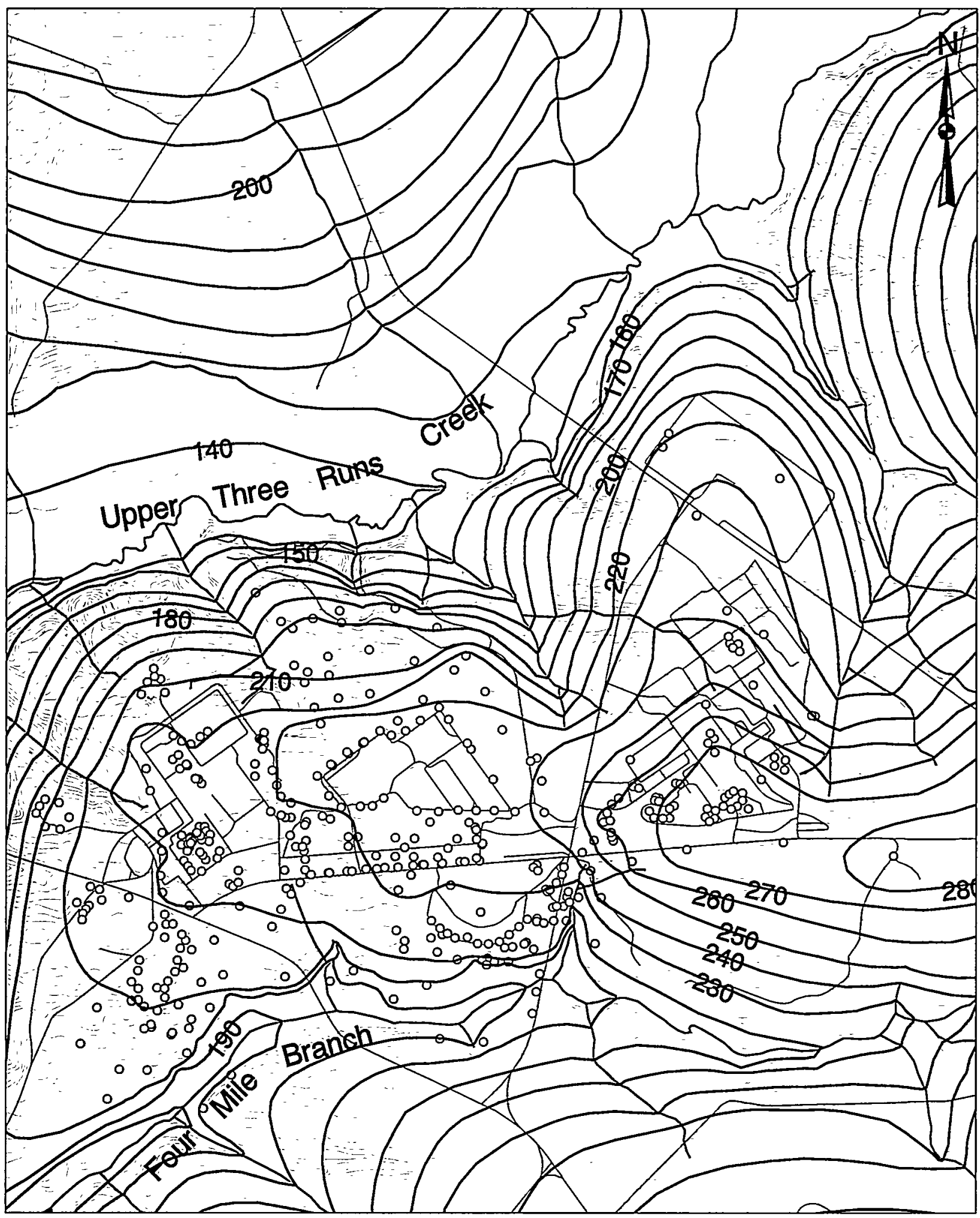

Water Table Contour O Water Table Well Perennial Stream Reach Outtall Stream Reach $\checkmark$ Roads Land Surface
General Separatios Area Water Table Elevation WSRC-TR-98-00045

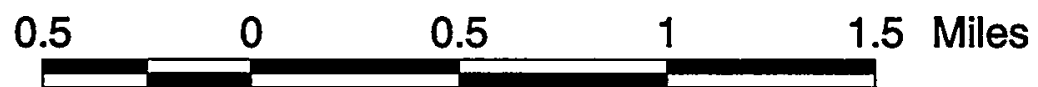


Figure 4. A/M Area Water Table Elevation
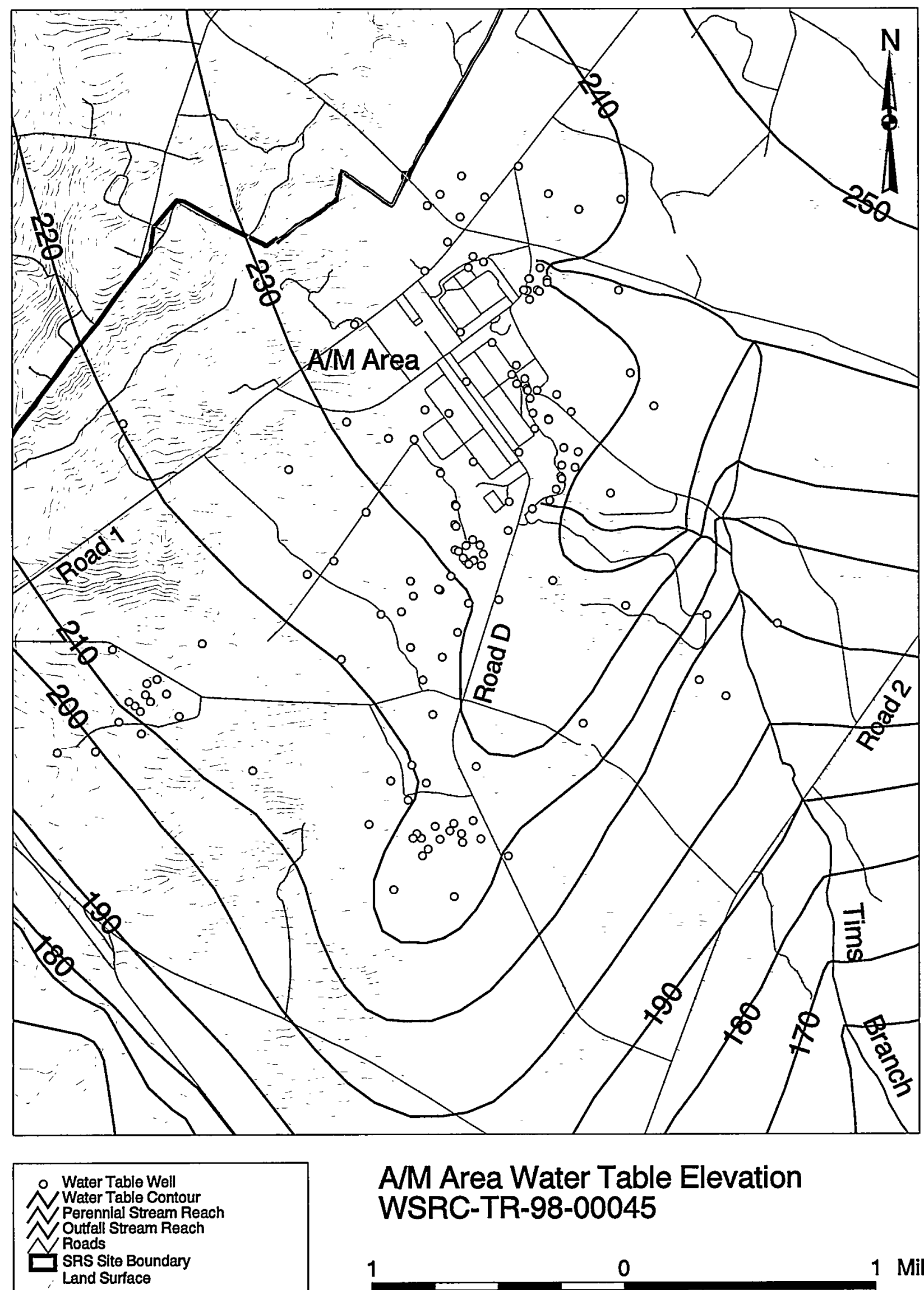

A/M Area Water Table Elevation
WSRC-TR-98-00045

1

0

1 Miles 


\subsection{D-Area / TNX}

The configuration of the water table in the DArea/TNX Area is shown in Figure 5. The general configuration shows that groundwater generally moves from northeast to southwest, toward the Savannah River floodplain. A groundwater divide does extend from northeast to southwest between Upper Three Runs Creek and Four Mile Branch, however the dominant direction of groundwater movement is in the direction indicated. Water table elevations range from approximately 150 feet, northeast of DArea, to approximately 85 feet where groundwater discharges into the Savannah River.

Clusters of wells exist in both the D-Area and TNX, providing a high degree of certainty in water table elevations near these locations. Overall, the level of certainty in water table elevation is regarded as moderate to high in this area. The effects of the TNX groundwater remediation system are not shown due to the scale of the figure and the regional contour interval.

\subsection{B-Area}

The configuration of the water table near B-Area is shown in Figure 6. The general configuration shows a divide that extends from the north to south and running just west of the B-Area. East of the divide groundwater generally moves east and southeast toward Upper Three Runs Creek. West of the divide, groundwater moves southwest toward the floodplain of the Savannah River. Water table elevations range from approximately 200 feet, just northwest and just southeast of BArea, to approximately 110 feet along Upper Three Runs Creek.

A small mounded area in the water table is shown just south of B-Area and is confirmed by mean water levels obtained from several wells. There is some uncertainty in the water levels immediately west of B-Area, where the mean water levels from two wells are approximately 20 -feet lower than surrounding wells. The contours of the water table elevation in this area has been made to be consistent with the most reasonable interpretation of the data, and some additional work may be required to determine why anomalous water levels have been obtained from the two well.

The large number of wells located just east of BArea monitor the Sanitary Landfill. These wells tend to provide a relatively high degree of certainty in the water table elevation near that facility. A clay cap has now been placed over most of the Sanitary Landfill, which could have slight impact on the configuration of the water table in the immediate area. Some wells located within the area of cap placement had their casing extended upward approximately 2-feet. Water level elevations obtained from these wells may be in error because the TOC reference elevation does not appear to have been updated. This level of impact is not reflected in the regional map because of the 10-foot contour interval used for that surface. Overall, the level of certainty of water table elevation in other parts of B-Area is regarded as moderate.

\subsection{Central Shops / C-Area}

The configuration of the water table near Central Shops / C-Area is shown in Figure 7. The general configuration shows a divide that extends from east to west, running beneath both areas, and partitioning groundwater flow north to Four Mile Branch and south to Pen Branch. The effect of tributaries to Four Mile Branch on the interpretation of the water table elevation can be seen in the areas north and south of C-Area. Water table elevations range from 280 feet, east of Central Shops, to approximately 180 feet along Four Mile Branch and Pen Branch

A moderate number of wells exist in these areas and are widely distributed. The well measurements coupled with land elevations near flowing stream reached provide adequate control, although some data gaps exist south of the two areas, near the divide extensions. Overall, the level of certainty with which the water table 
Figure 5 TNX / D-Area Water Table Elevation

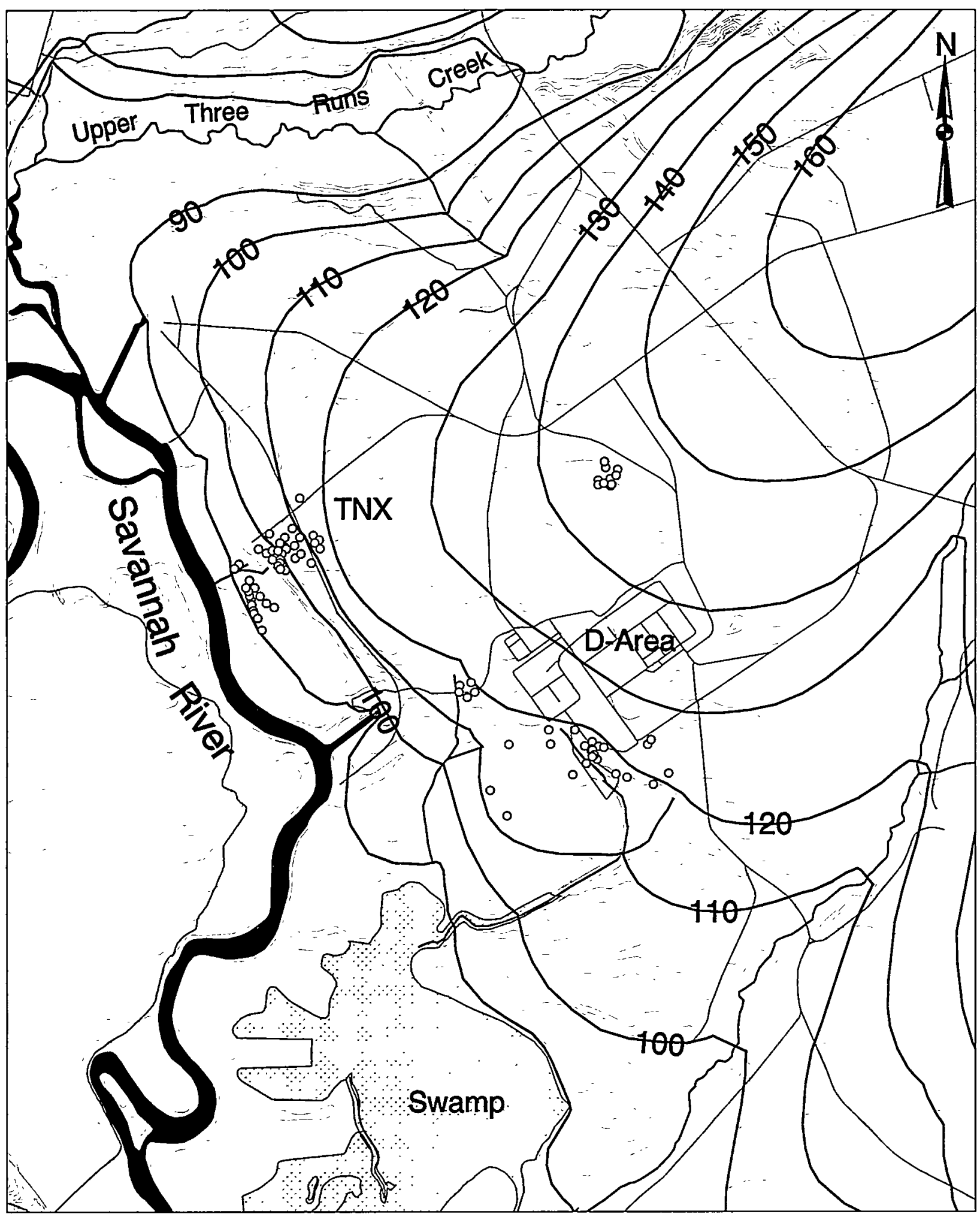

- Water Table Well

Water Table Contour

Perennial Stream Reach

Outfall Stream Reach

Roads

Savannah River

Swamp

Land Surface
TNX / D-Area Water Table Elevation WSRC-TR-98-00045

0

1 Miles 
Figure 6 B-Area Water Table Elevation

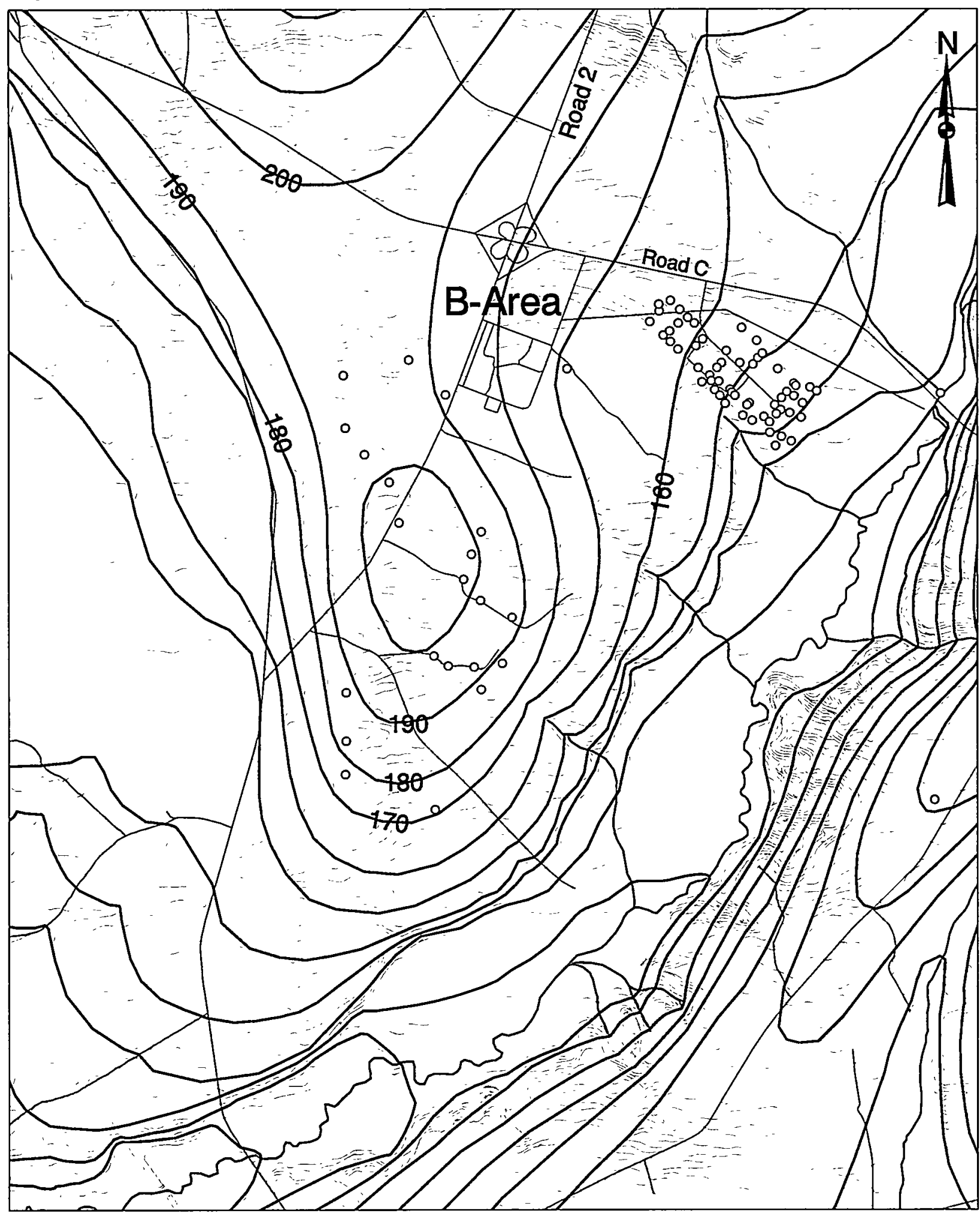

- Water Table Well

Water Table Contour

$\checkmark$ Perennial Stream Reach

Roads

Land Surface
B-Area Water Table Elevation WSRC-TR-98-00045

$\begin{array}{lllll}0.5 & 0 & 0.5 & 1 & 1.5 \text { Miles }\end{array}$ 
Figure 7 C-Area / Central Shops Water Table Elevation

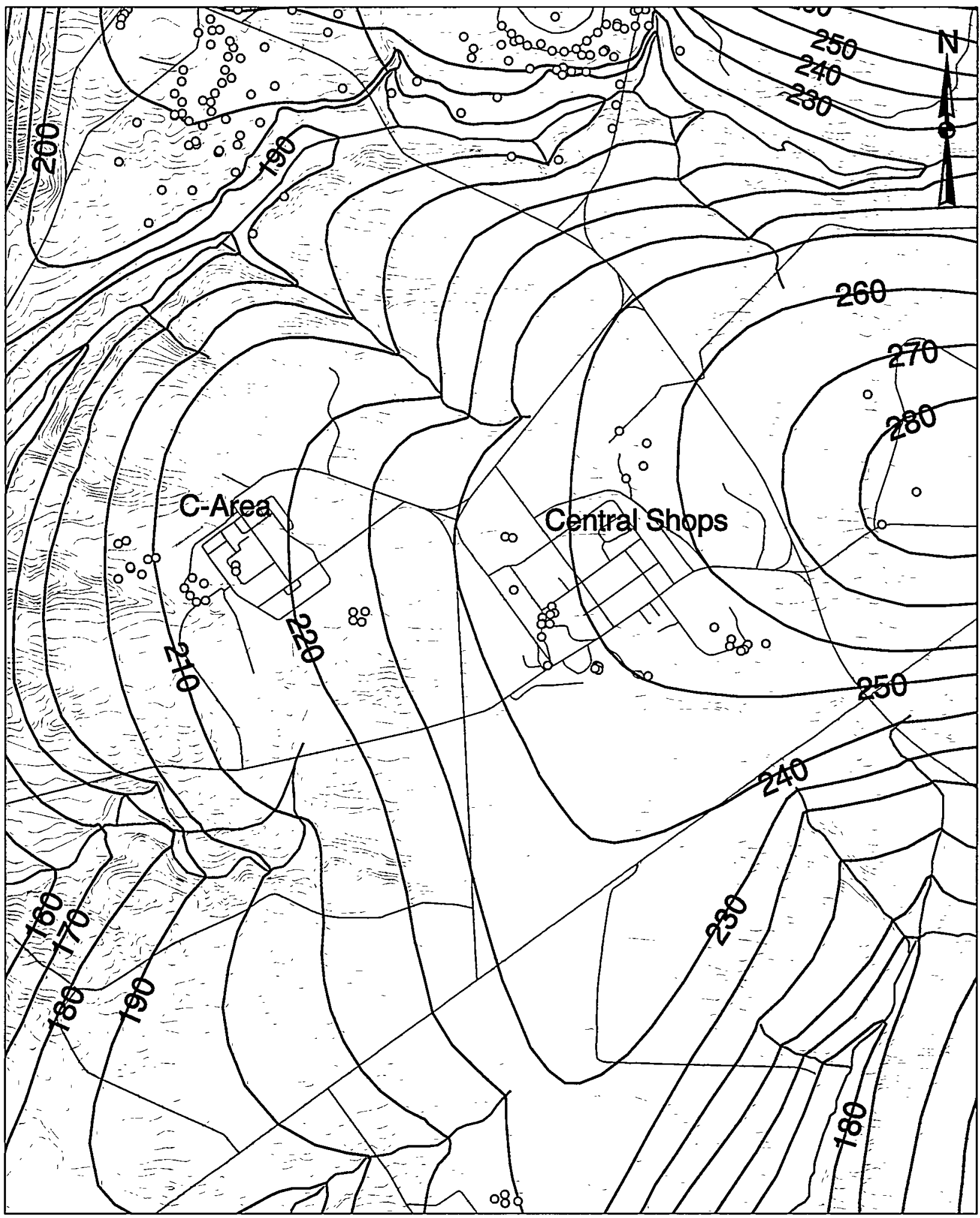

- Water Table Well

Water Table Contour

Perennial Stream Reach

Outfall Stream Reach

Roads

Land Surface
C-Area / Central Shops WaterTable Elevation WSRC-TR-98-00045

$\begin{array}{lllll}0.5 & 0 & 0.5 & 1 & 1.5 \text { Miles }\end{array}$ 
elevation is known in vicinity of the Central Shops / C-Area is moderate.

\subsection{R-Area}

The configuration of the water table in the RArea is shown in Figure 8. The general configuration shows a mounded area, centered on the R-Area, with flow radiating outward. To the north groundwater flows toward discharge points along Mill Creek, to the north and northeast flow proceeds to discharge areas along a stream that runs into Par Pond, and to the southeast toward Par Pond, itself. Water table elevations range from 300 feet, just west of R-Area, to 280 feet along the R-Canal turnout drainage way. The mounded groundwater near R-Area is suspected of reflecting perched conditions. Evidence to suggest perching include geologic logs, shallow water levels that have a somewhat higher degree of variability associated with the occurrence or absence of recharge events, and the preliminary results of a groundwater flow model that has been developed to simulate groundwater movement near R-Area.

In the vicinity of R-Area, a canal was constructed for diverting cooling water to $\mathrm{Par}$ Pond. The canal no-longer receives discharge, however water stands in the bottom of the canal over its entire length. Groundwater seeps into the canal from the north and west sides and seeps out along the east and south sides, hence it is a "flowthrough" type hydrologic feature from a groundwater standpoint. Water in the canal moves slowly from near the R-Area toward Pond $A$, Pond $B$ and discharges into Par Pond.

There are a moderate number of wells located at R-Area but their distribution tends to be clustered just north of R-Area, in the vicinity of a capped basin. As a result the certainty with which the elevation of the water table is known is moderate near R-Area.

\subsection{P-Area}

The configuration of the water table in the $\mathrm{P}$ Area is shown in Figure 9. The general configuration shows a divide that extends from the northwest to southeast, partitioning flow between Steel Creek to the southwest and tributaries of Lower Three Runs to the northeast. A groundwater mound area exists beneath $P$. Area and flow radiates outward in all directions except to the northwest. Water table elevations range from just over 280 feet, beneath P-Area, to approximately 220 along the tributary to Lower Three Runs.

Only a few wells are clustered around individual waste sites at P-Area and much of the control for water table elevation is derived from flowing stream reaches. As a result the certainty with which water table elevation is known is moderate near P-Area.

\section{$4.9 \quad$ K-Area}

The configuration of the water table in the KArea is shown in Figure 10. The general configuration shows a divide that extends from the north to south, dividing groundwater movement toward discharge zones along Indian Grave Branch and Pen Branch. Groundwater movement is to the south and southwest beneath most of the K-Area. An NPDES outfall is located just to the west of $\mathrm{K}$-Area, and a prominent discharge ditch has been excavated between the outfall point and Indian Grave Branch. The outfall ditch is continuously wet and loses water to the subsurface along its length. As a result, groundwater is shown to mound slightly beneath the ditch, although there are no wells located to confirm this interpretation. The water table contours in the vicinity of the outfall reach have "V's" that point in the downstream direction.

Water table elevations range from 230 feet, north of K-Area, to 140 feet near the confluence of Indian Grave Branch and Pen Branch.

There are a moderate number of wells located at $\mathrm{K}$-Area and their distribution is fairly widespread. As a result the certainty with which 
Figure 8 R-Area Water Table Elevation

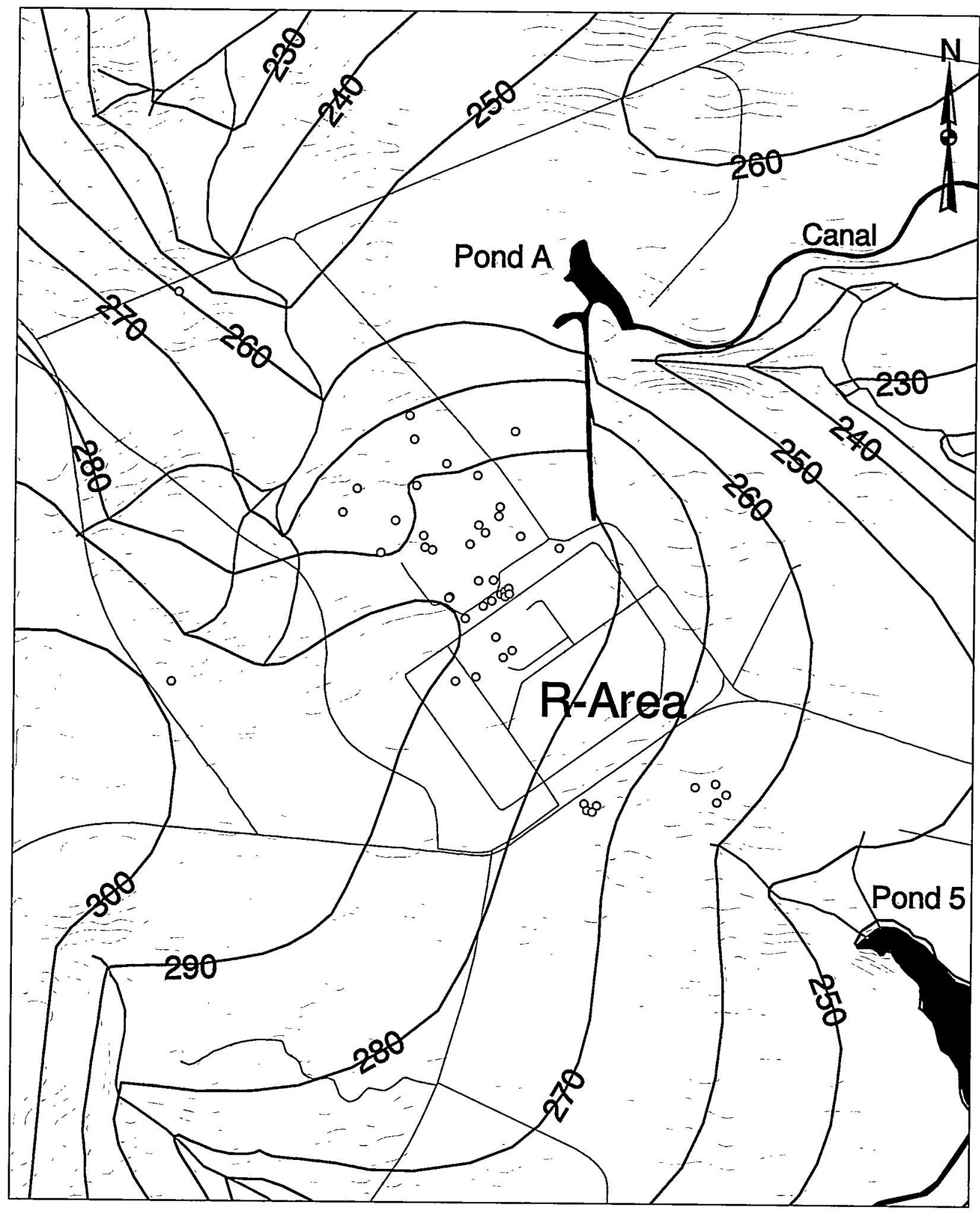

- Water Table Well

Water Table Contour

Perennial Stream Reach

Roads

Lakes

Land Surface
R-Area Water Table Elevation WSRC-TR-98-00045

0.5

0.5 Miles 
Figure 9 P-Area Water Table Elevation
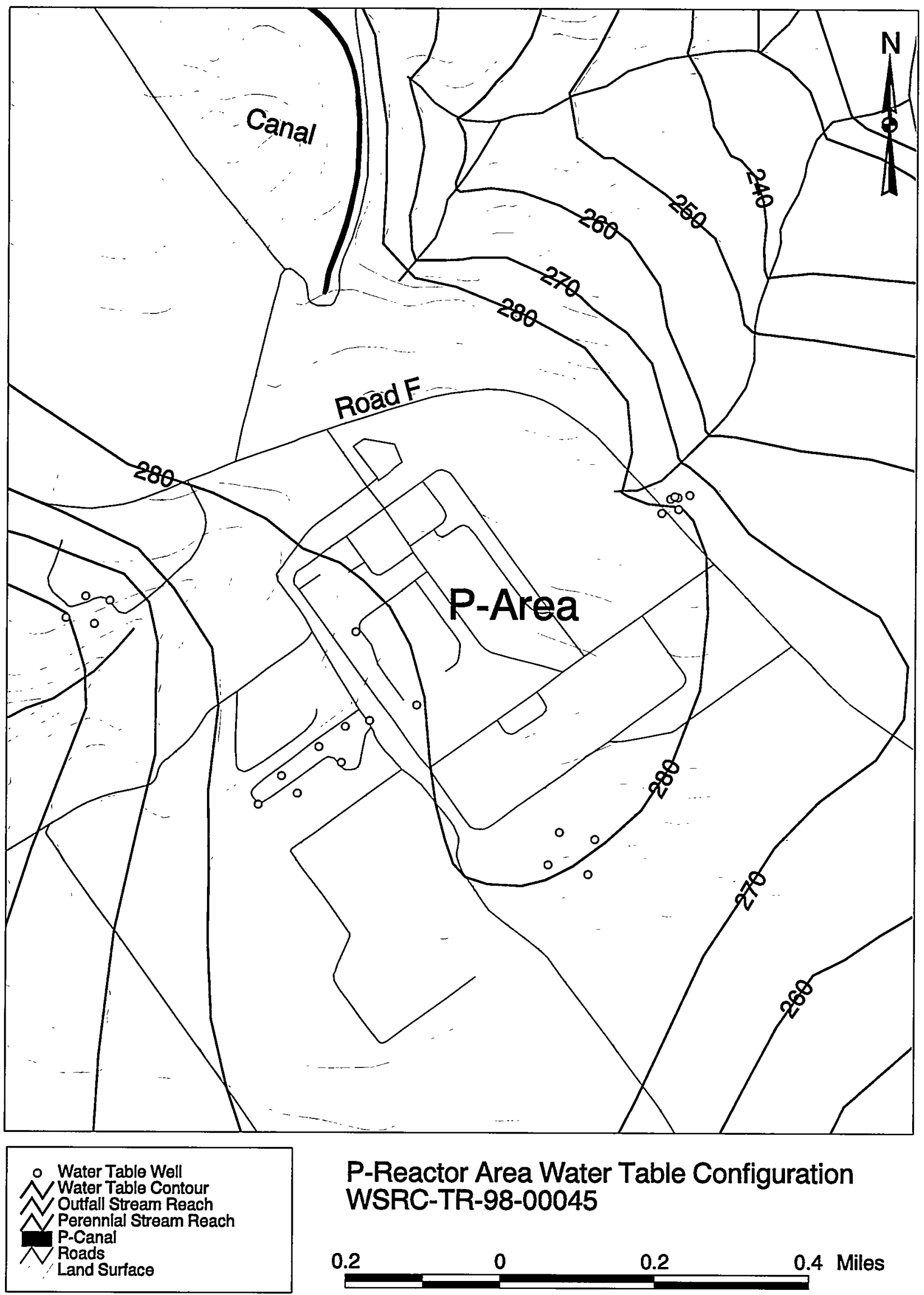

P-Reactor Area Water Table Configuration WSRC-TR-98-00045

0.2

0

0.2

0.4 Miles 
Figure 10 K-Area Water Table Elevation

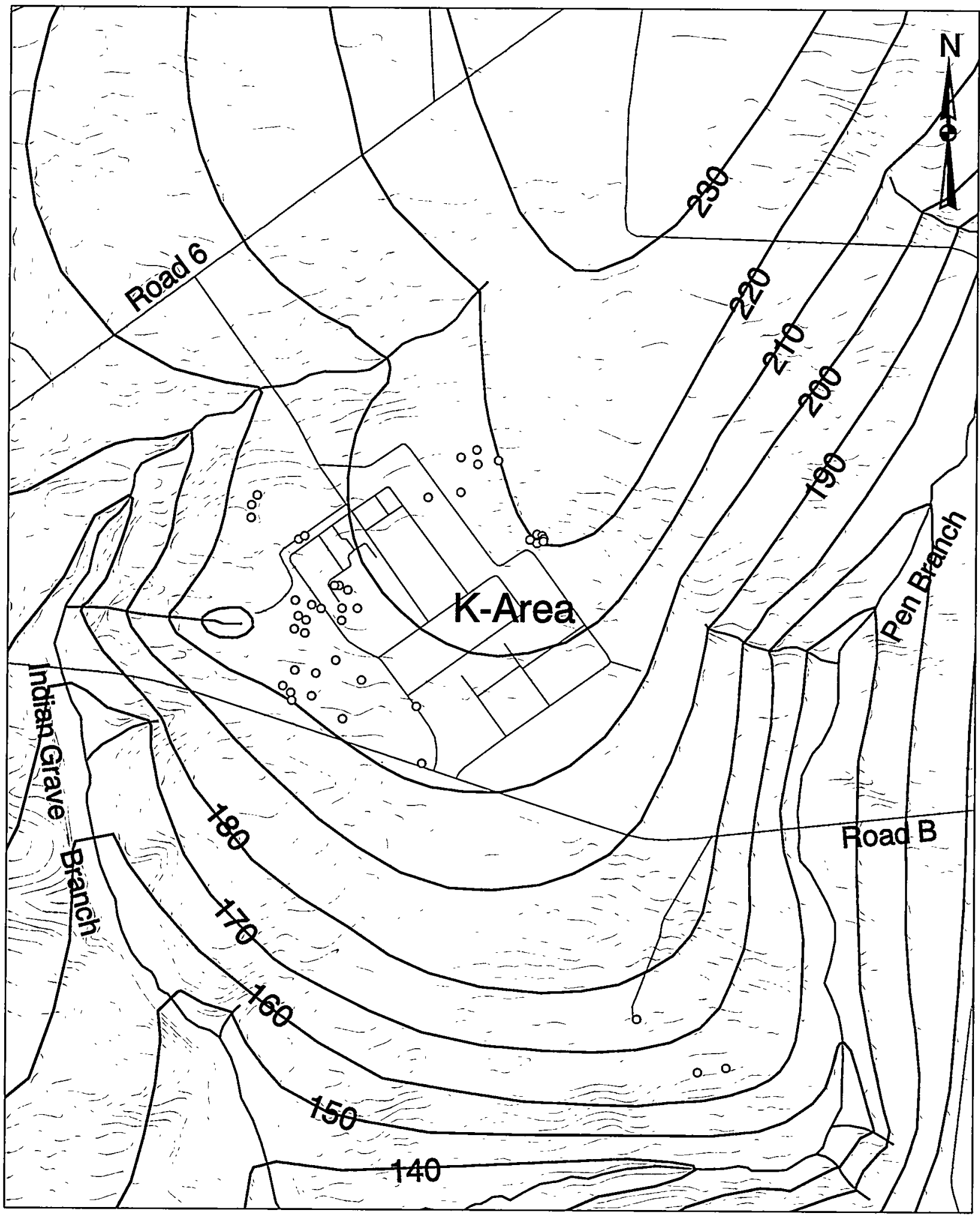

- Water Table Well

NWater Table Contour

Perennial Stream Reach

Outfall Stream Reach Roads

Land Surface

\section{K-Area Water Table Elevation} WSRC-TR-98-00045
0.25
0
0.25
0.5
0.75
1 Miles 
the elevation of the water table is known at $\mathrm{K}$ Area is moderate to high.

\subsection{L-Area}

The configuration of the water table in the LArea is shown in Figure 11. The general configuration shows a divide that extends from the northeast corner to the south central part of the illustration. The divide separates groundwater moving toward Pen Branch, to the north, and Steel Creek (and L-Lake) to the south.

Groundwater movement beneath L-Area is southward toward L-Lake. Water table elevations range from 250 feet, northeast of L-Area, to 190 feet along the banks of L-Lake.

There are a few wells clustered at waste disposal facilities in L-Area and some farther north near Pen Branch. Flowing stream reaches and wells provide sufficient control to allow water table elevations to be known with moderate certainty. 
Figure 11 L-Area Water Table Elevation

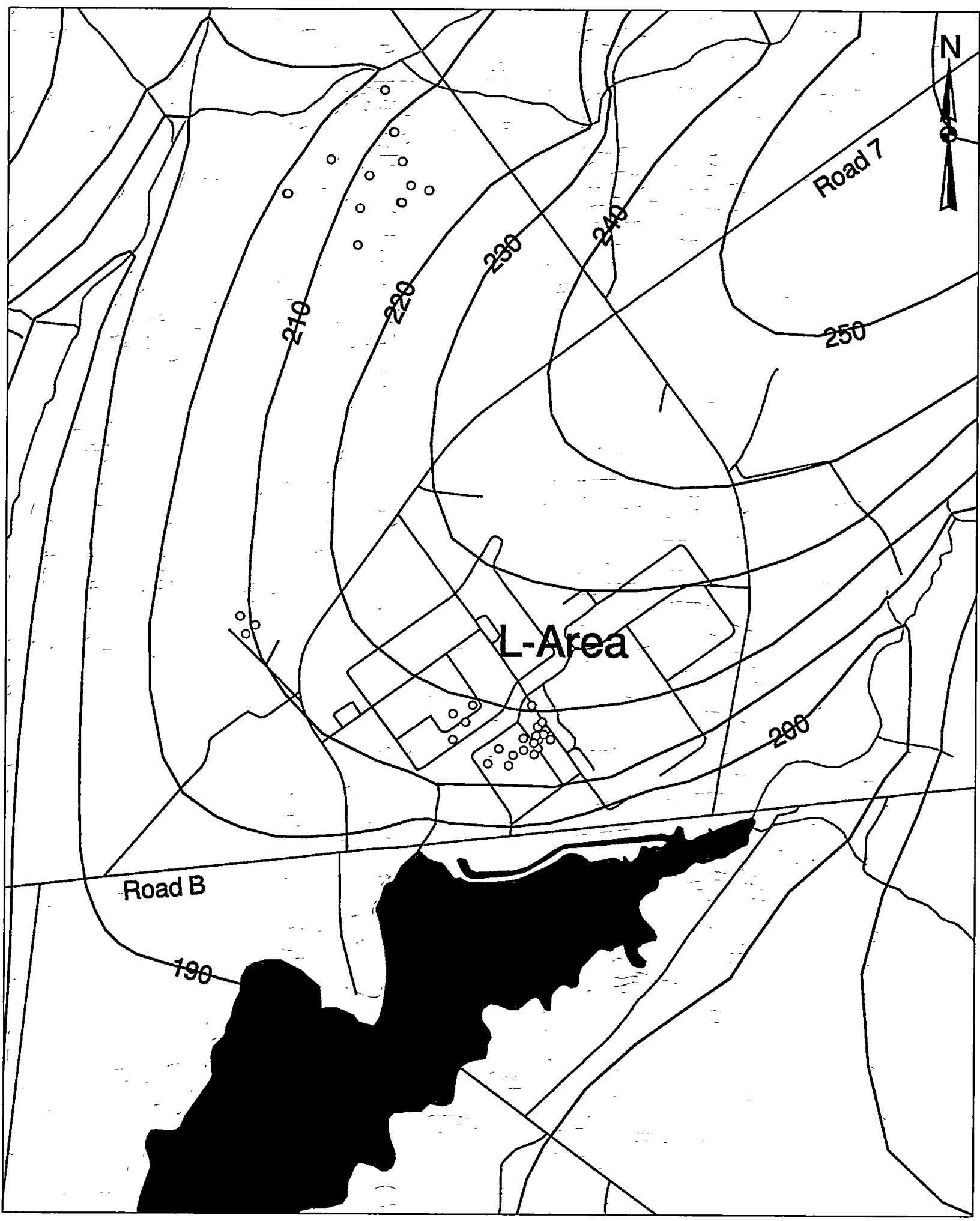

- Water Table Well

Water Table Contour

Perennial Stream Reach Outfall Stream Reach

Lakes

Roads

Land Surface
L-Reactor Area Water Table Elevation WSRC-TR-98-00045
0.2
0.2
0.4
$0.6 \quad 0.8$
1 Miles 


\subsection{RELATED HYDROLOGIC COVERAGES}

Three hydrologic coverages, in addition to the water table elevation maps, have been created. These are the perennial stream reaches, artificially flowing stream reaches and groundwater basin delineations.

\subsection{Perennial and artificial stream reaches}

The extent of continuously flowing, or perennial, stream reaches are shown in Figure 12. This coverage was created by digitizing the trace of all flowing stream reaches. The digitized lines were made to be co-incident with the continuously flowing stream reaches found on the USGS 7.5 minute quadrangle sheets for most reaches. However, the new coverage differs from the 7.5 minute quadrangle coverage in several ways. Primarily, the position of the point of effluence for a number of streams is different for some streams than what is depicted on the quadrangle sheets. Points of effluence were modified based upon an extensive field survey. Secondly, where the quadrangle sheets show wetlands along some stream reaches, the continuous stream line is discontinuous, terminating at each end of the wetland. The new coverage extends streams through such wetland areas. An example of where this was done is along the lower reaches of Tims Branch.

An additional coverage associated with perennial stream reaches is that of "artificially" flowing stream reaches. These are drainage ways flow continuously as a result discharges from SRS operations. These stream segments are shown as red lines, as opposed to the blue lines used to delineate natural perennial stream reaches.

\subsection{Groundwater basins}

Delineations of groundwater basins for each of the major drainage ways at SRS are illustrated in Figure 13. These basins are similar to the surface watershed basins associated with each stream, except that they represent the area where shallow groundwater drains laterally into each stream. Surface and groundwater basin boundaries are nearly coincident, but are not exactly the same. There are places where surface water runoff at some point $(x, y)$ may drain toward one site stream whereas any water infiltrating to the subsurface at that point would eventually discharge at a different stream.

Although most water infiltrating to the water table moves laterally and discharges to local streams, some moves downward into deeper aquifers. Those aquifers may discharge to different site streams than the shallower aquifer. One example is found in the General Separations Area where the water table aquifer discharges laterally to Four Mile Branch (south of the main divide). Some of the water recharging the water table aquifer eventually migrates downward to the Gordon Aquifer, which discharges to Upper Three Runs Creek.

The occurrence of one unusual groundwater / surface water relationship is worthy of being mentioned. Along the western edge of L-Lake water is seeping out of the lake and into the groundwater system. This groundwater moves directly toward Pen Branch, where it discharges. Along the western edge of L-Lake the impoundment has raised lake levels higher than the mound that existed between Pen Branch and Steel Creek prior to construction of the dam. As a result, water from the Steel Creek basin discharges directly into the Pen Branch basin. 


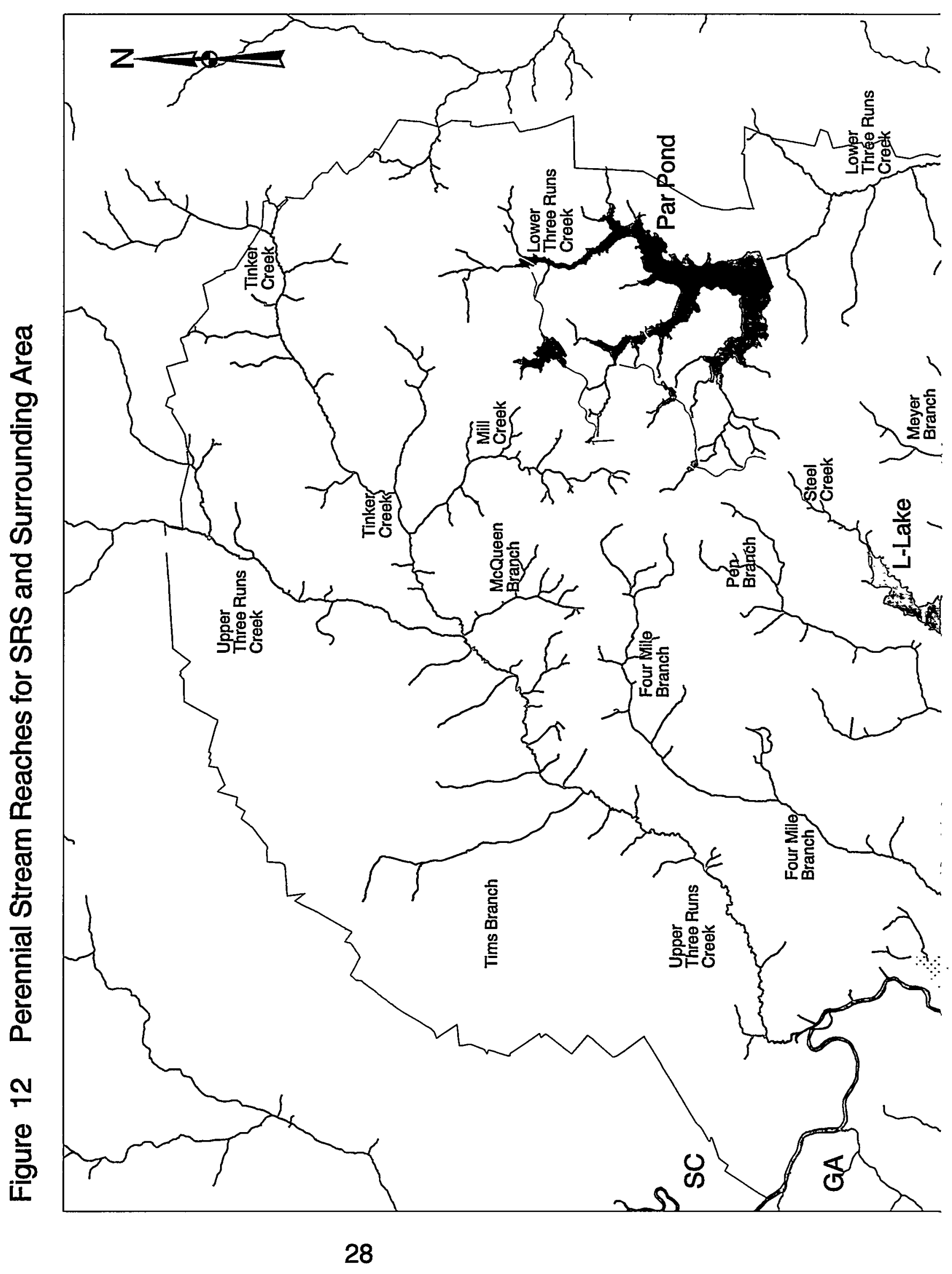




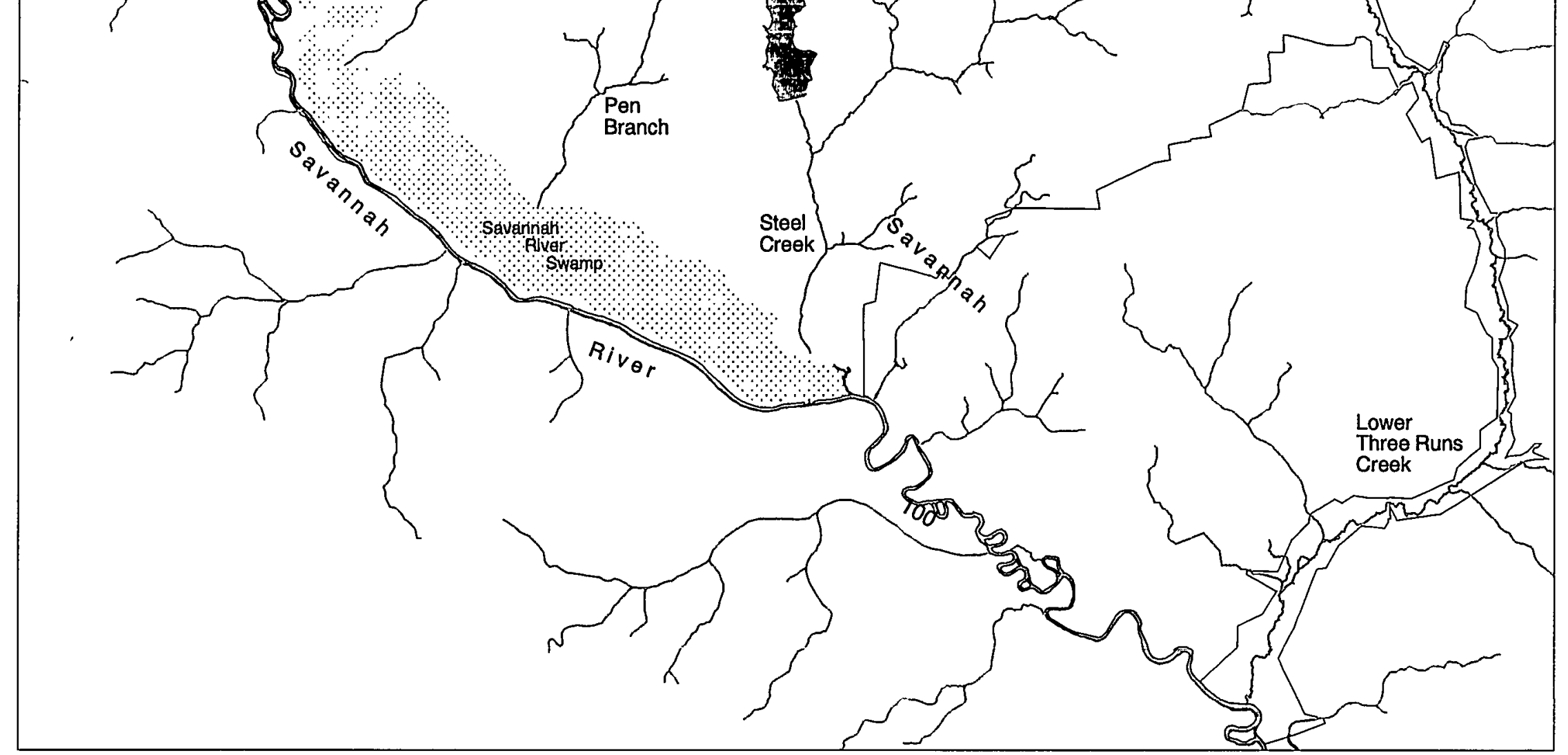

\section{Perennial Stream Reach Outfall Stream Reach Swamp \\ Lakes \\ Savannah River \\ SRS Site Boundary}

\section{Perennial Stream Reaches for SRS and} Surrounding Area WSRC-TR-98-00045

5 


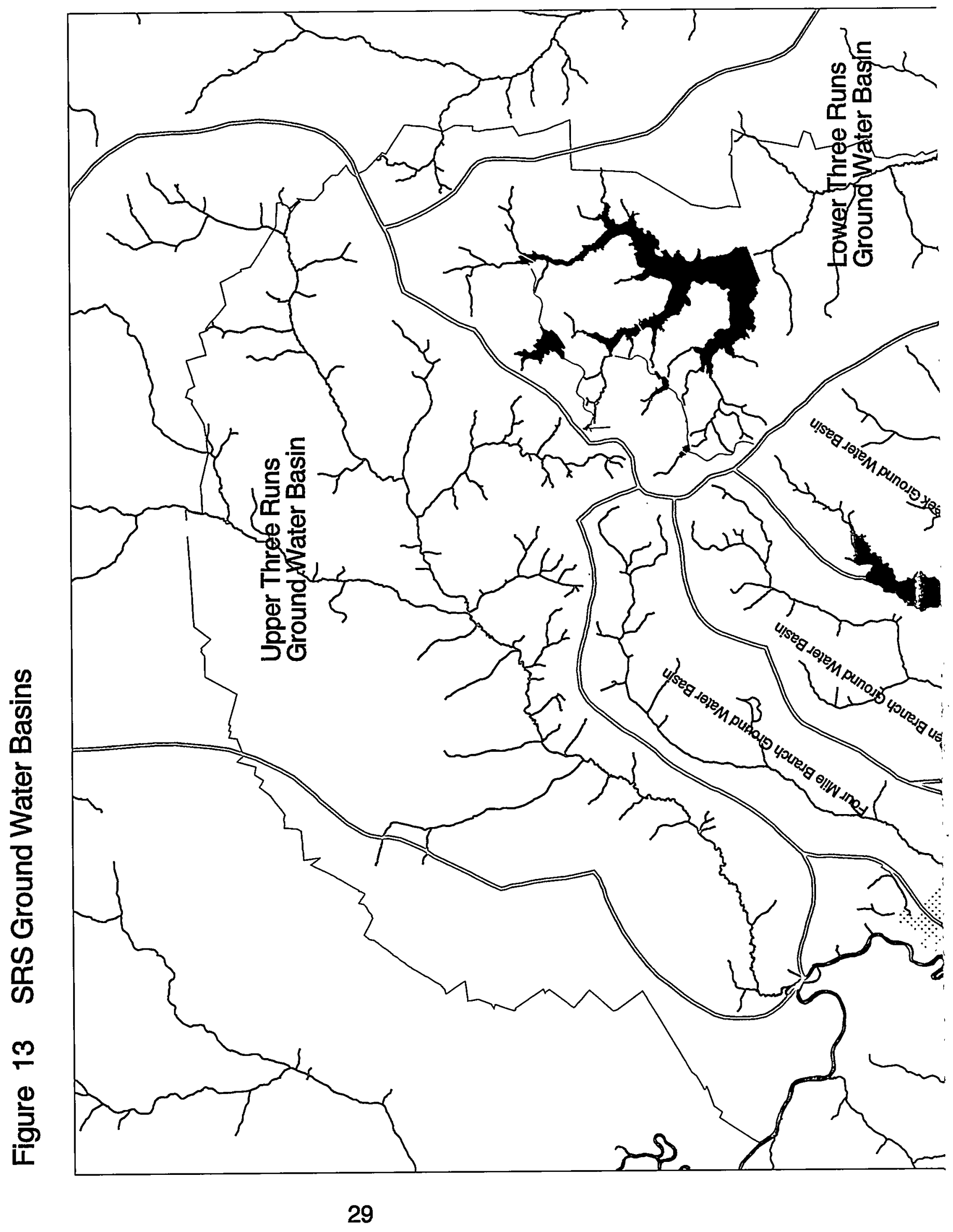




\subsection{AVAILABILITY OF COVERAGES}

All of the coverages mentioned in previous sections of this report were developed as ArcView shape files. It is anticipated that these coverages will be maintained and periodically updated, on an DEC Alpha workstation, known as Falcon, in Building 773-35. The workstation is operated by the Environmental Protection Department, Environmental Monitoring Section. Access can be obtained by contacting that organization to establish an account on Falcon. All ArcView coverages have been provided to the E\&GIS group and will be placed on the SRS Site Legacy $C D$ the next time the Legacy $C D$ is updated. Access can alternatively be obtained by acquiring one of these $C D s$.

It is expected that updates to this coverage will be attempted in the future. To assist in this endeavor any suggestions, criticisms, corrections or additions are requested to be provided to the author. 


\subsection{REFERENCES}

Bowers, J.A., J.B. Gladden, R.E. Osteen, C. Hopson, 1995, DataDelve and Eco Track Server: A Spatial Data System For Environmental Information, WSRC-RP-95-194, Westinghouse Savannah River Company, Aiken, SC, 29808.

Brewer, K.E., 1998, SGS Water Table Mapping Documentation. PECD-SGS-98-154, August 17, 1998.

DeMarsily, G., 1986, Quantitative Hydrogeology, Groundwater Hydrology for Engineers, Academic Press, Inc., Orlando, FL. 440 p.

Fetter, C.W., 1988, Applied Hydrogeology (2'nd Edition), Merrill Publishing Co., Columbus, Ohio, 592 p.

Freeze, R.A., and J.A. Cherry, 1979, Groundwater, Prentice-Hall, 604 p.

Freeze, R.A., and P.A. Witherspoon, 1967. Theoretical analysis of regional groundwater flow: 2 Effects of water table configuration and subsurface permeability variation, Water Resources Research 3, pp. 623634.

Hiergesell, R.A., 1994, Hydrologic Analysis of Data from the Lower Lost Lake Aquifer at Recovery Well RWM-12. WSRC-TR-93-666, Westinghouse Savannah River Company, Aiken, SC 29808.

Hiergesell, R.A., 1995, A regional water table map for the Savannah River Site, 1Q95, WSRC-MS-950524, Westinghouse Savannah River Company, Aiken, SC 29808.

Nichols. R. L. and J.S. Haselow, 1993. Potentiometric map of the Upper Three Runs/Steed Pond aquifers (Water table map), first quarter 1991. Figure contained in Hydrogeologic Framework of West-Central South Carolina, Aadland, R.K., J.A. Gellici, and P.A. Thayer, South Carolina Water Department of Water Resources, Water Resources Division Report 5.

WSRC-OS-97-00004, Tim's Branch Drainage Area Stream Flow and Analysis Study, E.I. du Pont de Nemours \& Company, Inc., Savannah River Plant, Aiken, SC. 


\section{APPENDIX}




\begin{tabular}{|c|c|c|c|c|c|c|c|c|c|c|c|c|}
\hline Well 10 & UTMN & UTME & Sz top & Sz bot. & Gr. Elev. & No. & Max. & Min. & Range & Std. Dev. & \begin{tabular}{|l} 
Mean WL \\
\end{tabular} & StdEr_Mean \\
\hline$A B P$ IDD & 3686140.3 & 431186.8 & 227.2 & 207.2 & 357.9 & 15 & 230.9 & 223.0 & 7.9 & 2.11 & 226.4 & 0.54 \\
\hline$A B P 2 D D$ & 3686144.8 & 4310678 & 2223 & 202.2 & 368.3 & 15 & 225.4 & 220.6 & 4.9 & 1.66 & 222.8 & 0.43 \\
\hline$A B P 3$ & 3686223.5 & 431154.8 & 236.9 & 206.9 & 351.9 & 42 & 227.7 & 218.0 & 9.7 & 284 & 223.4 & 0.44 \\
\hline$A B P A D D$ & 3686076.8 & 4311078 & 2232 & 203.2 & 362.7 & 14 & 226.4 & 2214 & 50 & 1.64 & 224.0 & 0.44 \\
\hline$A B P 6 D$ & 3686173.8 & 431037.1 & 2224 & 202.4 & 363.0 & 15 & 224.9 & 220.5 & 44 & 1.45 & 2229 & 0.37 \\
\hline$A B P 7 D$ & 3686034.8 & 431073.8 & 225.2 & 205.2 & 361.9 & 14 & 226.4 & 221.2 & 5.2 & 1.56 & 224.0 & 0.42 \\
\hline$A B P B D$ & 3686144.3 & 431014.5 & 228.2 & 208.1 & 368.8 & 37 & 225.3 & 214.3 & 110 & 3.14 & 221.1 & 0.52 \\
\hline$A B P 9 D$ & 3685817.8 & 430889.5 & 2320 & 212.0 & 351.0 & 11 & 224.5 & 2220 & 2.5 & 0.72 & 223.7 & 0.22 \\
\hline$A B P 1 O D$ & 3686233.8 & 430731.5 & 226.8 & 206.9 & 351.4 & 13 & 218.3 & 216.0 & 2.3 & 0.67 & 217.4 & 0.19 \\
\hline$A C=2 B$ & 3688505.5 & 430222.9 & 236.4 & 216.4 & 342.8 & 36 & 229.2 & 225.3 & 3.8 & 0.94 & 227.7 & 0.16 \\
\hline$A C \quad 3 B$ & 36865828 & 429990.3 & 213.4 & 193.4 & 300.1 & 39 & 2221 & 207.8 & 14.2 & 2.54 & 2122 & 0.41 \\
\hline$A C B \quad 1 A$ & 3688643.3 & 431979.0 & 247.6 & 217.6 & 357.6 & 41 & 239.7 & 233.4 & 6.3 & 1.39 & 237.4 & 0.22 \\
\hline$A C B 2 A$ & 3688614.8 & 432071.9 & 237.8 & 207.8 & 347.8 & 41 & 244.5 & 234.3 & 10.2 & 1.95 & 238.6 & 0.30 \\
\hline$A C B \quad 3 A$ & 3688517.8 & 432049.1 & 236.3 & 206.3 & 346.3 & 42 & 241.2 & 236.2 & 5.0 & 1.5 & 239.2 & 0.23 \\
\hline$A C B \quad 4 A$ & 3688529.0 & 431966.5 & 241.7 & 211.7 & 356.7 & 41 & 240.3 & 234.6 & 5.7 & 1.5 & 238.4 & 0.23 \\
\hline$A M B$ & 3689033.3 & 431736.7 & 242.8 & 222.8 & 378.6 & 11 & 234.2 & 230.3 & 3.9 & 1.29 & 232.3 & 0.39 \\
\hline$A M B \quad 4 D$ & 3689042.0 & 431733.6 & 233.4 & 213.4 & 378.4 & 34 & 235.7 & 230.7 & 5.0 & 1.01 & 233.4 & 0.17 \\
\hline AMB 5 & 3689020.5 & 431741.0 & 242.1 & 222.1 & 377.6 & 44 & 235.8 & 230.6 & 5.2 & 1.2 & 233.8 & 0.18 \\
\hline$A M B 6$ & 3689003 & 431749.6 & 242.6 & 222.6 & 375.1 & 45 & 2356 & 228.2 & 7.4 & 1.57 & 233.4 & 0.23 \\
\hline$A M B$ & 3689008.5 & 431809.2 & 242.1 & 222.1 & 368.1 & 46 & 235.9 & 230.8 & 5.1 & 1.26 & 234.1 & 0.19 \\
\hline$A M B$ BD & 3688957.3 & 431762.0 & 240.8 & 220.8 & 367.8 & 43 & 235.6 & 231.4 & 4.2 & 1.2 & 233.7 & 0.18 \\
\hline$A M B 9 D$ & 36888613 & 431780.1 & 239.7 & 2197 & 365.7 & 42 & 236.0 & 231.3 & 4.7 & 1.37 & 233.7 & 0.21 \\
\hline AMB $10 D$ & 3688824.0 & 431879.9 & 239.4 & 219.4 & 363.4 & 42 & 237.6 & 231.8 & 5.8 & 1.53 & 235.3 & 0.24 \\
\hline$A M B 10 D D$ & 3688203 & 431882.6 & 358.6 & 338.6 & 363.6 & 38 & 359.7 & 357.4 & 2.3 & 0.67 & 358.9 & 0.11 \\
\hline$A M B 11 D$ & 3688869.8 & 432026.3 & 240.5 & 220.5 & 362.0 & 40 & 238.4 & 233.2 & 5.3 & 1.52 & 236.1 & 0.24 \\
\hline$A M B 12 D$ & 3688980.0 & 431934.3 & 239.4 & 219.4 & 367.8 & 42 & 236.7 & 232.2 & 4.6 & 1.36 & 234.7 & 0.21 \\
\hline$A M B 14 D$ & 3689049.5 & 431679.8 & 235.1 & 215.1 & 380.1 & 14 & 233.4 & 230.2 & 3.2 & 1.15 & 232.0 & 0.31 \\
\hline$A M B 15 D$ & 36891085 & 431645.7 & 236.2 & 216.2 & 381.2 & 13 & 2357 & 232.4 & 33 & 1.02 & 2346 & 0.28 \\
\hline AMB 16D & 3689082.5 & 431730.0 & 233.4 & 213.4 & 378.4 & 14 & 235.3 & 231.4 & 3.9 & 1.24 & 233.9 & 0.33 \\
\hline$A O B$ & 3688309.3 & 431888.9 & 248.5 & 218.5 & 338.5 & 45 & 238.2 & 233.0 & 5.2 & 1.39 & 236.0 & 0.21 \\
\hline$\triangle O B=2$ & 3688376.5 & 431930.0 & 250.2 & 220.2 & 343.2 & 43 & 243.3 & 227.3 & 16.0 & 2.71 & 236.3 & 0.41 \\
\hline$A O B 3$ & 3688456.8 & 431960.1 & 243.9 & 223.9 & 350.6 & 40 & 239.8 & 229.5 & 10.3 & 1.86 & 2377 & 0.29 \\
\hline ARP IA & 3686511.5 & 430872.8 & 223.0 & 193.0 & 353.0 & 22 & 228.6 & 215.2 & 13.3 & 275 & 217.6 & 0.59 \\
\hline APि 2 & 36866158 & 4310074 & 220.3 & 190.3 & 335.3 & 43 & 221.7 & 2126 & 9.1 & 2.53 & 218.4 & 0.39 \\
\hline ARP 3 & 3686502.0 & 431100.6 & 218.2 & 188.2 & 338.2 & 39 & 224.5 & 214.8 & 9.7 & 2.63 & 220.7 & 0.42 \\
\hline$A R P$ & 3686389.8 & 430982.9 & 227.8 & 197.8 & 346.8 & 36 & 221.7 & 214.8 & 69 & 1.93 & 218.9 & 0.32 \\
\hline ASB $1 A$ & 3689583.8 & 431763.2 & 247.2 & 217.2 & 347.2 & 33 & 248.0 & 236.4 & 117 & 2.67 & 238.1 & 0.46 \\
\hline ASB $2 A$ & 3689655 & 431809.8 & 246.9 & 216.9 & 346.9 & 22 & 238.7 & 235.4 & 3.3 & 0.94 & 237.3 & 0.20 \\
\hline ASB $2 A R$ & 3689635.8 & 431826.4 & 240.1 & 220.2 & 353.1 & 28 & 240.2 & 236.9 & 3.3 & 0.84 & 2390 & 0.16 \\
\hline$A S B$ & 36897105 & 431874.0 & 247.9 & 217.9 & 342.9 & 22 & 239.8 & 236.2 & 3.6 & 1.06 & 238.1 & 0.23 \\
\hline ASB $3 A A$ & 368699.0 & 431874.1 & 243.1 & 223.1 & 339.1 & 28 & 2406 & 2298 & 10.9 & 2.49 & 238.8 & 0.47 \\
\hline ASB 4 & 3689783.5 & 4318301 & 256.1 & 226.1 & 333.1 & 46 & 243.3 & 235.3 & 7.9 & 1.53 & 238.3 & 0.23 \\
\hline$A S B 5 A$ & 36897153 & 431762.4 & 247.9 & 217.9 & 342.9 & 22 & 237.7 & 234.8 & 29 & 0.89 & 236.5 & 0.19 \\
\hline ASB $5 A A$ & 36897170 & 431756.9 & 243.8 & 223.8 & 344.5 & 28 & 246.2 & 235.2 & 11.1 & 247 & 237.9 & 0.47 \\
\hline ASB 6 & 3689642.0 & 431746.9 & 243.9 & 223.9 & 348.4 & 1 & 238.2 & 238.2 & 0.0 & $\ldots$ & 238.2 & \\
\hline ASB $6 A$ & 3689639.5 & 431746.0 & 248.2 & 218.2 & 348.2 & 50 & 248.7 & 229.5 & 19.2 & 2.88 & 236.9 & 0.41 \\
\hline ASB 7 & 3689644.0 & 431724.0 & 231.3 & 2113 & 351.3 & 21 & 235.4 & 232.2 & 3.2 & 0.95 & 234.3 & 0.21 \\
\hline$A S B 9$ & 3689640.0 & 432330.0 & 236.4 & 216.4 & 306.4 & 41 & 243.2 & 230.6 & 12.6 & 2.23 & 240.9 & 0.35 \\
\hline BG 52 & 3682807.5 & 437792.7 & 243.8 & 223.8 & 287.6 & 21 & 231.8 & 227.0 & 4.8 & 1.35 & 229.1 & 0.29 \\
\hline BG 53 & 3682787.8 & 437637.5 & 234.7 & 214.7 & 283.8 & 5 & 227.6 & 226.9 & 0.7 & 0.29 & 227.3 & 0.13 \\
\hline$B G 54$ & 36826653 & 437634.8 & 235.2 & 215.2 & 275.3 & 23 & 231.0 & 225.2 & 58 & 1.56 & 2286 & 0.33 \\
\hline $6 G 55$ & 36625453 & 437631.8 & 234.9 & 214.9 & 274.8 & 22 & 2294 & 224.4 & 5.0 & 1.44 & 227.0 & 0.31 \\
\hline BG 56 & 3682447.3 & 437662.2 & 230.9 & 210.9 & 272.6 & 5 & 226.4 & 224.1 & 2.3 & 0.93 & 225.2 & 0.42 \\
\hline$B G 5$ & 36824570 & 4377824 & 234.6 & 214.6 & 270.9 & 5 & 2254 & 224.9 & 0.5 & 0.17 & 251 & 0.08 \\
\hline BG 58 & 3682467.0 & 4379043 & 238.2 & 218.2 & 276.1 & 5 & 228.0 & 226.2 & 18 & 0.81 & 227.1 & 0.36 \\
\hline BG 59 & 3682480.3 & 438025.0 & 237.7 & 217.7 & 280.9 & 20 & 233.7 & 227.3 & 6.4 & 2 & 229.8 & 0.45 \\
\hline$B G 60$ & 3682490.5 & 438146.3 & 235.5 & 215.5 & 273.6 & 20 & 234.5 & 228.0 & 6.5 & 1.88 & 230.8 & 0.42 \\
\hline BG61 & 3682505.5 & 4383279 & 245.0 & 2250 & 2725 & 20 & 236.0 & 226.5 & 9.5 & $2.31=$ & 232.6 & 0.52 \\
\hline BG 62 & 3682510.5 & 438388.4 & 242.5 & 222.5 & 270.5 & 6 & 236.0 & 231.6 & 4.4 & 1.61 & 232.9 & 0.66 \\
\hline$B G 63$ & 3682518.0 & 438511.0 & 244.2 & 224.2 & 2724 & 6 & 237.2 & 233.8 & 3.4 & 1.2 & 234.9 & 0.49 \\
\hline$B G 64$ & 3682528.3 & 438632.4 & 247.3 & 227.3 & 283.3 & 6 & 239.8 & 236.4 & 3.4 & 1.18 & 237.7 & 0.48 \\
\hline BG 65 & 3682538.3 & 438753.3 & 250.9 & 230.9 & 289.1 & 6 & 236.5 & 234.4 & 2.1 & 0.88 & 235.1 & 0.36 \\
\hline$B G 66$ & 3682643.8 & 438771.6 & 251.0 & 2310 & 294.3 & 5 & 234.5 & 233.0 & 1.5 & 0.56 & 233.9 & 0.25 \\
\hline$B G 67$ & 36827523 & 438729.4 & 244.7 & 224.7 & 2928 & 22 & 247.2 & 233.2 & 14.0 & 3.09 & 236.3 & 0.66 \\
\hline$B G 91$ & 3683531.8 & 437689.6 & 235.4 & 205.4 & 2709 & 17 & 221.8 & 215.6 & 6.2 & 194 & 218.6 & 0.47 \\
\hline$B G 92$ & 3683807.3 & 437556.3 & 227.2 & 197.2 & 2527 & 17 & 2120 & 1981 & 139 & 3.11 & 208.8 & 0.75 \\
\hline BG 93 & 3684091.5 & 437474.9 & 210.5 & 180.5 & 256.0 & 17 & 203.6 & 191.1 & 12.5 & 4.5 & 198.9 & 1.09 \\
\hline
\end{tabular}




\begin{tabular}{|c|c|c|c|c|c|c|c|c|c|c|c|c|}
\hline Well ID & UTMN & UTME & Sz top & Sz bot. & Gr. Elev. & No. & Max. & Min. & Range & Std. Dev. & Mean WL & StdErr_Mean \\
\hline BG 96 & 3684163.8 & 437850.9 & 207.2 & 177.2 & 242.7 & 17 & 200.7 & 187.5 & 13.2 & 2.87 & 197.7 & 0.70 \\
\hline BG 101 & 3684177.8 & 438209.7 & 191.4 & 661.4 & 228.9 & 15 & 197.3 & 194.0 & 3.3 & 1.03 & 195.6 & 0.27 \\
\hline$B G 103$ & 36840518 & 438480.4 & 199.5 & 69.5 & 237.0 & 15 & 202.7 & 198.3 & 44 & 1.32 & 199.8 & 0.34 \\
\hline BG 104 & 3683868.0 & 4386654 & 245.8 & 215.8 & 283.3 & 1 & 224.8 & 224.8 & 0.0 & - & 224.8 & \\
\hline$B G 108$ & 3683203.0 & 4391268 & 247.3 & 217.3 & 264.8 & 18 & 241.3 & 236.7 & 4.6 & 1.33 & 238.8 & 0.31 \\
\hline$B G 109$ & 3683054.3 & 439159.0 & 258.4 & 228.4 & 283.9 & 17 & 242.7 & 237.9 & 4.8 & 1.44 & 240.1 & 0.35 \\
\hline$B G 110$ & 3682851.0 & 4391756 & 254.3 & 224.3 & 291.8 & 17 & 245.8 & 238.6 & 7.2 & 2.09 & 241.2 & 0.51 \\
\hline $\mathrm{BG} 122$ & 3683692.5 & 437625.5 & 209.9 & 189.9 & 246.0 & 17 & 213.8 & 208.8 & 5.0 & 1.51 & 2112 & 0.37 \\
\hline $\mathrm{BGO} 10$ & 3682856.0 & 438984.2 & 245.0 & 225.0 & 293.0 & 43 & 2422 & 230.5 & 11.7 & 2.86 & 237.5 & 0.44 \\
\hline$B G O 20$ & 3683062.3 & 438845.5 & 238.9 & 2189 & 2949 & 45 & 240.8 & 235.5 & 5.3 & 1.24 & 2379 & 0.18 \\
\hline$B G O B D$ & 3683259.0 & 438702.2 & 247.6 & 227.6 & 290.8 & 28 & 237.7 & 233.3 & 4.5 & 0.93 & 235.2 & 0.18 \\
\hline$B G O 3 D R$ & 3683300.5 & 438676.0 & 2376 & 217.5 & 289.3 & 10 & 232.5 & 231.2 & 1.4 & 0.49 & 2320 & 0.15 \\
\hline $\mathrm{BGO} 4 \mathrm{D}$ & 3683454.8 & 438557.6 & 240.6 & 220.6 & 295.6 & 15 & 236.9 & 230.5 & 6.3 & 1.55 & 2316 & 0.40 \\
\hline BGO 5D & 36835320 & 438494.3 & 239.3 & 219.3 & 2942 & 37 & 2319 & 229.5 & 2.4 & 0.54 & 230.7 & 0.09 \\
\hline BGO 6D & 3683447.0 & 438372.3 & 237.2 & 217.2 & 283.2 & 43 & 232.6 & 230.2 & 2.5 & 0.52 & 231.4 & 0.08 \\
\hline BGO $7 D$ & 3683380.5 & 438277.5 & 240.2 & 220.2 & 285.2 & 38 & 236.6 & 227.5 & 9.2 & 1.68 & 232.5 & 0.27 \\
\hline BGO 8D & 3683350.3 & 438186.8 & 240.6 & 220.6 & 2856 & 38 & 236.9 & 230.7 & 6.2 & 1.52 & 2329 & 0.25 \\
\hline$B G O 9 D$ & 3683380.3 & 438112.6 & 229.2 & 209.2 & 2832 & 42 & 233.3 & 216.0 & 17.4 & 4.1 & 230.0 & 0.63 \\
\hline BGO $10 \mathrm{D}$ & 3683298.3 & 438003.4 & 250.5 & 230.5 & 299.5 & 5 & 232.8 & 231.7 & 1.1 & 0.47 & 232.2 & 0.21 \\
\hline BGO 10DR & 3683305.8 & 438014.0 & 238.3 & 2183 & 298.3 & 28 & 233.9 & 230.0 & 3.9 & 0.96 & 232.0 & 0.18 \\
\hline BGO $11 D$ & 36832300 & 437909.9 & 236.3 & 216.3 & 303.3 & 33 & 233.8 & 224.3 & 9.5 & 257 & 230.6 & 0.45 \\
\hline BGO $11 D R$ & 363240.8 & 4379018 & 233.0 & 2131 & 302.9 & 10 & 231.5 & 229.5 & 2.1 & 0.68 & 230.5 & 0.22 \\
\hline BGO $12 D$ & 3683154.8 & 437806.4 & 2378 & 217.8 & 311.8 & 33 & 234.1 & 2293 & 48 & 1.38 & 231.3 & 0.24 \\
\hline BGO $12 D R$ & 3683159.0 & 437797.1 & 232.8 & 2127 & 3113 & 10 & 220.6 & 218.6 & 20 & 0.76 & 219.8 & 0.24 \\
\hline BGO 13D & 3683084.8 & 437710.0 & 248.5 & 228.5 & 316.5 & 3 & 2307 & 229.5 & 1.3 & 064 & 230.1 & 0.37 \\
\hline$B G O 14 D R$ & 3682956.5 & 437784.2 & 238.1 & 218.1 & 298.2 & 32 & 232.9 & 228.6 & 4.3 & 1.16 & 230.9 & 0.21 \\
\hline BGO 150 & 3682833 & 437863.9 & 238.7 & 218.7 & 296.7 & 41 & 232.5 & 228.2 & 4.3 & 1.23 & 230.0 & 0.19 \\
\hline$B G O 16 D$ & 36828900 & 437988.2 & 237.3 & 217.3 & 302.3 & 42 & 233.5 & 229.3 & 4.1 & 1.06 & 2310 & 0.16 \\
\hline BGO 17OR & 3682890.5 & 438065.2 & 236.9 & 216.9 & 296.9 & 27 & 2413 & 229.1 & 12.2 & 2.14 & 2322 & 0.41 \\
\hline BGO 180 & 3682944.0 & 438140.8 & 239.6 & 219.6 & 292.6 & 41 & 234.3 & 230.5 & 3.8 & 0.97 & 232.1 & 0.15 \\
\hline BGO 20D & 3682859.0 & 438354.3 & 236.3 & 216.3 & 281.3 & 39 & 240.8 & 231.6 & 9.2 & 1.51 & 234.1 & 0.24 \\
\hline BGO 210 & 3682855.8 & 438491.3 & 237.7 & 217.7 & 283.0 & 45 & 237.1 & 232.5 & 4.5 & 1.05 & 234.7 & 0.16 \\
\hline BGO 22DR & 3682867.0 & 438619.1 & 239.2 & 219.2 & 284.2 & 18 & 238.7 & 235.9 & 2.8 & 0.74 & 237.0 & 0.17 \\
\hline BGO $23 \mathrm{D}$ & 3682863.5 & 438735.3 & 242.0 & 2220 & 287.0 & 42 & 238.2 & 234.1 & 4.1 & 0.97 & 235.9 & 0.15 \\
\hline$B G O 24 D$ & 3682862.8 & 438851.1 & 241.0 & 2210 & 291.0 & 41 & 238.9 & 235.2 & 3.8 & 0.91 & 236.7 & 0.14 \\
\hline$B G O 26 D$ & 36827700 & 437628.3 & 233.5 & 213.4 & 283.5 & 42 & 230.8 & 225.6 & 5.2 & 1.39 & 227.9 & 0.21 \\
\hline BGO $27 D$ & 3682598.8 & 437626.6 & 229.3 & 209.3 & 274.3 & 42 & 231.0 & 224.9 & 6.1 & 1.35 & 227.6 & 0.21 \\
\hline BGO 28D & 3682478.0 & 437630.8 & 230.1 & 210.1 & 275.1 & 41 & 229.9 & 223.4 & 64 & 1.34 & 226.3 & 0.21 \\
\hline BGO $29 D$ & 3682473.8 & 437498.7 & 228.5 & 208.5 & 263.5 & 30 & 229.5 & 224.1 & 5.4 & 1.21 & 226.4 & 0.22 \\
\hline BGO $30 D$ & 36824458 & 4376698 & 227.8 & 207.8 & 272.8 & 41 & 229.4 & 222.9 & 6.5 & 1.36 & 225.7 & 0.21 \\
\hline BGO31D & 3682457.3 & 437790.5 & 2311 & 211.1 & 2716 & 41 & 230.4 & 223.5 & 6.9 & 1.41 & 2266 & 0.22 \\
\hline$B G O 32 D$ & 3682467.0 & 4379374 & 234.5 & 214.5 & 279.5 & 42 & 2313 & 225.4 & 5.9 & 1.38 & 227.6 & 0.21 \\
\hline BGO 330 & 3682483.0 & 438093.4 & 233.1 & 213.1 & 278.1 & 40 & 234.9 & 220.3 & 44.6 & 2.35 & 230.2 & 0.37 \\
\hline BGO 340 & 3682493.5 & 438231.8 & 2327 & 212.7 & 272.7 & 40 & 237.2 & 230.0 & 7.2 & 163 & 232.9 & 0.26 \\
\hline BGO 35D & 3682508.8 & 438399.3 & 239.4 & 219.4 & 271.4 & 39 & 2448 & 227.4 & 17.4 & 2.51 & 234.7 & 0.40 \\
\hline BGO 360 & 3682518.5 & 438517.2 & 243.3 & 223.3 & 2733 & 41 & 241.0 & 225.2 & 15.8 & 2.45 & 236.8 & 0.38 \\
\hline BGO 37D & 3682528.8 & 438662.3 & 246.1 & 226.1 & 285.1 & 40 & 243.0 & 234.6 & 8.4 & 198 & 238.1 & 0.31 \\
\hline$B G O 38 D$ & 3682536.3 & 438756.5 & 242.3 & 2223 & 289.3 & 40 & 240.0 & 233.2 & 6.8 & 1.55 & 235.3 & 0.25 \\
\hline BGO 39D & 36826480 & 438778.3 & 244.7 & 2247 & 293.7 & 39 & 238.3 & 233.2 & 5.2 & 1.29 & 235.2 & 0.21 \\
\hline BGO 40D & 3682701.8 & 437535.9 & 226.5 & 216.6 & 286.4 & 30 & 224.9 & 2200 & 4.9 & 1.26 & 2226 & 0.23 \\
\hline$B G O 440$ & 3683444.5 & 438228.2 & 233.4 & 223.4 & 283.4 & 27 & 234.4 & 230.3 & 4.1 & 0.9 & 2327 & 0.17 \\
\hline BGO 45D & 3682625.5 & 437571.5 & 229.6 & 2096 & 276.6 & 30 & 2309 & 225.5 & 5.4 & 1.21 & 228.0 & 0.22 \\
\hline $\mathrm{BGO} 49 \mathrm{D}$ & 3682441.0 & 438313.8 & 238.5 & 218.5 & 269.5 & 28 & 238.8 & 231.6 & 7.2 & 1.53 & 2345 & 0.29 \\
\hline$B G O 50 D$ & 3682392.3 & 437599.5 & 228.0 & 2080 & 2540 & 29 & 2286 & 223.0 & 5.7 & 1.25 & 225.2 & 0.23 \\
\hline BGO51D & 3682785.0 & 438689.7 & 240.1 & 220.1 & 287.1 & 11 & 236.8 & 234.0 & 2.8 & 0.88 & 235.5 & 0.27 \\
\hline BGO 520 & 36827898 & 438437.8 & 239.4 & 219.4 & 282.1 & 11 & 2354 & 232.5 & 2.9 & 0.83 & 234.1 & 0.25 \\
\hline BGO 53D & 3682825.8 & 437742.3 & 245.3 & 225.3 & 289.0 & 10 & 230.8 & 228.3 & 2.5 & 0.72 & 229.6 & 0.23 \\
\hline $\mathrm{BGX} 1 \mathrm{D}$ & 3683582.3 & 438391.3 & 234.7 & 214.7 & 289.2 & 30 & 230.8 & 2287 & 2.1 & 0.53 & 229.8 & 0.10 \\
\hline $\mathrm{BGX} 3 \mathrm{D}$ & 3683622.8 & 4380496 & 2216 & 2016 & 289.1 & 31 & 217.6 & 203.6 & 13.9 & 2.38 & 2148 & 0.43 \\
\hline $\mathrm{BGX} 4 \mathrm{D}$ & 3683594.3 & 437846.4 & 223.8 & 203.8 & 288.8 & 31 & 218.5 & 213.0 & 5.6 & 1.42 & 2159 & 0.26 \\
\hline$B G \times 5 D$ & 3683741.5 & 437785.5 & 215.0 & 1950 & 283.0 & 31 & 2124 & 206.4 & 6.0 & 1.58 & 209.2 & 0.28 \\
\hline$B G X 6 D$ & 3683863.5 & 437778.1 & 211.0 & 1910 & 2750 & 31 & 209.9 & 203.5 & 6.5 & 1.61 & 205.9 & 0.29 \\
\hline$B G X 7 D$ & 3683908.5 & 438042.3 & 214.1 & 194.1 & 277.1 & 26 & 209.1 & 203.5 & 5.6 & 1.41 & 205.7 & 0.28 \\
\hline$B G X 8 D R$ & 3683834.3 & 438333.7 & 203.1 & 1831 & 276.1 & 27 & 208.3 & 203.9 & 4.4 & 1 & 205.5 & 0.19 \\
\hline BGX 9D & 36837773 & 438593.7 & 232.4 & 2124 & 277.4 & 31 & 228.3 & 225.1 & 3.1 & 0.67 & 226.9 & 0.12 \\
\hline BGX $10 D$ & 3683635.5 & 438788.6 & 236.2 & 216.2 & 274.8 & 30 & 227.7 & 218.6 & 9.1 & 2.01 & 225.5 & 0.37 \\
\hline$B G \times 11 D$ & 3683385.0 & 438901.5 & 236.7 & 216.7 & 273.8 & 25 & 238.1 & 233.8 & 4.3 & 1.05 & 235.6 & 0.21 \\
\hline$B G X 12 D$ & 3683182.5 & 439084.0 & 243.7 & 223.7 & 273.2 & 31 & 242.5 & 236.5 & 6.0 & 1.58 & 238.8 & 0.28 \\
\hline
\end{tabular}




\begin{tabular}{|c|c|c|c|c|c|c|c|c|c|c|c|c|}
\hline Well ID & UTMN & UTME & Sz top & Sz bot. & Gr. Elev. & No. & Max. & Min. & Range & Std.Dev. & Mean WL & StdEr_Mean \\
\hline BRD 1 & 3673161.5 & 434922.4 & 178.9 & 148.9 & 203.9 & 28 & 169.8 & 164.7 & 5.2 & 1.74 & 167.3 & 0.33 \\
\hline $\mathrm{BRD} 2$ & 3673233.0 & 434900.3 & 178.5 & 148.5 & 205.5 & 28 & 175.0 & 157.8 & 17.2 & 3.6 & 169.2 & 0.68 \\
\hline BAD 3 & 3673222.5 & 434976.3 & 188.5 & 158.5 & 218.5 & 10 & 170.8 & 169.5 & 1.3 & 0.44 & 170.0 & 0.14 \\
\hline BAD $5 D$ & 3673180.3 & 434899.2 & 168.4 & 148.4 & 2027 & 25 & 169.1 & 1629 & 6.2 & 1.84 & 166.8 & 0.37 \\
\hline BAR ID & 3682280.8 & 436315.8 & 220.4 & 200.4 & 293.8 & 21 & 220.4 & 213.1 & 7.3 & 2.11 & 217.2 & 0.46 \\
\hline $\mathrm{BRA} 2 \mathrm{D}$ & 3682246.5 & 436234.5 & 216.1 & 196.1 & 289.6 & 22 & 218.8 & 211.4 & 7.4 & 2.2 & 215.5 & 0.47 \\
\hline BAR 3D & 3682220.0 & 436215.1 & 217.1 & 197.1 & 289.5 & 23 & 218.6 & 211.2 & 7.3 & 2.06 & 215.2 & 0.43 \\
\hline BRAA $4 \mathrm{D}$ & 3682193.0 & 436197.5 & 218.7 & 198.7 & 290.0 & 21 & 218.2 & 210.9 & 7.3 & 2.06 & 215.1 & 0.45 \\
\hline BAA $5 D$ & 3682152.8 & 436190.8 & 222.1 & 2021 & 292.6 & 20 & 217.8 & 210.4 & 7.4 & 1.91 & 214.9 & 0.43 \\
\hline BRA $6 D$ & 3682298.0 & 436491.9 & 219.3 & 1994 & 294.3 & 7 & 219.8 & 205.3 & 14.5 & 6.88 & 213.7 & 260 \\
\hline$B A R=70$ & 3682349.5 & 436303.6 & 221.9 & 201.9 & 289.2 & 5 & 218.7 & 217.3 & 1.4 & 0.67 & 217.9 & 0.30 \\
\hline BRA $8 D A$ & 3682265.5 & 436159.0 & 219.0 & 204.0 & 277.4 & 3 & 214.7 & 214.0 & 0.7 & 0.33 & 214.3 & 0.19 \\
\hline CBA ID & 3678506.8 & 4399050 & 250.9 & 230.9 & 298.5 & 21 & 256.9 & 248.0 & 8.9 & 2.54 & 253.5 & 0.55 \\
\hline $\mathrm{CBA} 2 \mathrm{D}$ & 3678471.5 & 4398826 & 253.8 & 233.8 & 298.8 & 22 & 256.2 & 247.7 & 8.5 & 2.49 & 252.9 & 0.53 \\
\hline CBA 30 & 3678464.3 & 439862.6 & 254.1 & 234.1 & 299.6 & 22 & 256.2 & 247.7 & 8.5 & 2.51 & 253.0 & 0.54 \\
\hline CBR 40 & 3678508.5 & 4400116 & 253.3 & 233.2 & 293.4 & 8 & 256.5 & 241.8 & 14.7 & 4.76 & 245.1 & 1.68 \\
\hline CCB 1 & 3678697.5 & 437568.3 & 228.4 & 198.4 & 276.4 & 18 & 230.4 & 219.9 & 10.5 & 3.2 & 226.8 & 0.75 \\
\hline CCB 2 & 3678647.5 & 437568.2 & 228.6 & 198.6 & 268.6 & 28 & 228.6 & 215.5 & 13.1 & 4.59 & 222.5 & 0.87 \\
\hline $\mathrm{CCB} 3$ & 3678638.5 & 437617.3 & 235.6 & 205.6 & 265.6 & 26 & 230.2 & 219.0 & 11.2 & 3.79 & 225.4 & 0.74 \\
\hline CCB 4 & 3678700.3 & 437638.4 & 241.2 & 211.2 & 281.2 & 28 & 231.5 & 213.3 & 18.2 & 4.2 & 226.3 & 0.79 \\
\hline $\mathrm{CDB} 1$ & 3678975.0 & 436874.6 & 216.6 & 195.7 & 286.6 & 30 & 219.6 & 209.3 & 10.3 & 3.3 & 214.3 & 0.60 \\
\hline$C D B 2$ & 3678938.3 & 436875.7 & 216.1 & 195.1 & 286.1 & 29 & 224.0 & 209.9 & 14.1 & 3.39 & 215.5 & 0.63 \\
\hline CMP 8 & 3676860.8 & 441650.0 & 214.0 & 184.0 & 227.0 & 28 & 205.9 & 201.1 & 4.8 & 1.3 & 203.6 & 0.25 \\
\hline CMP 10 & 36764950 & 4418160 & 218.8 & 188.8 & 308.8 & 20 & 223.2 & 217.4 & 5.8 & 216 & 2203 & 0.48 \\
\hline CMP $10 D$ & 3676493.3 & 441812.6 & 229.6 & 209.6 & 309.3 & 4 & 2327 & 219.1 & 13.7 & 5.75 & 224.9 & 2.88 \\
\hline CMP 11 & 3676451.8 & 441709.6 & 215.2 & 185.2 & 309.2 & 23 & 216.1 & 208.5 & 7.6 & 2.44 & 212.3 & 0.51 \\
\hline CMP IID & 3676449.5 & 441713.6 & 230.3 & 209.9 & 309.1 & 3 & 224.0 & 220.3 & 3.7 & 1.97 & 222.6 & 1.14 \\
\hline $\mathrm{CMP} 12$ & 3676547.0 & 441594.4 & 223.6 & 193.6 & 281.6 & 25 & 213.9 & 204.4 & 9.5 & 2.7 & 210.5 & 0.54 \\
\hline CMP 13 & 3676600.3 & 441716.4 & 212.7 & 182.7 & 287.7 & 28 & 211.0 & 205.5 & 5.5 & 1.74 & 208.2 & 0.33 \\
\hline CMP $14 C$ & 3676480.8 & 441288.5 & 215.1 & 185.1 & 262.8 & 23 & 217.1 & 205.7 & 11.3 & 3.57 & 212.4 & 0.74 \\
\hline CMP 140 & 3676480.5 & 441292.4 & 224.5 & 2041 & 263.7 & 4 & 2177 & 216.1 & 17 & 0.74 & 217.0 & 0.37 \\
\hline смір 15с & 3676290.8 & 441550.6 & 250.6 & 220.6 & 275.5 & 17 & 245.3 & 234.3 & 11.0 & 2.78 & 239.9 & 0.67 \\
\hline CMP $16 C$ & 3676512.0 & 441746.8 & 235.6 & 215.6 & 315.7 & 4 & 224.7 & 222.6 & 2.1 & 0.94 & 223.5 & 0.47 \\
\hline CMP $30 D$ & 3676429.5 & 441560.8 & 231.6 & 211.6 & 287.6 & 4 & 223.4 & 222.0 & 1.4 & 0.57 & 222.8 & 0.29 \\
\hline CMP $31 C$ & 36766606.5 & 441451.8 & 207.9 & 197.9 & 252.9 & 4 & 211.8 & 210.2 & 1.6 & 0.69 & 211.2 & 0.35 \\
\hline CMP $32 \mathrm{C}$ & 36767078 & 441681.7 & 195.2 & 185.2 & 252.2 & 4 & 196.4 & 195.5 & 0.8 & 0.34 & 195.9 & 0.17 \\
\hline CMP $32 D$ & 3676707.8 & 441684.6 & 228.6 & 218.6 & 252.6 & 3 & 221.0 & 221.0 & 0.1 & 0.07 & 2210 & 0.04 \\
\hline CAP 1 & 3679011.0 & 436353.2 & 217.8 & 187.8 & 272.8 & 24 & 212.4 & 204.7 & 7.7 & 2.33 & 208.1 & 0.48 \\
\hline CAP 3 & 3678956.3 & 436253.2 & 214.0 & 184.0 & 264.0 & 9 & 210.4 & 205.4 & 5.0 & 1.37 & 208.1 & 0.46 \\
\hline$C A P$ SD & 3678965.5 & 436251.1 & 214.3 & 194.3 & 265.3 & 10 & 208.6 & 206.1 & 2.5 & 0.86 & 207.6 & 0.27 \\
\hline CAP 4 & 3678920.5 & 436317.0 & 210.7 & 180.7 & 265.7 & 27 & 213.1 & 204.2 & 8.9 & 2.76 & 208.2 & 0.53 \\
\hline CAP 5D & 3679019.8 & 436400.7 & 214.6 & 194.6 & 274.6 & 10 & 212.9 & 209.9 & 3.0 & 1.28 & 211.7 & 0.40 \\
\hline CRP 70 & 36791018 & 436177.8 & 208.0 & 188.0 & 263.0 & 11 & 211.3 & 205.1 & 6.2 & 1.75 & 206.5 & 0.53 \\
\hline CAP QD & 3678895.3 & 436177.2 & 211.0 & 191.0 & 246.0 & 5 & 207.7 & 205.5 & 2.3 & 0.91 & 206.9 & 0.41 \\
\hline CAP $9 D$ & 3679120.8 & 436224.8 & 211.4 & 191.4 & 268.4 & 6 & 207.6 & 205.8 & 1.8 & 0.81 & 206.8 & 0.33 \\
\hline $\operatorname{CSA} 1$ & 3678378.3 & 439009.3 & 262.0 & 232.0 & 289.0 & 23 & 248.3 & 239.2 & 9.0 & 3.64 & 243.5 & 0.76 \\
\hline $\mathrm{CSA} 2$ & 3678370.5 & 439022.9 & 248.2 & 218.2 & 288.2 & 24 & 252.7 & 239.2 & 13.5 & 4.1 & 243.9 & 0.84 \\
\hline $\operatorname{CSA} 3$ & 3678352.3 & 439019.2 & 248.6 & 218.6 & 287.6 & 24 & 248.3 & 238.6 & 9.7 & 3.64 & 243.2 & 0.74 \\
\hline $\mathrm{CSA} 4$ & 3678360.3 & 438998.2 & 248.4 & 218.4 & 288.4 & 24 & 247.9 & 238.5 & 9.4 & 3.7 & 242.9 & 0.76 \\
\hline CSB $1 A$ & 3678866.5 & 436685.2 & 224.9 & 194.9 & 289.9 & 22 & 216.9 & 208.7 & 8.2 & 2.11 & 213.7 & 0.45 \\
\hline $\mathrm{CSB} 2 \mathrm{~A}$ & 3678766.3 & 436693.7 & 222.6 & 192.6 & 282.6 & 21 & 216.2 & 206.5 & 9.7 & 3.24 & 210.7 & 0.71 \\
\hline CSB $3 A$ & 3678757.0 & 436642.2 & 223.0 & 193.0 & 283.0 & 29 & 215.7 & 206.1 & 9.6 & 3.08 & 210.8 & 0.57 \\
\hline CSB $4 A$ & 3678795.3 & 436603.2 & 218.0 & 188.0 & 283.0 & 31 & 215.6 & 206.0 & 9.6 & 3.12 & 210.9 & 0.56 \\
\hline CSB $5 A$ & 3678842.0 & 436569.3 & 215.9 & 185.9 & 280.9 & 31 & 215.5 & 206.1 & 9.4 & 3.01 & 210.9 & 0.54 \\
\hline CSB $6 A$ & 3678901.0 & 436618.7 & 219.8 & 189.8 & 284.8 & 27 & 216.4 & 206.9 & 9.5 & 3.07 & 211.5 & 0.59 \\
\hline CSD iD & 3678730.0 & 438743.2 & 273.4 & 238.4 & 313.4 & 23 & 248.3 & 241.1 & 7.2 & 2.68 & 244.9 & 0.56 \\
\hline CSD 20 & 3678693.3 & 438759.9 & 258.8 & 233.8 & 308.8 & 12 & 250.1 & 246.2 & 3.9 & 1.04 & 248.9 & 0.30 \\
\hline CSD $4 D$ & 36786825 & 438735.8 & 263.5 & 213.5 & 306.5 & 21 & 247.5 & 240.0 & 7.6 & 2.94 & 244.0 & 0.64 \\
\hline CSD \&D & 3678667.0 & 438688.2 & 256.8 & 226.8 & 301.8 & 22 & 247.0 & 239.7 & 7.3 & 2.68 & 243.1 & 0.57 \\
\hline CSD $9 D$ & 3678627.5 & 438692.8 & 256.2 & 226.2 & 296.2 & 21 & 246.7 & 239.4 & 7.3 & 2.82 & 243.2 & 0.62 \\
\hline CSD 1OD & 3678625.0 & 438682.5 & 254.5 & 224.5 & 294.5 & 21 & 246.6 & 239.3 & 7.3 & 2.82 & 243.1 & 0.62 \\
\hline CSO 11D & 3678829.8 & 438517.4 & 250.9 & 220.9 & 290.9 & 21 & 246.6 & 238.9 & 7.6 & 3 & 243.0 & 0.65 \\
\hline CSD 12D & 3678626.3 & 438730.8 & 254.5 & 224.5 & 299.5 & 21 & 247.2 & 239.7 & 7.5 & 2.87 & 243.6 & 0.63 \\
\hline $\operatorname{CsD} 130$ & 3678551.3 & 438683.0 & 252.4 & 202.4 & 287.4 & 22 & 246.0 & 238.1 & 7.9 & 2.96 & 242.4 & 0.63 \\
\hline CSF 10 & 3678379.0 & 438720.2 & 248.2 & 2282 & 293.2 & 3 & 243.7 & 243.2 & 0.5 & 0.3 & 243.4 & 0.17 \\
\hline CSF 20 & 3678314.8 & 439313.1 & 255.2 & 235.2 & 289.2 & 2 & 251.3 & 250.6 & 0.7 & 0.48 & 251.0 & 0.34 \\
\hline Cso 1 & 3678606.8 & 439704.9 & 262.0 & 232.0 & 302.0 & 24 & 257.6 & 244.6 & 13.0 & 3.99 & 251.3 & 0.81 \\
\hline CSA 1 & 3679487.5 & 439184.5 & 267.2 & 237.2 & 272.2 & 21 & 261.4 & 245.9 & 15.4 & 3.96 & 255.9 & 0.86 \\
\hline
\end{tabular}




\begin{tabular}{|c|c|c|c|c|c|c|c|c|c|c|c|c|}
\hline Well ID & UTMN & UTME & Sz top & Szbot. & Gr. Elev. & No. & Max. & Min. & Range & Std. Dev. & Mean WL & StdEr_Mean \\
\hline CSR 2 & 3679695.5 & 439304.6 & 285.5 & 255.5 & 295.5 & 18 & 278.8 & 255.9 & 23.0 & 6.66 & 265.2 & 1.57 \\
\hline $\operatorname{css} 3$ & 3679766.3 & 439142.0 & 268.1 & 238.1 & 283.1 & 21 & 259.0 & 247.0 & 12.0 & 4.06 & 254.6 & 0.89 \\
\hline $\operatorname{csR} 4$ & 3679561.0 & 439285.6 & 267.6 & 237.6 & 282.6 & 20 & 260.6 & 246.5 & 14.1 & 3.48 & 256.7 & 0.78 \\
\hline DBP 1 & 3673925.8 & 430364.8 & 123.2 & 93.2 & 133.2 & 27 & 124.5 & 116.2 & 8.3 & 2.05 & 119.9 & 0.39 \\
\hline $\mathrm{DBP} 2$ & 3673827.8 & 430340.3 & 114.3 & 84.3 & 124.3 & 28 & 120.4 & 114.5 & 6.0 & 1.46 & 117.4 & 0.28 \\
\hline DB̈ 3 & 3673904.5 & 430292.0 & 116.4 & 86.4 & 126.4 & 30 & 123.7 & 115.4 & 8.3 & 2.18 & 121.1 & 0.40 \\
\hline DBP 4 & 3673865.5 & 430288.2 & 114.2 & 84.2 & 124.2 & 27 & 121.7 & 114.6 & 7.1 & 1.8 & 119.1 & 0.35 \\
\hline DBP 5 & 3673866.0 & 430387.8 & 116.1 & 96.1 & 132.6 & 12 & 120.9 & 114.6 & 6.3 & 1.76 & 117.3 & 0.51 \\
\hline DCB $1 A$ & 3673484.0 & 431136.6 & 120.1 & 90.1 & 125.1 & 20 & 116.8 & 113.9 & 2.9 & 0.73 & 115.3 & 0.16 \\
\hline DCB $2 A$ & 3673524.5 & 431498.8 & 127.4 & 97.4 & 132.4 & 24 & 127.1 & 122.3 & 4.8 & 1.24 & 125.0 & 0.25 \\
\hline DCB $3 A$ & 3673337.8 & 431636.5 & 126.2 & 96.2 & 131.2 & 23 & 122.7 & 119.2 & 3.5 & 0.98 & 120.9 & 0.20 \\
\hline DCB $4 A$ & 3673265.8 & 431535.7 & 122.5 & 92.5 & 127.5 & 26 & 120.7 & 117.7 & 3.0 & 0.73 & 19.4 & 0.14 \\
\hline DCB $5 A$ & 3673312.5 & 431368.3 & 115.9 & 85.9 & 120.9 & 25 & 120.4 & 117.1 & 3.2 & 0.76 & 119.0 & 0.15 \\
\hline DCB 6 & 3673540.5 & 431141.9 & 129.5 & 109.5 & 131.5 & 25 & 119.9 & 115.5 & 4.4 & 0.91 & 116.9 & 0.18 \\
\hline $\mathrm{DCB} 7$ & 3673509.8 & 431185.8 & 128.9 & 108.9 & 130.9 & 25 & 119.4 & 116.4 & 3.1 & 0.79 & 118.1 & 0.16 \\
\hline DCB 8 & 36735555.0 & 431521.3 & 130.3 & 110.3 & 134.8 & 25 & 129.3 & 123.9 & 5.4 & 1.39 & 126.7 & 0.28 \\
\hline DCB 9 & 3673515.3 & 431095.5 & 117.3 & 97.3 & 120.2 & 23 & 116.9 & 113.6 & 3.3 & 0.78 & 114.9 & 0.16 \\
\hline DCB 10 & 3673427.8 & 431176.1 & 119.8 & 99.8 & 121.8 & 24 & 120.2 & 113.5 & 6.8 & 1.92 & 116.9 & 0.39 \\
\hline DCB 11 & 3673525.3 & 430877.6 & 126.8 & 106.8 & 128.8 & 24 & 127.4 & 120.1 & 7.3 & 1.72 & 122.1 & 0.35 \\
\hline DCB 12 & 3673522.5 & 430608.7 & 112.0 & 92.0 & 115.0 & 24 & 111.3 & 108.6 & 2.7 & 0.76 & 109.9 & 0.16 \\
\hline$D C B 13$ & 3673326.8 & 431017.0 & 122.1 & 102.0 & 127.8 & 23 & 124.2 & 110.4 & 13.9 & 4.41 & 116.4 & 0.92 \\
\hline DCB 14 & 3673618.0 & 430864.3 & 114.6 & 94.6 & 127.5 & 6 & 110.6 & 109.3 & 1.3 & 0.56 & 109.9 & 0.23 \\
\hline$O C B 15$ & 3673228.5 & 430485.8 & 119.9 & 99.8 & 125.4 & 22 & 115.7 & 108.0 & 7.7 & 2.19 & 1111.7 & 0.47 \\
\hline DCB 16 & 3673063.5 & 430596.6 & 120.1 & 100.1 & 125.9 & 25 & 116.1 & 110.1 & 6.0 & 1.31 & 112.0 & 0.26 \\
\hline DCB 17A & 3673618.0 & 431033.6 & 119.4 & 109.4 & 127.4 & 2 & 116.5 & 116.4 & 0.0 & 0.04 & 116.4 & 0.03 \\
\hline DCB $18 A$ & 36734494.3 & 431138.6 & 120.1 & 110.1 & 125.1 & 3 & 116.4 & 115.4 & 1.0 & 0.55 & 115.8 & 0.32 \\
\hline DCB $19 A$ & 3673488.5 & 431146.2 & 121.9 & 111.9 & 126.4 & 2 & 119.1 & 119.0 & 0.1 & 0.06 & 119.1 & 0.04 \\
\hline$D C B 20 A$ & 367350550 & 431215.8 & 120.9 & 110.9 & 130.9 & 2 & 117.0 & 117.0 & 0.0 & 0 & 117.0 & 0.00 \\
\hline$D C B 21 A$ & 3673455.8 & 431156.6 & 120.1 & 110.1 & 126.6 & 2 & 117.0 & 116.2 & 0.8 & 0.55 & 116.6 & 0.39 \\
\hline DCB $22 A$ & 3673443.0 & 431143.0 & 119.8 & 109.8 & 125.3 & 3 & 112.7 & 112.6 & 0.0 & 0 & 112.6 & 0.00 \\
\hline DCB $23 A$ & 3673400.5 & 431103.9 & 115.7 & 105.7 & 119.2 & 3 & 111.8 & 1111.7 & 0.1 & 0.08 & 111.8 & 0.05 \\
\hline DCB 24A & 3673332.8 & 431294.6 & 119.2 & 109.2 & 122.2 & 2 & 115.4 & 115.3 & 0.0 & 0.02 & 115.3 & 0.01 \\
\hline $\mathrm{DOB} 1$ & 3675236.0 & 431260.2 & 144.7 & 114.7 & 149.7 & 40 & 146.9 & 137.4 & 9.5 & 2.41 & 143.7 & 0.38 \\
\hline DOB 2 & 3675227.3 & 431181.0 & 145.3 & 115.3 & 150.3 & 40 & 148.4 & 137.1 & 11.3 & 2.5 & 143.7 & 0.40 \\
\hline DOB 3 & 3675310.8 & 431230.5 & 145.9 & 115.9 & 150.9 & 29 & 147.4 & 137.4 & 10.1 & 2.84 & 143.7 & 0.53 \\
\hline $\mathrm{DOB} 4$ & 3675299.3 & 431307.5 & 139.2 & 109.2 & 151.2 & 29 & 146.8 & 136.9 & 9.9 & 276 & 143.0 & 0.51 \\
\hline DOB 7 & 36751910 & 4312619 & 145.7 & 125.7 & 148.7 & 13 & 144.7 & 139.0 & 5.7 & 1.86 & 143.2 & 0.52 \\
\hline DOB 8 & 3675259.3 & 431296.9 & 148.3 & 128.3 & 151.3 & 13 & 145.3 & 139.5 & 5.8 & 1.76 & 143.8 & 0.49 \\
\hline $\mathrm{DOB} 9$ & 3675350.0 & 431223.5 & 148.5 & 128.5 & 151.5 & 3 & 144.9 & 143.5 & 1.4 & 0.72 & 144.1 & 0.42 \\
\hline DOB 10 & 3675199.5 & 431182.6 & 148.3 & 128.3 & 151.3 & 13 & 144.8 & 139.3 & 5.5 & 1.65 & 143.4 & 0.46 \\
\hline DOB 12 & 3675208.5 & 431216.5 & 137.9 & 132.9 & 149.6 & 15 & 141.9 & 136.5 & 5.4 & 1.49 & 140.4 & 0.38 \\
\hline DOB 14 & 3675203.3 & 431268.8 & 137.4 & 132.4 & 149.1 & 3 & 140.2 & 139.1 & 1.1 & 0.58 & 139.5 & 0.33 \\
\hline$F 10$ & 3681710.5 & 436676.7 & 276.5 & 266.5 & 277.5 & 1 & 269.1 & 269.1 & 0.0 & - & 269.1 & \\
\hline$F \quad 18 A$ & 3681407.5 & 436770.5 & 204.4 & 194.4 & 231.4 & 5 & 213.6 & 201.9 & 11.7 & 5.09 & 204.5 & 2.28 \\
\hline FAB 1 & 3683163.8 & 437304.1 & 235.4 & 215.4 & 325.4 & 12 & 229.1 & 226.9 & 2.3 & 0.78 & 228.3 & 0.23 \\
\hline$F A B 2$ & 3683122.5 & 437417.8 & 236.5 & 216.5 & 326.5 & 13 & 229.9 & 227.6 & 2.3 & 0.75 & 229.1 & 0.21 \\
\hline FAB 3 & 3683024.8 & 437448.6 & 231.8 & 211.8 & 3218 & 11 & 2296 & 227.3 & 2.3 & 0.7 & 228.8 & 0.21 \\
\hline$F A B 4$ & 3683083.0 & 437304.1 & 234.2 & 214.2 & 324.2 & 10 & 229.3 & 227.0 & 2.4 & 0.7 & 228.5 & 0.22 \\
\hline FAC 3 & 3683290.8 & 437365.1 & 254.8 & 224.8 & 309.8 & 27 & 232.0 & 225.0 & 7.0 & 1.64 & 229.1 & 0.32 \\
\hline FAC 4 & 3683368.3 & 437365.2 & 237.8 & 207.8 & 307.8 & 27 & 231.3 & 226.4 & 4.9 & 0.54 & 228.6 & 0.30 \\
\hline FAC 5 & 3683261.8 & 437355.4 & 234.0 & 214.0 & 314.0 & 26 & 230.0 & 220.9 & 9.1 & 3.16 & 225.2 & 0.62 \\
\hline FAC $5 P$ & 368328.0 & 437334.9 & 235.7 & 225.7 & 310.9 & 4 & 230.7 & 229.1 & 1.6 & 0.76 & 230.0 & 0.38 \\
\hline FAC 6 & 3683320.3 & 437348.3 & 236.2 & 216.2 & 310.8 & 24 & 232.1 & 216.2 & 15.9 & 4.19 & 220.9 & 0.86 \\
\hline FAC 7 & 3683322.8 & 437354.5 & 235.7 & 215.7 & 310.3 & 27 & 230.2 & 216.1 & 74.1 & 5.53 & 223.6 & 1.06 \\
\hline FAC 8 & 3683316.5 & 437362.7 & 2360 & 216.0 & 309.0 & 27 & 232.0 & 221.6 & 10.5 & 3.94 & 227.4 & 0.76 \\
\hline FAL 1 & 3683034.0 & 436961.7 & 238.5 & 207.0 & 310.5 & 31 & 221.7 & 216.5 & 5.2 & 1.84 & 218.8 & 0.33 \\
\hline FAL 2 & 3683002.8 & 436941.1 & 238.0 & 206.6 & 310.0 & 29 & 220.1 & 214.8 & 5.2 & 1.83 & 217.2 & 0.34 \\
\hline$F B P 5 D$ & 3682818.5 & 436107.6 & 212.6 & 1926 & 290.1 & 13 & 2080 & 2030 & 5.0 & 1.54 & 2053 & 0.43 \\
\hline FBP $6 D$ & 3682842.0 & 435891.8 & 198.3 & 178.3 & 287.3 & 15 & 199.0 & 192.0 & 7.0 & 2.2 & 194.9 & 0.57 \\
\hline FBP 70 & 3682934.3 & 435949.8 & 203.2 & 183.2 & 2922 & 4 & 194.7 & 194.2 & 0.5 & 0.25 & 194.5 & 0.13 \\
\hline$F B P 9 D$ & 3682909.8 & 4360410 & 197.9 & 1779 & 281.9 & 11 & 2041 & 194.6 & 9.6 & 2.66 & 200.6 & 0.80 \\
\hline FBP $10 D$ & 3682755.3 & 435950.6 & 200.8 & 180.8 & 283.8 & 5 & 201.5 & 199.9 & 1.6 & 0.62 & 200.9 & 0.28 \\
\hline FBP 11D & 3682740.3 & 436049.1 & 212.1 & 192.0 & 287.3 & 5 & 203.4 & 202.9 & 0.5 & 0.21 & 203.3 & 0.09 \\
\hline FBP 13D & 3682887.0 & 435914.4 & 192.7 & 972.7 & 295.7 & 14 & 199.7 & 184.5 & 15.2 & 3.61 & 195.1 & 0.96 \\
\hline FCA 20 & 3683070.8 & 436919.3 & 239.0 & 219.0 & 310.3 & 34 & 228.5 & 219.1 & 9.4 & 2.5 & 224.9 & 0.43 \\
\hline FCA $9 D$ & 3683149.0 & 436869.0 & 241.9 & 221.9 & 309.9 & 23 & 227.2 & 2227 & 4.5 & 1.43 & 225.1 & 0.30 \\
\hline FCA $9 D R$ & 3683151.5 & 436867.9 & 227.7 & 207.7 & 310.2 & 14 & 225.6 & 220.2 & 5.4 & 1.52 & 224.0 & 0.41 \\
\hline FCA $10 A$ & 3683130.0 & 436822.2 & 241.0 & 221.0 & 310.0 & 34 & 228.1 & 222.9 & 5.2 & 1.55 & 225.3 & 0.27 \\
\hline
\end{tabular}




\begin{tabular}{|c|c|c|c|c|c|c|c|c|c|c|c|c|}
\hline Well ID & UTMN & UTME & Sz top & Sz bot. & Gr. Elev. & No. & Max. & Min. & Range & Sid. Dev. & Mean WL & StdEr_Mean \\
\hline FCA 10D & 3683158.8 & 436861.7 & 239.5 & 219.5 & 309.5 & 15 & 228.5 & 223.3 & 5.2 & 1.37 & 226.7 & 0.35 \\
\hline$F C A \quad 16 A$ & 3683193.3 & 436774.9 & 235.1 & 215.1 & 310.4 & 34 & 227.9 & 223.0 & 4.9 & 1.4 & 225.2 & 0.24 \\
\hline$F C A$ TGD & 3683220.0 & 4368123 & 241.1 & 221.1 & 310.1 & 20 & 227.7 & 2222 & 5.5 & 1.58 & 225.0 & 0.35 \\
\hline$F C A$ 19D & 3683065.8 & 436924.5 & 229.7 & 209.7 & 309.7 & 29 & 220.1 & 214.6 & 5.4 & 1.85 & 217.2 & 0.34 \\
\hline $\mathrm{FCB} 2$ & 3682911.5 & 437537.1 & 235.2 & 205.2 & 305.2 & 27 & 2324 & 2124 & 20.0 & 3.61 & 229.1 & 0.69 \\
\hline$F C B$ & 3682818.5 & 437539.8 & 225.3 & 195.3 & 300.3 & 26 & 227.5 & 221.0 & 6.6 & 1.79 & 224.1 & 0.35 \\
\hline FCB 4 & 3682857.3 & 437410.5 & 234.5 & 204.5 & 304.5 & 28 & 231.3 & 211.0 & 20.4 & 3.65 & 228.1 & 0.69 \\
\hline $\mathrm{FCB} 5$ & 3682816.3 & 437503.2 & 237.1 & 217.1 & 301.7 & 28 & 232.0 & 225.1 & 6.9 & 1.75 & 228.9 & 0.33 \\
\hline FCB 6 & 3682831.3 & 437477.4 & 235.1 & 215.1 & 308.4 & 25 & 231.7 & 227.0 & 4.7 & 1.42 & 229.1 & 0.28 \\
\hline $\mathrm{FCB} 7$ & 3682953.0 & 437473.0 & 238.3 & 218.3 & 313.1 & 1 & 231.0 & 231.0 & 0.0 & - & 231.0 & \\
\hline FET $1 D$ & 3682471.5 & 437199.0 & 226.9 & 206.9 & 268.0 & 26 & 226.4 & 221.8 & 4.5 & 1.45 & 223.6 & 0.28 \\
\hline FET $2 D$ & 3682385.0 & 437141.9 & 229.5 & 209.5 & 267.9 & 26 & 225.2 & 220.5 & 4.7 & 1.54 & 222.3 & 0.30 \\
\hline FET 30 & 3682372.0 & 437168.1 & 223.0 & 203.0 & 283.2 & 26 & 225.1 & 220.5 & 4.6 & 1.51 & 2224 & 0.30 \\
\hline FET AD & 3682393.8 & 437198.8 & 225.1 & 205.1 & 284.7 & 27 & 225.5 & 220.9 & 4.7 & 1.51 & 222.7 & 0.29 \\
\hline$F I W 2 M D$ & 3682038.5 & 4367236 & 220.8 & 190.9 & 290.3 & 1 & 215.5 & 215.5 & 0.0 & $=$ & 215.5 & \\
\hline$F N B$ & 3683627.8 & 436723.6 & 207.2 & 177.2 & 2822 & 26 & 215.0 & 207.8 & 7.1 & 2.31 & 211.1 & 0.45 \\
\hline $\mathrm{FNB} 2$ & 3683715.5 & 436693.7 & 210.8 & 180.8 & 285.8 & 27 & 211.9 & 204.0 & 7.9 & 2.42 & 207.3 & 0.47 \\
\hline FNB 3 & 3683697.0 & 436610.7 & 212.1 & 182.1 & 2821 & 27 & 213.5 & 205.6 & 7.8 & 2.45 & 209.5 & 0.47 \\
\hline FNB 4 & 3683614.5 & 436571.8 & 209.6 & 179.6 & 289.6 & 27 & 218.3 & 209.8 & 8.6 & 2.83 & 213.8 & 0.54 \\
\hline FNB 5 & 3683731.8 & 436656.8 & 203.5 & 193.5 & 285.5 & 8 & 208.0 & 205.0 & 3.0 & 1.12 & 206.7 & 0.40 \\
\hline FSB OPD & 3681454.8 & 436638.9 & 215.3 & 171.6 & 252.6 & 5 & 207.7 & 206.0 & 1.7 & 0.77 & 207.4 & 0.34 \\
\hline FSB 50 PD & 3681471.8 & 436635.8 & 219.8 & 174.7 & 255.7 & 1 & 206.2 & 206.2 & 0.0 & $\div$ & 206.2 & \\
\hline FSB 76 & 3682123.0 & 436732.5 & 227.0 & 197.0 & 2920 & 43 & 229.9 & 214.2 & 15.7 & 2.41 & 218.1 & 0.37 \\
\hline FSB 77 & 3681752.5 & 436747.5 & 216.4 & 186.4 & 271.4 & 52 & 215.8 & 207.8 & 8.1 & 1.55 & 212.0 & 0.21 \\
\hline FSB 78 & 3681564.0 & 436678.0 & 217.7 & 187.7 & 270.7 & 58 & 212.2 & 194.1 & 18.1 & 2.32 & 208.6 & 0.30 \\
\hline FSB 79 & 3681288.3 & 436869.2 & 204.1 & 174.1 & 216.1 & 54 & 203.8 & 191.3 & 12.5 & 2.17 & 201.9 & 0.30 \\
\hline FSB 870 & 3681751.8 & 436509.9 & 216.8 & 187.4 & 285.3 & 14 & 215.5 & 213.0 & 2.5 & 0.85 & 213.9 & 0.23 \\
\hline FSB 880 & 3682019.8 & 436859.8 & 222.1 & 202.1 & 280.1 & 48 & 219.6 & 212.9 & 6.7 & 1.57 & 216.0 & 0.23 \\
\hline FSB 890 & 3681967.3 & 436825.8 & 221.9 & 201.9 & 278.9 & 46 & 218.9 & 212.3 & 6.6 & 1.6 & 215.3 & 0.24 \\
\hline FSB GOD & 3681890.0 & 436808.5 & 225.1 & 205.1 & 276.1 & 28 & 234.8 & 210.5 & 24.3 & 4.41 & 215.0 & 0.83 \\
\hline FSB 910 & 3681813.5 & 436791.0 & 220.9 & 200.9 & 276.9 & 45 & 216.2 & 210.8 & 5.4 & 1.54 & 213.5 & 0.23 \\
\hline FSB 920 & 3681704.0 & 436724.2 & 221.7 & 201.7 & 273.7 & 46 & 215.3 & 209.1 & 6.2 & 1.39 & 211.7 & 0.20 \\
\hline FSB 930 & 3681646.3 & 436726.5 & 217.9 & 197.9 & 273.9 & 51 & 216.7 & 2079 & 8.7 & 1.61 & 210.5 & 0.23 \\
\hline FSB $950 R$ & 3681590.0 & 436595.6 & 207.0 & 187.0 & 282.0 & 38 & 213.2 & 208.4 & 4.8 & 1.27 & 210.2 & 0.21 \\
\hline FSB 97D & 3681634.8 & 436555.2 & 216.9 & 196.9 & 283.9 & 52 & 213.9 & 208.0 & 5.9 & 1.45 & 210.6 & 0.20 \\
\hline FSB 98D & 3681704.3 & 436555.9 & 220.3 & 200.3 & 282.3 & 47 & 215.4 & 210.0 & 5.4 & 1.47 & 212.1 & 0.21 \\
\hline FSB 99D & 3681821.8 & 436551.6 & 218.1 & 198.1 & 285.1 & 54 & 215.3 & 208.5 & 6.8 & 1.77 & 211.8 & 0.24 \\
\hline FSB104D & 3681179.5 & 436615.1 & 210.4 & 190.4 & 216.9 & 46 & 206.5 & 200.6 & 5.9 & 1.3 & 204.3 & 0.19 \\
\hline FSB $105 D$ & 3681623.0 & 436510.2 & 223.7 & 203.7 & 283.7 & 8 & 208.6 & 207.2 & 1.3 & 0.47 & 207.7 & 0.17 \\
\hline FSB 105DA & 3681627.8 & 436509.6 & 208.6 & 188.5 & 283.6 & 38 & 213.6 & 208.7 & 4.9 & 1.22 & 210.7 & 0.20 \\
\hline FSB106D & 3681508.0 & 436896.7 & 222.9 & 202.9 & 232.9 & 24 & 214.9 & 205.9 & 9.0 & 1.8 & 207.1 & 0.37 \\
\hline FSB107D & 3681842.5 & 436846.5 & 220.9 & 200.9 & 268.7 & 52 & 217.5 & 210.9 & 6.6 & 1.5 & 213.6 & 0.21 \\
\hline FSB $10 B D$ & 3682108.0 & 436650.4 & 223.8 & 203.8 & 295.8 & 67 & 221.1 & 209.2 & 11.9 & 2.1 & 217.7 & 0.26 \\
\hline FSB $109 D$ & 3681891.0 & 436561.9 & 225.8 & 205.8 & 290.8 & 50 & 217.0 & 207.7 & 9.3 & 2.04 & 213.2 & 0.29 \\
\hline FSBITOD & 3681419.3 & 436774.6 & 211.1 & 191.1 & 232.6 & 52 & 208.8 & 203.2 & 5.5 & 1.13 & 205.4 & 0.16 \\
\hline FSBIIID & 3681958.8 & 436899.8 & 221.7 & 201.7 & 274.4 & 47 & 219.0 & 211.6 & 7.3 & 1.73 & 215.1 & 0.25 \\
\hline FSB112D & 3681182.5 & 436433.7 & 208.9 & 188.9 & 227.6 & 38 & 208.4 & 204.0 & 4.4 & 1.03 & 205.9 & 0.17 \\
\hline FSBITOD & 3681581.5 & 437017.2 & 209.6 & 189.6 & 220.6 & 38 & 209.4 & 204.5 & 49 & 0.98 & 207.3 & 0.16 \\
\hline FSB $114 D$ & 3682023.3 & 437042.4 & 217.8 & 197.7 & 250.2 & 38 & 220.0 & 215.1 & 5.0 & 1.13 & 217.0 & 0.18 \\
\hline FSBIISD & 3680929.0 & 436975.7 & 192.5 & 182.5 & 206.5 & 39 & 193.1 & 188.9 & 4.2 & 1.06 & 191.3 & 0.17 \\
\hline FSB 1160 & 3681145.8 & 437157.8 & 196.4 & 186.4 & 200.9 & 42 & 193.3 & 189.6 & 3.7 & 0.72 & 191.9 & 0.11 \\
\hline FSBITOO & 3681451.0 & 436881.7 & 209.7 & 189.7 & 228.7 & 36 & 207.1 & 203.9 & 3.2 & 0.77 & 205.0 & 0.13 \\
\hline FSB 1180 & 3681747.0 & 436963.7 & 211.3 & 191.3 & 241.3 & 38 & 214.6 & 207.6 & 6.9 & 1.37 & 211.4 & 0.22 \\
\hline FSBITOD & 3681601.8 & 436814.8 & 213.1 & 193.1 & 252.1 & 44 & 211.3 & 2060 & 5.4 & 1.05 & 208.1 & 0.16 \\
\hline FSB12OD & 3681582.8 & 436287.1 & 296.5 & 196.5 & 278.5 & 43 & 212.6 & 202.3 & 10.3 & 1.79 & 209.4 & 0.27 \\
\hline FSBM121DR & 3681348.5 & 4361810 & 211.3 & 191.3 & 253.3 & 34 & 209.8 & 205.0 & 4.8 & 1.22 & 207.0 & 0.21 \\
\hline FSB122D & 3680990.8 & 436355.5 & 206.6 & 186.6 & 215.6 & 39 & 206.7 & 201.4 & 5.3 & 1.24 & 203.4 & 0.20 \\
\hline FSB 123D & 3681796.0 & 437100.9 & 214.1 & 194.1 & 236.1 & 39 & 214.5 & 210.1 & 4.4 & 0.99 & 212.1 & 0.16 \\
\hline FSB 150 PD & 3681447.5 & 436594.5 & 221.3 & 176.2 & 257.2 & 1 & 206.2 & 206.2 & 0.0 & - & 206.2 & \\
\hline FSL ID & 36831303 & 436603.6 & 228.6 & 208.5 & 308.6 & 33 & 227.1 & 222.9 & 4.2 & 1.08 & 224.7 & 0.19 \\
\hline FSL $2 D$ & 3682989.0 & 436630.4 & 228.8 & 208.7 & 303.8 & 34 & 227.6 & 221 & 5.5 & 1.28 & 225.2 & 0.22 \\
\hline FSL $3 D$ & 3682716.0 & 436706.5 & 226.0 & 205.9 & 300.0 & 31 & 231.7 & 220.8 & 10.9 & 2.01 & 223.1 & 0.36 \\
\hline FSL $4 D$ & 3682596.8 & 436704.8 & 224.1 & 204.0 & 292.1 & 31 & 219.9 & 215.4 & 4.5 & 1.11 & 217.5 & 0.20 \\
\hline FSL $5 D$ & 3682438.5 & 436696.7 & 223.7 & 203.5 & 289.7 & 29 & 223.4 & 218.7 & 4.7 & 1.22 & 220.8 & 0.23 \\
\hline FSL $6 D$ & 3682329.5 & 436709.9 & 222.1 & 202.1 & 284.1 & 31 & 2226 & 217.9 & 4.7 & 1.18 & 220.1 & 0.21 \\
\hline FSL $7 D$ & 3682186.3 & 436722.9 & 219.6 & 199.5 & 285.6 & 30 & 226.7 & 216.0 & 10.8 & 2.03 & 218.3 & 0.37 \\
\hline FSL $8 D$ & 3682124.0 & 436778.8 & 222.8 & 202.7 & 288.8 & 29 & 220.4 & 215.2 & 5.2 & 1.22 & 217.4 & 0.23 \\
\hline FSL $9 D$ & 3682058.8 & 436837.6 & 221.5 & 201.4 & 283.5 & 28 & 220.0 & 214.8 & 5.2 & 1.24 & 216.9 & 0.23 \\
\hline
\end{tabular}




\begin{tabular}{|c|c|c|c|c|c|c|c|c|c|c|c|c|}
\hline Well ID & UTMN & UTME & Sz top & Sz bot. & Gr. Elev. & No. & Max. & Min. & Range & Std. Dev. & Mean WL & StdErr_Mean \\
\hline FSS 1D & 3682355.0 & 437509.1 & 229.9 & 209.9 & 263.9 & 38 & 227.4 & 221.4 & 6.0 & 1.49 & 223.7 & 0.24 \\
\hline FSS $2 D$ & 3682321.0 & 437541.9 & 224.4 & 204.4 & 259.4 & 38 & 227.0 & 220.7 & 6.3 & 1.51 & 223.0 & 0.24 \\
\hline FSS 30 & 3682219.3 & 437476.2 & 225.8 & 205.8 & 255.8 & 38 & 224.6 & 217.5 & 7.1 & 1.62 & 220.7 & 0.26 \\
\hline FSS 4D & 3682241.0 & 437207.2 & 2226 & 2026 & 289.8 & 38 & 222.5 & 215.5 & 7.0 & 19 & 218.9 & 0.31 \\
\hline FST ID & 3682969.5 & 435254.3 & 129.5 & 119.5 & 132.0 & 5 & 126.3 & 124.9 & 1.3 & 0.52 & 125.5 & 0.23 \\
\hline FIF 1 & 3682757.5 & 436945.6 & 241.2 & 221.2 & 281.2 & 5 & 233.1 & 225.0 & 8.1 & 3.51 & 226.9 & 1.57 \\
\hline FIF 2 & 3682755.5 & 436983.0 & 239.4 & 219.4 & 279.4 & 12 & 227.8 & 222.5 & 5.3 & 1.68 & $225.0^{\circ}$ & 0.48 \\
\hline FIF 3 & 3682725.3 & 436993.6 & 221.2 & 218.2 & 278.2 & 20 & 228.0 & 220.5 & 7.5 & 2.35 & 223.7 & 0.53 \\
\hline FIF 4 & 3682704.3 & 437017.7 & 236.6 & 216.6 & 276.6 & 22 & 227.0 & 219.8 & 7.2 & 1.94 & 223.8 & 0.41 \\
\hline FTF 5 & 3682662.3 & 437010.5 & 235.3 & 215.3 & 275.3 & 18 & 228.8 & 218.1 & 10.7 & 3 & 224.2 & 0.71 \\
\hline FIF 6 & 3682671.8 & 436963.6 & 236.9 & 216.9 & 276.9 & 16 & 227.0 & 219.3 & 7.7 & 2.39 & 223.9 & 0.60 \\
\hline FTF 7 & 3682697.5 & 436955.3 & 226.1 & 222.1 & 278.1 & 21 & 227.0 & 220.7 & 6.3 & 1.96 & 223.7 & 0.43 \\
\hline FIF 8 & 3682717.0 & 436929.9 & 239.6 & 219.6 & 279.6 & 7 & 235.7 & 224.5 & 11.2 & 3.91 & 227.0 & 1.48 \\
\hline FIF 9 & 3682701.0 & 436832.1 & 236.4 & 216.4 & 270.4 & 12 & 225.9 & 221.1 & 4.8 & 1.44 & 224.0 & 0.42 \\
\hline FTF 10 & 3682689.0 & 436891.8 & 235.1 & 215.1 & 269.1 & 9 & 225.5 & 223.1 & 2.4 & 0.78 & 224.4 & 0.26 \\
\hline FTF 11 & 3682622.8 & 436881.2 & 235.8 & 215.8 & 269.8 & 9 & 229.0 & 223.0 & 6.1 & 1.78 & 224.6 & 0.59 \\
\hline FIF 12 & 3682639.5 & 436831.2 & 235.0 & 215.0 & 269.0 & 23 & 228.7 & 220.5 & 8.2 & 1.77 & 226.6 & 0.37 \\
\hline FIF 13 & 3682551.8 & 437064.7 & 236.1 & 216.1 & 284.1 & 15 & 234.8 & 2223 & 12.5 & 2.93 & 225.8 & 0.76 \\
\hline FIF 15 & 3682598.5 & 437080.2 & 227.5 & 197.5 & 284.5 & 24 & 236.5 & 2220 & 14.5 & 3.75 & 225.3 & 0.77 \\
\hline FTF 16 & 3682542.3 & 436989.1 & 233.8 & 203.8 & 286.8 & 24 & 235.1 & 219.8 & 15.3 & 3.13 & 223.2 & 0.64 \\
\hline FFF 17 & 3682571.0 & 436969.8 & 230.6 & 200.6 & 287.6 & 25 & 227.6 & 219.8 & 7.8 & 2.19 & 222.8 & 0.44 \\
\hline FIF 18 & 3682590.8 & 436953.6 & 232.3 & 202.3 & 286.3 & 23 & 235.0 & 219.3 & 15.7 & 3.31 & 223.1 & 0.69 \\
\hline FTF 19 & 3682598.5 & 436869.3 & 228.3 & 198.3 & 285.3 & 24 & 227.2 & 219.2 & 8.0 & 2.27 & 222.2 & 0.46 \\
\hline FF 20 & 3682537.3 & 436849.6 & 228.3 & 198.3 & 285.3 & 25 & 225.1 & 218.7 & 6.4 & 1.93 & 221.6 & 0.39 \\
\hline FIF 21 & 3682500.5 & 436875.8 & 2287 & 198.7 & 285.7 & 25 & 226.5 & 219.5 & 7.0 & 1.52 & 223.1 & 0.30 \\
\hline FIF 22 & 3682471.5 & 436895.6 & 242.6 & 212.6 & 284.6 & 25 & 226.8 & 218.3 & 8.5 & 2.22 & 221.7 & 0.44 \\
\hline FIF 23 & 3682466.8 & 436961.4 & 231.2 & 201.2 & 284.2 & 24 & 228.5 & 219.3 & 9.2 & 2.31 & 222.2 & 0.47 \\
\hline FIF 24A & 3682647.3 & 436875.4 & 232.7 & 212.7 & 268.4 & 23 & 225.8 & 219.8 & 6.0 & 2.05 & 222.6 & 0.43 \\
\hline TF $25 \mathrm{~A}$ & 3682675.8 & 436887.8 & 232.8 & 2128 & 269.1 & 24 & 226.2 & 220.1 & 6.1 & 1.96 & 223.1 & 0.40 \\
\hline FTF 26 & 3682662.5 & 436899.9 & 226.3 & 206.3 & 268.8 & 23 & 226.4 & 219.9 & 6.5 & 2.05 & 223.0 & 0.43 \\
\hline FIF 27 & 3682647.8 & 436891.3 & 243.5 & 213.5 & 268.5 & 24 & 229.7 & 219.9 & 9.8 & 2.36 & 223.0 & 0.48 \\
\hline GBW 1 & 3691415.5 & 443676.8 & 279.6 & 249.6 & 332.6 & 18 & 266.4 & 257.7 & 8.7 & 3.13 & 260.6 & 0.74 \\
\hline H 6 & 3682350.8 & 439184.9 & 235.2 & 225.2 & 259.2 & 1 & 230.2 & 230.2 & 0.0 & 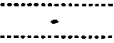 & 230.2 & \\
\hline 47 & 3682336.0 & 439195.8 & 234.9 & 224.9 & 256.9 & 1 & 227.7 & 227.7 & 0.0 & $\because$ & 227.7 & \\
\hline H 8 & 3682235.5 & 439230.5 & 228.4 & 218.4 & 253.8 & 3 & 227.2 & 226.0 & 1.2 & 0.7 & 226.8 & 0.40 \\
\hline H 10 & 3682159.8 & 439130.7 & 232.5 & 222.5 & 254.5 & 3 & 227.3 & 226.3 & 1.0 & 0.58 & 226.6 & \\
\hline $\mathrm{HI1}$ & 3682141.8 & 439127.4 & 222.0 & 212.0 & 246.0 & 1 & 226.3 & 226.3 & 0.0 & $\cdots$ & 226.3 & \\
\hline H $18 \mathrm{~A}$ & 3682006.8 & 439059.1 & 227.5 & 217.5 & 237.5 & 14 & 226.1 & 221.7 & 4.4 & 1.23 & 224.0 & 0.33 \\
\hline H 19 & 3681977.0 & 438969.3 & 221.1 & 219.6 & 243.7 & 3 & 224.8 & 223.6 & 1.2 & 0.61 & 224.2 & 0.35 \\
\hline HAA 10 & 3682655.8 & 440717.3 & 281.8 & 261.8 & 291.8 & 8 & 279.3 & 274.7 & 4.6 & 1.54 & 276.4 & 0.54 \\
\hline HAA 20 & 3682611.3 & 440093.8 & 280.4 & 260.3 & 290.8 & 9 & 278.6 & 275.7 & 2.9 & 0.89 & 276.6 & 0.30 \\
\hline HAA 3D & 3682531.3 & 439738.9 & 266.7 & 246.7 & 271.3 & 8 & 267.7 & 259.3 & 8.4 & 2.78 & 262.6 & 0.98 \\
\hline HAA 4D & 3683040.8 & 440022.1 & 275.7 & 255.7 & 298.7 & 8 & 271.4 & 268.5 & 2.9 & 1.05 & 269.9 & 0.37 \\
\hline HAA $6 D$ & 3683208.5 & 440657.8 & 267.2 & 247.1 & 278.8 & 9 & 267.1 & 263.7 & 3.4 & 0.99 & 264.9 & 0.33 \\
\hline $\mathrm{HAC} 1$ & 3682942.8 & 439914.5 & 278.8 & 258.8 & 296.4 & 27 & 272.4 & 266.1 & 6.3 & 1.57 & 269.5 & 0.30 \\
\hline $\mathrm{HAC} 2$ & 3682946.3 & 439893.8 & 278.8 & 258.8 & 296.2 & 27 & 272.7 & 265.5 & 7.2 & 1.73 & 269.1 & 0.33 \\
\hline HAC 3 & 3682927.8 & 439887.3 & 275.0 & 255.0 & 295.4 & 28 & 271.8 & 265.9 & 5.9 & 1.5 & 269.2 & 0.28 \\
\hline HAC 4 & 3682922.5 & 439913.0 & 274.1 & 254.1 & 294.7 & 27 & 272.8 & 266.3 & 6.5 & 1.59 & 269.7 & 0.31 \\
\hline HAP 1 & 3683061.8 & 440575.6 & 276.3 & 256.3 & 287.3 & 19 & 273.8 & 268.9 & 4.9 & 1.32 & 271.2 & 0.30 \\
\hline HCA 1 & 3683333.0 & 440268.9 & 273.7 & 253.7 & 307.7 & 30 & 272.6 & 266.1 & 6.5 & 1.36 & 269.7 & 0.25 \\
\hline HCA 2 & 3683240.3 & 440274.0 & 273.4 & 242.0 & 308.4 & 29 & 273.7 & 267.0 & 6.7 & 1.44 & 270.6 & 0.27 \\
\hline $\mathrm{HCA} 3$ & 3683365.0 & 440245.5 & 273.8 & 253.8 & 307.8 & 30 & 272.3 & 266.2 & 6.1 & 1.27 & 269.4 & 0.23 \\
\hline $\mathrm{BCA} 4$ & 3683303.8 & 440227.6 & 273.3 & 241.9 & 308.3 & 36 & 273.0 & 266.0 & 7.0 & 1.45 & 269.6 & 0.24 \\
\hline $\mathrm{HCB} 2$ & 3683153.0 & 440659.6 & 269.9 & 239.9 & 279.9 & 28 & 270.8 & 265.6 & 5.2 & 1.14 & 268.4 & 0.22 \\
\hline $\mathrm{HCB} 3$ & 3683127.8 & 440723.8 & 263.6 & 233.6 & 273.6 & 26 & 268.7 & 264.8 & 3.9 & 0.89 & 266.8 & 0.17 \\
\hline $\mathrm{HCB} 4$ & 3683187.8 & 440730.9 & 265.9 & 235.9 & 275.9 & 26 & 267.2 & 261.8 & 5.4 & 1.28 & 264.7 & 0.25 \\
\hline HET $2 D$ & 3682665.3 & 439618.8 & 259.7 & 239.7 & 274.8 & 30 & 262.8 & 255.6 & 7.3 & 1.89 & 258.7 & 0.35 \\
\hline HET 3D & 3682689.8 & 439606.9 & 259.9 & 239.9 & 274.6 & 32 & 263.1 & 255.8 & 7.3 & 1.81 & 259.0 & 0.32 \\
\hline $\mathrm{HET} 4 \mathrm{D}$ & 3682720.8 & 439605.7 & 259.6 & 239.5 & 274.5 & 30 & 262.7 & 256.6 & 6.2 & 1.67 & 259.4 & 0.30 \\
\hline $\mathrm{HIW} 1 \mathrm{MD}$ & 3682510.0 & 439125.6 & 239.7 & 214.9 & 272.7 & 1 & 232.1 & 232.1 & 0.0 & $-\cdots$ & 2321 & \\
\hline HIW IPD & 3682493.0 & 439103.8 & 240.5 & 215.5 & 274.5 & 1 & 231.7 & 231.7 & 0.0 & $=$ & 231.7 & \\
\hline HIW 20 & 3682376.8 & 438568.4 & 230.8 & 210.9 & 275.8 & 6 & 230.5 & 226.9 & 3.6 & 1.29 & 229.1 & 0.53 \\
\hline HMD 10 & 3683762.5 & 437643.8 & 219.7 & 199.7 & 262.7 & 31 & 212.8 & 206.9 & 5.9 & 9.54 & 209.7 & 0.28 \\
\hline HMD 20 & 3684045.8 & 437549.3 & 210.8 & 190.8 & 259.3 & 32 & 204.5 & 198.4 & 6.1 & 1.64 & 200.8 & 0.29 \\
\hline$H M D$ 3D & 3684109.5 & 437682.0 & 207.7 & 187.7 & 257.5 & 31 & 204.0 & 197.8 & 6.2 & 1.62 & 200.2 & 0.29 \\
\hline HMD 4D & 3684086.0 & 437866.2 & 208.9 & 188.9 & 248.5 & 31 & 204.0 & 192.7 & 11.3 & 2.87 & 199.6 & 0.52 \\
\hline HR8 12 & 3682472.5 & 439471.0 & 235.9 & 206.3 & 255.7 & 27 & 244.6 & 238.1 & 6.5 & 1.28 & 239.9 & 0.25 \\
\hline HSB 65 & 3682470.5 & 439134.0 & 242.4 & 212.4 & 270.4 & 47 & 237.3 & 230.1 & 7.2 & 1.57 & 232.7 & 0.23 \\
\hline
\end{tabular}




\begin{tabular}{|c|c|c|c|c|c|c|c|c|c|c|c|c|}
\hline Well ID & UTMN & UTME & Sz top & Szbot. & Gr. Elev. & No. & Max. & Min. & Range & Std. Dev. & Mean WL & StdErr_Mean \\
\hline HSB 66 & 3682201.8 & 438762.9 & 228.1 & 198.1 & 278.1 & 58 & 227.9 & 210.9 & 17.0 & 2.13 & 225.0 & 0.28 \\
\hline HSB 67 & 3682242.5 & 439297.2 & 230.7 & 200.7 & 235.7 & 54 & 226.4 & 211.1 & 15.3 & 1.98 & 223.4 & 0.27 \\
\hline HSB 68 & 3681975.0 & 438917.8 & 243.3 & 213.3 & 248.3 & 33 & 223.4 & 220.0 & 3.4 & 0.8 & 221.3 & 0.14 \\
\hline HSB 69 & 3681903.3 & 438809.5 & 229.0 & 199.0 & 234.0 & 53 & 220.9 & 218.1 & 2.8 & 0.73 & 219.4 & 0.10 \\
\hline HSB 70 & 3682035.8 & 438442.9 & 235.7 & 205.7 & 240.7 & 46 & 233.7 & 215.7 & 18.0 & 2.92 & 223.9 & 0.43 \\
\hline HSB 71 & 3682016.0 & 438276.5 & 234.8 & 204.8 & 239.8 & 45 & 230.9 & 213.5 & 17.4 & 3.12 & 224.4 & 0.47 \\
\hline HSB 830 & 3682304.5 & 439318.8 & 228.7 & 198.7 & 234.4 & 49 & 227.5 & 222.7 & 4.8 & 0.99 & 224.7 & 0.14 \\
\hline HSB $84 \mathrm{D}$ & 3681889.8 & 438772.0 & 219.5 & 199.5 & 225.7 & 45 & 220.7 & 217.7 & 3.0 & 0.72 & 218.8 & 0.11 \\
\hline HSB 86D & 3682057.5 & 438516.7 & 236.6 & 206.6 & 260.7 & 47 & 227.5 & 220.6 & 6.9 & 1.43 & 223.2 & 0.21 \\
\hline HSB $100 \mathrm{D}$ & 3682449.3 & 439286.9 & 236.9 & 216.9 & 257.9 & 54 & 237.9 & 231.2 & 6.8 & 1.28 & 233.3 & 0.17 \\
\hline "HSBTOOPD & 3681861.0 & 438804.1 & 214.9 & 195.0 & 224.0 & 1 & 216.9 & 216.9 & 0.0 & 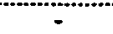 & 216.9 & \\
\hline HSBIOTD & 3682394.3 & 439250.8 & 236.1 & 216.1 & 256.4 & 53 & 234.8 & 229.1 & 5.7 & 1.06 & 230.5 & 0.15 \\
\hline $\mathrm{HAOB} 102 \mathrm{O}$ & 3682347.0 & 439209.3 & 236.3 & 216.3 & 256.3 & 45 & 230.9 & 226.6 & 4.3 & 0.87 & 228.1 & 0.13 \\
\hline HSBIO3D & 3682243.3 & 439255.5 & 233.7 & 213.7 & 245.4 & 49 & 229.3 & 223.8 & 5.5 & 1 & 225.4 & 0.14 \\
\hline HSBTOAD & 3682146.8 & 439235.5 & 230.6 & 210.6 & 245.6 & 48 & 227.8 & 218.7 & 9.1 & 1.31 & 224.7 & 0.19 \\
\hline HISBTOSD & 3682132.0 & 439171.4 & 231.8 & 211.8 & 247.2 & 50 & 228.2 & 223.3 & 5.0 & 1.06 & 225.1 & 0.15 \\
\hline HSBIOED & 3682157.5 & 439065.2 & 230.7 & 210.7 & 250.7 & 45 & 229.4 & 223.9 & 5.5 & 1.04 & 225.6 & 0.16 \\
\hline HASBIOTD & 3682108.0 & 439013.5 & 235.1 & 215.1 & 260.0 & 48 & 227.1 & 222.8 & 4.3 & 0.98 & 224.5 & 0.14 \\
\hline HSBIOED & 3682058.3 & 438949.3 & 232.0 & 212.0 & 264.0 & 39 & 225.0 & 221.7 & 3.3 & 0.85 & 223.2 & 0.14 \\
\hline HSB 1090 & 3682011.0 & 438885.7 & 233.0 & 213.0 & 259.0 & 36 & 225.6 & 221.3 & 4.3 & 0.92 & 222.7 & 0.15 \\
\hline HOSBIIOO & 3681997.3 & 438815.3 & 231.4 & 211.4 & 253.4 & 47 & 224.7 & 219.5 & 5.2 & 1.05 & 221.9 & 0.15 \\
\hline HSBITAE & 3682000.5 & 438743.3 & 231.7 & 211.7 & 253.7 & 47 & 224.5 & 218.4 & 6.2 & 1.1 & 221.9 & 0.16 \\
\hline HSBII2E & 3682042.3 & 438679.7 & 231.7 & 211.7 & 252.7 & 50 & 225.3 & 220.8 & 4.6 & 1.11 & 222.4 & 0.16 \\
\hline HSB113D & 3682033.5 & 438597.4 & 236.2 & 216.2 & 258.7 & 50 & 225.9 & 220.4 & 5.5 & 1.35 & 222.3 & 0.19 \\
\hline HSBIIAD & 3682065.3 & 438551.9 & 232.8 & 212.8 & 261.8 & 46 & 226.9 & 220.8 & 6.1 & 1.45 & 223.1 & 0.21 \\
\hline HSB115D & 3682099.8 & 438502.2 & 233.9 & 213.9 & 266.9 & 52 & 228.2 & 221.4 & 6.8 & 1.65 & 223.8 & 0.23 \\
\hline HSBIIOD & 3682148.8 & 438447.2 & 234.5 & 214.5 & 254.5 & 47 & 243.5 & 222.8 & 20.7 & 4 & 226.1 & 0.58 \\
\hline HSBI17O & 3681962.3 & 438269.1 & 220.3 & 200.3 & 235.3 & 52 & 231.4 & 219.6 & 11.8 & 2.75 & 223.9 & 0.38 \\
\hline HSBI25D & 3682269.3 & 439337.8 & 219.4 & 199.4 & 229.4 & 48 & 222.8 & 220.1 & 2.7 & 0.76 & 221.1 & 0.11 \\
\hline HOSB1260 & 3681802.8 & 439144.4 & 200.5 & 190.5 & 210.5 & 49 & 206.1 & 204.0 & 2.2 & 0.54 & 205.1 & 0.08 \\
\hline HSBI2ZD & 3681878.5 & 438945.4 & 217.8 & 197.8 & 223.8 & 47 & 219.7 & 217.1 & 2.6 & 0.66 & 218.2 & 0.10 \\
\hline HSBI29D & 3681728.8 & 438419.5 & 205.2 & 185.2 & 212.7 & 48 & 210.5 & 206.6 & 3.9 & 0.94 & 208.5 & 0.14 \\
\hline HSB130D & 3681381.5 & 438501.9 & 202.1 & 182.1 & 216.1 & 49 & 201.4 & 198.4 & 3.0 & 0.61 & 200.1 & 0.09 \\
\hline HSB1310 & 3681686.5 & 439123.9 & 205.7 & 195.7 & 209.8 & 50 & 207.0 & 203.8 & 3.2 & 0.79 & 205.1 & 0.11 \\
\hline HSBं 320 & 3682301.0 & 439395.9 & 226.5 & 206.5 & 238.5 & 46 & 227.9 & 218.5 & 9.4 & 1.36 & 221.2 & 0.20 \\
\hline HSBI34D & 3682148.5 & 439317.3 & 225.8 & 205.8 & 235.9 & 49 & 225.2 & 220.5 & 4.7 & 1.11 & 222.1 & 0.16 \\
\hline HISB135D & 3681880.0 & 438855.5 & 219.9 & 199.9 & 229.9 & 47 & 220.1 & 217.0 & 3.1 & 0.74 & 218.2 & 0.11 \\
\hline HSBI36D & 3681896.0 & 438613.7 & 220.2 & 200.2 & 225.7 & 47 & 223.1 & 218.9 & 4.2 & 1.11 & 220.7 & 0.16 \\
\hline HSBIJTD & 3681943.8 & 438486.3 & 225.3 & 205.3 & 234.3 & 48 & 225.4 & 219.6 & 5.8 & 1.45 & 222.0 & 0.21 \\
\hline HSBIJBD & 3682082.8 & 438221.0 & 228.1 & 208.1 & 250.1 & 48 & 229.3 & 215.4 & 13.9 & 2.44 & 223.6 & 0.35 \\
\hline HSBI39D & 3681964.3 & 439107.7 & 226.7 & 206.7 & 231.7 & 48 & 228.9 & 220.1 & 8.8 & 1.76 & 222.5 & 0.25 \\
\hline HSBI $40 D$ & 3681546.3 & 439101.5 & 214.1 & 194.1 & 234.1 & 39 & 219.1 & 206.5 & 12.6 & 2.36 & 213.5 & 0.38 \\
\hline HSBI41D & 3682297.3 & 439538.6 & 237.8 & 217.8 & 252.8 & 41 & 249.9 & 233.4 & 16.4 & 4.61 & 240.7 & 0.72 \\
\hline HSB142D & 3681754.3 & 437794.0 & 199.7 & 189.7 & 201.7 & 38 & 206.0 & 196.4 & 9.7 & 1.65 & 198.2 & 0.27 \\
\hline HOSBI 43D & 3681783.3 & 437502.0 & 216.9 & 196.9 & 220.9 & 39 & 215.7 & 211.2 & 4.5 & 1.14 & 213.1 & 0.18 \\
\hline HSBIA6D & 3681999.8 & 439499.8 & 224.1 & 204.0 & 251.1 & 40 & 227.6 & 209.9 & 17.7 & 3.07 & 221.9 & 0.49 \\
\hline HSB 1470 & 3682344.8 & 438235.2 & 235.2 & 215.2 & 265.2 & 40 & 237.4 & 227.4 & 10.0 & 2.39 & 231.3 & 0.38 \\
\hline HSBI $48 D$ & 3681361.0 & 438782.3 & 218.1 & 198.1 & 249.1 & 42 & 217.2 & 211.7 & 5.6 & 1.43 & 213.2 & 0.22 \\
\hline HISB149D & 3681997.3 & 439046.6 & 227.0 & 207.0 & 238.0 & 39 & 226.8 & 212.3 & 14.5 & 3.43 & 2222 & 0.55 \\
\hline HSB 150D & 3682336.8 & 439329.7 & 226.9 & 206.9 & 236.9 & 42 & 233.1 & 224.0 & 9.1 & 2.52 & 226.6 & 0.39 \\
\hline HSB151D & 3681821.5 & 437946.0 & 207.6 & 197.6 & 211.6 & 39 & 210.8 & 205.2 & 5.6 & 1.33 & 207.2 & 0.21 \\
\hline HOSB152D & 3681638.8 & 438205.6 & 207.0 & 197.0 & 212.0 & 7 & 209.3 & 204.2 & 5.1 & 1.72 & 205.7 & 0.65 \\
\hline HSL ID & 3682498.3 & 439299.5 & 239.8 & 219.8 & 261.8 & 30 & 238.3 & 227.7 & 10.6 & 1.86 & 234.9 & 0.34 \\
\hline HSL 20 & 3682590.5 & 439420.3 & 245.3 & 225.2 & 263.3 & 31 & 244.3 & 239.5 & 4.8 & 1.24 & 241.5 & 0.22 \\
\hline HISL 30 & 3682667.8 & 439494.9 & 253.8 & 233.7 & 265.6 & 33 & 261.0 & 247.7 & 13.4 & 2.35 & 250.0 & 0.41 \\
\hline HSL 40 & 3682789.5 & 439557.6 & 265.1 & 245.0 & 271.1 & 33 & 264.4 & 257.7 & 6.7 & 1.73 & 261.4 & 0.30 \\
\hline HSL $5 \mathrm{D}$ & 3682846.3 & 439579.4 & 267.7 & 247.8 & 274.7 & 29 & 269.8 & 258.2 & 11.7 & 2.94 & 265.7 & 0.55 \\
\hline HSL $6 D$ & 3682904.8 & 439609.1 & 264.0 & 243.9 & 277.7 & 35 & 263.4 & 256.7 & 6.7 & 1.78 & 259.5 & 0.30 \\
\hline HOLL & 3682942.8 & 439653.8 & 262.4 & 242.3 & 281.4 & 32 & 262.4 & 257.2 & 5.2 & 1.47 & 259.4 & 0.26 \\
\hline HISL BD & 3683016.8 & 439748.4 & 268.4 & 248.4 & 286.4 & 37 & 263.6 & 258.1 & 5.6 & 1.35 & 260.5 & 0.22 \\
\hline HSS 3D & 3682569.5 & 441427.9 & 282.6 & 262.6 & 308.1 & 26 & 287.9 & 2722 & 15.7 & 3.31 & 282.2 & 0.65 \\
\hline HTF 5 & 3682875.0 & 440225.8 & 284.3 & 264.3 & 304.3 & 16 & 279.8 & 266.2 & 13.7 & 3.29 & 277.0 & 0.82 \\
\hline HTF 6 & 3682864.0 & 440278.3 & 283.6 & 263.6 & 303.6 & 16 & 279.4 & 265.6 & 13.8 & 3.11 & 275.9 & 0.78 \\
\hline Hif 7 & 3682811.3 & 440272.9 & 283.5 & 263.5 & 303.5 & 22 & 281.3 & 272.2 & 9.1 & 1.82 & 276.2 & 0.39 \\
\hline HTF 8 & 3682819.5 & 440211.6 & 283.6 & 263.6 & 303.9 & 16 & 276.2 & 264.3 & 11.9 & 3.04 & 273.5 & 0.76 \\
\hline HTF 13 & 3682895.8 & 440013.1 & 282.6 & 262.6 & 322.6 & 25 & 277.4 & 270.4 & 7.0 & 1.68 & 274.4 & 0.34 \\
\hline HTF 14 & 3682874.0 & 439982.2 & 281.9 & 261.9 & 321.9 & 19 & 282.2 & 2710 & 11.2 & 2.3 & 273.7 & 0.53 \\
\hline HTF 15 & 3682815.5 & 439983.7 & 280.7 & 260.7 & 320.7 & 28 & 275.7 & 271.0 & 4.7 & 1.3 & 273.6 & 0.25 \\
\hline
\end{tabular}




\begin{tabular}{|c|c|c|c|c|c|c|c|c|c|c|c|c|}
\hline Well ID & UTMN & UTME & Sz top & Szbot. & Gr. Elev. & No. & Max. & Min. & Range & Std. Dev. & Mean WL & StdEr,_Mean \\
\hline HTF 16 & 3683033.5 & 440050.1 & 268.3 & 248.3 & 298.4 & 20 & 274.3 & 267.5 & 6.8 & 2.06 & 270.0 & 0.46 \\
\hline НТF 17 & 3683007.8 & 439781.6 & 258.4 & 238.4 & 288.4 & 27 & 273.2 & 253.7 & 19.5 & 3.37 & 262.6 & 0.65 \\
\hline HTF 18 & 3682810.0 & 439938.8 & 271.7 & 251.7 & 321.7 & 28 & 274.5 & 268.7 & 5.8 & 1.51 & 271.9 & 0.29 \\
\hline HTF 19 & 3682816.5 & 439879.9 & 265.7 & 245.7 & 322.7 & 28 & 271.8 & 265.8 & 6.0 & 1.49 & 269.2 & 0.28 \\
\hline HTF 20 & 3682859.8 & 439851.1 & 271.9 & 251.9 & 322.9 & 28 & 270.9 & 259.8 & 71.1 & 2.2 & 268.0 & 0.42 \\
\hline $\mathrm{HTF} 22$ & 3682948.0 & 440339.8 & 271.4 & 251.4 & 331.4 & 26 & 278.7 & 2723 & 6.4 & 1.79 & 275.7 & 0.35 \\
\hline HTF 23 & 3682968.8 & 440368.6 & 276.8 & 256.8 & 331.8 & 27 & 278.0 & 266.7 & 11.3 & 2.31 & 274.7 & 0.44 \\
\hline НTF 24 & 3682987.5 & 440394.6 & 277.8 & 257.8 & 331.8 & 25 & 277.3 & 270.9 & 6.4 & 1.74 & 274.4 & 0.35 \\
\hline HTF 25 & 3682976.3 & 440450.6 & 272.5 & 252.5 & 332.5 & 26 & 283.8 & 270.5 & 13.3 & 3.06 & 275.0 & 0.60 \\
\hline HTF 26 & 3682927.8 & 440453.3 & 275.5 & 255.5 & 333.5 & 26 & 284.0 & 271.7 & 12.3 & 2.82 & 275.8 & 0.55 \\
\hline HTF 27 & 3682892.0 & 440420.9 & 279.1 & 259.1 & 331.1 & 27 & 292.9 & 267.1 & 25.8 & 4.23 & 277.0 & 0.81 \\
\hline HIF 28 & 3682871.5 & 440381.3 & 271.9 & 251.9 & 331.9 & 25 & 278.6 & 273.7 & 4.9 & 1.35 & 276.0 & 0.27 \\
\hline HIF 29 & 36828903 & 440329.6 & 289.9 & 259.9 & 331.9 & 25 & 279.2 & 2727 & 6.5 & 1.54 & 275.8 & 0.31 \\
\hline HTF 32 & 3682874.8 & 440489.0 & 271.1 & 251.1 & 327.1 & 27 & 278.0 & 252.2 & 25.8 & 4.61 & 274.1 & 0.89 \\
\hline HTF 34 & 3682790.8 & 440237.5 & 271.7 & 251.7 & 303.7 & 15 & 278.5 & 273.3 & 5.2 & 1.25 & 276.1 & 0.32 \\
\hline HWS IA & 3679143.0 & 438466.8 & 255.2 & 225.2 & 323.2 & 23 & 248.3 & 2422 & 6.1 & 2.1 & 244.9 & 0.44 \\
\hline HWS 2 & 3679138.5 & 438512.0 & 245.3 & 215.3 & 320.3 & 23 & 249.1 & 242.9 & 6.3 & 2.26 & 245.5 & 0.47 \\
\hline HXB 4D & 3678535.8 & 439806.8 & 254.9 & 234.9 & 304.4 & 19 & 257.2 & 251.0 & 6.2 & 2.05 & 254.1 & 0.47 \\
\hline$H \times B 5 D$ & 3678492.3 & 439798.1 & 254.2 & 234.2 & 306.2 & 17 & 256.4 & 250.5 & 5.9 & 2 & 253.5 & 0.49 \\
\hline IDB 4 & 3686341.5 & 442531.3 & 259.6 & 239.6 & 314.8 & 16 & 257.8 & 244.4 & 13.3 & 4.3 & 249.9 & 1.08 \\
\hline IDB 5 & 3686304.0 & 442771.9 & 255.1 & 235.1 & 320.1 & 18 & 255.0 & 2418 & 13.2 & 379 & 247.7 & 0.89 \\
\hline IDB 6 & 36855554.5 & 443233.0 & 260.7 & 240.7 & 317.0 & 18 & 264.3 & 246.7 & 17.6 & 4.92 & 258.2 & 1.16 \\
\hline IDB 7 & 3685610.8 & 442885.2 & 261.4 & 241.4 & 311.4 & 18 & 265.4 & 253.6 & 11.8 & 3.82 & 259.5 & 0.90 \\
\hline IDB 8 & 3685710.8 & 443796.8 & 249.3 & 229.3 & 291.3 & 18 & 245.6 & 234.8 & 10.8 & 2.88 & 239.5 & 0.68 \\
\hline $\mathrm{IDP} 4$ & 3681475.8 & 432389.4 & 199.6 & 189.5 & 238.6 & 14 & 196.3 & 189.6 & 6.6 & 1.96 & 193.2 & 0.52 \\
\hline IDP 5 & 3681591.0 & 432180.8 & 206.6 & 186.4 & 251.7 & 18 & 203.3 & 192.1 & 11.3 & 3.4 & 198.2 & 0.80 \\
\hline IDP 6 & 3681730.5 & 432065.6 & 209.1 & 184.5 & 259.6 & 18 & 206.5 & 196.8 & 9.7 & 3.35 & 201.3 & 0.79 \\
\hline IDP 7 & 3681899.3 & 432118.2 & 208.6 & 188.6 & 246.6 & 18 & 206.1 & 196.0 & 10.1 & 3.53 & 201.1 & 0.83 \\
\hline IDP 8 & 3682050.8 & 432181.4 & 204.5 & 185.4 & 262.5 & 18 & 204.9 & 188.3 & 16.6 & 4.74 & 198.9 & 1.12 \\
\hline IDP 9 & 3682108.0 & 431633.2 & 208.0 & 188.0 & 270.0 & 18 & 209.5 & 198.2 & 11.3 & 3.87 & 203.6 & 0.91 \\
\hline $10 Q 4$ & 3681214.0 & 431867.9 & 205.6 & 185.6 & 263.5 & 18 & 203.5 & 192.9 & 10.6 & 3.25 & 198.2 & 0.77 \\
\hline IDQ 5 & 3681147.3 & 431963.7 & 207.5 & 187.4 & 265.0 & 12 & 200.0 & 194.1 & 5.9 & 1.75 & 197.0 & 0.51 \\
\hline IDQ 6 & 3681141.5 & 432136.6 & 202.1 & 181.9 & 256.1 & 19 & 198.5 & 188.1 & 10.3 & 3.09 & 193.6 & 0.71 \\
\hline $10 Q 7$ & 3681162.3 & 432323.9 & 194.8 & 174.6 & 238.8 & 13 & 191.7 & 183.5 & 8.3 & 2.15 & 187.9 & 0.60 \\
\hline IDQ 8 & 3680966.0 & 431280.2 & 200.4 & 180.4 & 240.7 & 9 & 191.6 & 188.2 & 3.3 & 1.05 & 189.3 & 0.35 \\
\hline 1009 & 3680637.3 & 431280.4 & 1939 & 1739 & 2343 & 7 & 183.2 & 180.1 & 3.1 & 1.21 & 181.8 & 0.46 \\
\hline IDQ 10 & 3680411.3 & 431277.7 & 185.7 & 165.7 & 234.7 & 13 & 176.7 & 170.4 & 6.4 & 1.63 & 174.0 & 0.45 \\
\hline IDO 11 & 3680177.0 & 431874.6 & 134.8 & 129.7 & 206.8 & 3 & 140.9 & 135.5 & 5.4 & 2.78 & 137.9 & 1.61 \\
\hline IDQ 12 & 3680985.5 & 432181.3 & 184.9 & 1649 & 240.5 & 12 & 191.2 & 183.6 & 7.6 & 2.04 & 187.8 & 0.59 \\
\hline K 301P & 3674676.5 & 437801.2 & 201.0 & 194.4 & 261.0 & 36 & 208.9 & 202.3 & 6.6 & 1.94 & 204.9 & 0.32 \\
\hline $\mathrm{KAB} 1$ & 36743790 & 438047.1 & 2240 & 1940 & 264.0 & 23 & 209.2 & 201.7 & 7.6 & 2.12 & 205.0 & 0.44 \\
\hline $\mathrm{KAB} 2$ & 3674284.3 & 438251.0 & 228.6 & 198.6 & 258.6 & 24 & 219.6 & 204.2 & 15.4 & 4.16 & 2089 & 0.85 \\
\hline $\mathrm{KAB} 3$ & 3674071.3 & 438270.6 & 223.0 & 1930 & 248.0 & 21 & 208.1 & 198.9 & 9.3 & 2.47 & 203.0 & 0.54 \\
\hline $\mathrm{KAB} 4$ & 3674234.8 & 437977.7 & 217.0 & 187.0 & 252.0 & 22 & 206.8 & 197.6 & 9.2 & 2.52 & 202.0 & 0.54 \\
\hline KAC 1 & 3674889.8 & 438691.1 & 229.0 & 199.0 & 264.0 & 28 & 225.5 & 215.4 & 10.2 & 2.57 & 219.8 & 0.49 \\
\hline KAC 2 & 36749228 & 438690.6 & 225.4 & 195.4 & 255.4 & 27 & 226.8 & 216.6 & 10.2 & 2.61 & 222.2 & 0.50 \\
\hline KAC 3 & 3674917.8 & 438711.7 & 225.8 & 195.8 & 255.8 & 28 & 226.7 & 218.4 & 8.3 & 2.21 & 222.6 & 0.42 \\
\hline KAC 5 & 3674906.5 & 438717.0 & 224.3 & 204.3 & 256.8 & 28 & 226.7 & 218.4 & 8.4 & 2.36 & 222.5 & 0.45 \\
\hline KAC 6 & 3674897.0 & 438715.3 & 224.6 & 204.6 & 257.1 & 27 & 226.7 & 218.2 & 8.5 & 2.41 & 222.5 & 0.46 \\
\hline KAC 7 & 3674903.5 & 438665.8 & 2230 & 203.0 & 263.0 & 29 & 224.1 & 215.5 & 8.6 & 2.22 & 219.6 & 0.41 \\
\hline $\mathrm{KCB} 1$ & 3674405.8 & 437878.1 & 213.6 & 183.6 & 258.6 & 28 & 209.1 & 200.1 & 9.0 & 2.29 & 204.0 & 0.43 \\
\hline $\mathrm{KCB} 2$ & 3674417.0 & 437799.8 & 217.7 & 187.7 & 252.7 & 27 & 208.1 & 192.5 & 15.6 & 3.95 & 202.3 & 0.76 \\
\hline KCB 3 & 3674333.8 & 437785.8 & 214.1 & 184.1 & 246.1 & 29 & 206.9 & 198.1 & 8.8 & 2.2 & 201.7 & 0.41 \\
\hline $\mathrm{KCB} 4$ & 3674320.0 & 437862.3 & 218.9 & 188.9 & 253.9 & 9 & 2066 & 202.1 & 4.5 & 1.6 & 2040 & 0.53 \\
\hline KCB 5 & 3674303.8 & 437789.4 & 209.3 & 189.3 & 246.3 & 7 & 202.1 & 197.9 & 4.2 & 1.54 & 200.4 & 0.58 \\
\hline KCB 6 & 3674357.5 & 437756.8 & 208.7 & 188.7 & 245.7 & 6 & 202.5 & 198.1 & 4.4 & 1.73 & 201.0 & 0.71 \\
\hline KCB 7 & 3674453.3 & 437952.5 & 216.5 & 196.5 & 265.5 & 8 & 207.2 & 203.3 & 3.9 & 1.68 & 2053 & 0.59 \\
\hline $\mathrm{KOB} 1$ & 3674714.8 & 437993.4 & 205.8 & 184.8 & 270.8 & 42 & 211.7 & 205.6 & 6.1 & 1.61 & 208.2 & 0.25 \\
\hline $\mathrm{KOB} 2$ & 3674646.5 & 437973.6 & 203.5 & 182.5 & 270.6 & 42 & 210.7 & 204.1 & 6.6 & 1.7 & 206.8 & 0.26 \\
\hline KDB 3 & 3674646.0 & 438031.4 & 2054 & 184.2 & 270.5 & 46 & 211.5 & 204.9 & 6.6 & 1.65 & 207.6 & 0.24 \\
\hline KDB 4 & 3674600.5 & 437972.7 & 209.2 & 189.2 & 271.0 & 14 & 208.0 & 205.5 & 2.5 & 0.67 & 206.3 & 0.18 \\
\hline KDB 5 & 3674644.8 & 437896.3 & 208.5 & 188.5 & 268.4 & 21 & 207.6 & 203.1 & 4.5 & 1.27 & 205.0 & 0.28 \\
\hline KDT 10 & 36747320 & 437963.5 & 213.7 & 193.7 & 270.7 & 19 & 211.1 & 205.3 & 5.8 & 1.63 & 208.1 & 0.37 \\
\hline KRB 8 & 3674900.3 & 437811.7 & 215.8 & 195.8 & 265.8 & 7 & 209.4 & 207.5 & 1.9 & 0.78 & 208.4 & 0.29 \\
\hline KRB $16 D$ & 3674914.8 & 437834.4 & 211.5 & 191.5 & 266.5 & 18 & 210.8 & 207.2 & 3.7 & 1.05 & 209.3 & 0.25 \\
\hline KRB 170 & 3674980.8 & 437636.2 & 206.8 & 186.8 & 282.1 & 18 & 208.2 & 204.1 & 4.1 & 1.12 & 205.9 & 0.26 \\
\hline KRB $18 D$ & 3675026.5 & 437638.0 & 205.8 & 185.8 & 280.8 & 18 & 2062 & 2028 & 3.4 & 0.9 & 204.5 & 0.21 \\
\hline KRB 19D & 3675062.5 & 437657.9 & 206.8 & 186.8 & 279.8 & 18 & 205.3 & 202.1 & 3.2 & 0.79 & 203.7 & 0.19 \\
\hline
\end{tabular}




\begin{tabular}{|c|c|c|c|c|c|c|c|c|c|c|c|c|}
\hline Well ID & UTMN & UTME & Sz top & Szbot. & Gr. Elev. & No. & Max. & Min. & Range & Std. Dev. & Mean WL & StdErr_Mean \\
\hline KAP 1 & 3675203.3 & 438408.8 & 237.0 & 207.0 & 262.0 & 28 & 222.3 & 208.8 & 13.6 & 2.61 & 218.5 & 0.49 \\
\hline KÄ 2 & 3675231.0 & 438467.8 & 229.2 & 199.2 & 254.2 & 25 & 222.6 & 215.5 & 7.1 & 1.95 & 219.4 & 0.39 \\
\hline $\mathrm{KAP} 3$ & 3675192.0 & 438546.3 & 237.5 & 207.5 & 252.5 & 24 & 223.6 & 214.1 & 9.5 & 2.34 & 219.5 & 0.48 \\
\hline$K A P 4$ & 3675180.0 & 438470.6 & 218.7 & 188.7 & 253.7 & 27 & 221.9 & 215.0 & 69 & 1.85 & 218.6 & 0.36 \\
\hline KRP 6 & 3675076.3 & 438409.1 & 213.1 & 203.1 & 267.9 & 7 & 217.7 & 217.2 & 0.5 & 0.21 & 217.4 & 0.08 \\
\hline KRP 7 & 3675057.8 & 438288.6 & 213.2 & 203.1 & 267.9 & 6 & 2156 & 215.2 & 0.4 & 0.18 & 215.4 & 0.07 \\
\hline$K S B$ & 36746023 & 4378420 & 205.6 & 175.6 & 265.6 & 48 & 208.5 & 200.2 & 8.3 & 2.01 & 203.8 & 0.29 \\
\hline $\mathrm{KSB} 2$ & 3674555.0 & 437837.4 & 203.8 & 173.8 & 263.8 & 51 & 208.3 & 200.5 & 7.8 & 2.06 & 203.5 & 0.29 \\
\hline KSB 3 & 3674568.8 & 437798.0 & 199.7 & 169.7 & 259.7 & 49 & 207.5 & 199.8 & 7.7 & 2.09 & 2028 & 0.30 \\
\hline$K S B \quad 4 A$ & 36746170 & 4378124 & 1996 & 169.6 & 259.1 & 47 & 208.2 & 193.5 & 14.6 & 3.73 & 2029 & 0.54 \\
\hline $\mathrm{KSB} 5 \mathrm{D}$ & 3674659.3 & 437862.2 & 214.5 & 194.5 & 267.1 & 7 & 205.5 & 203.5 & 1.9 & 0.98 & 204.5 & 0.37 \\
\hline KSM ID & 3674731.3 & 437944.7 & 213.7 & 193.7 & 270.2 & 27 & 209.8 & 205.1 & 4.7 & 1.21 & 208.2 & 0.23 \\
\hline KSSID & 3673127 & 439070.8 & 177.5 & 157.4 & 228.1 & 27 & 178.2 & 170.4 & 78 & 229 & 174.4 & 0.44 \\
\hline KSS 20 & 3672931.5 & 439295.7 & 164.7 & 144.6 & 1904 & 27 & 168.3 & 160.9 & 7.4 & 2.2 & 164.8 & 0.42 \\
\hline KSS 30 & 3672948.0 & 439400.9 & 159.3 & 139.3 & 183.2 & 27 & 167.8 & 154.3 & 13.5 & 2.93 & 164.0 & 0.56 \\
\hline$\angle A C 1$ & 3674497.5 & 442257.1 & 221.1 & 191.1 & 236.1 & 26 & 223.8 & 211.8 & 12.0 & 2.97 & 2169 & 0.58 \\
\hline$\angle A C 2$ & 3674511.3 & 442228.7 & 223.4 & 193.4 & 2384 & 28 & 223.8 & 2029 & 20.9 & 3.86 & 2164 & 0.73 \\
\hline $\operatorname{LAC} 3$ & 36746648 & 4422312 & 220.7 & 190.7 & 235.7 & 28 & 223.6 & 211.8 & 11.8 & 285 & 217.0 & 0.54 \\
\hline LAC 4 & 3674482.5 & 442249.8 & .215 .3 & 185.3 & 235.3 & 26 & 223.5 & 193.3 & 30.2 & 5.36 & 215.6 & .1 .05 \\
\hline LACEDO & 36745293 & 442245.2 & 227.8 & 207.9 & 239.3 & 7 & 223.8 & 217.6 & 6.2 & 21 & 219.5 & 0.79 \\
\hline$\angle A C 6 D O$ & 3674477.0 & 442219 & 2217 & 201.7 & 237.7 & 6 & 2232 & 216.8 & 64 & 2.27 & 219.0 & 0.93 \\
\hline IAC & 3674431.3 & 442230.4 & 224.8 & 204.9 & 239.8 & 6 & 2225 & 215.5 & 70 & 2.38 & 2181 & 0.97 \\
\hline LAC 8DU & 36746643 & 442274.9 & 219.8 & 199.8 & 234.5 & 6 & 2224 & 215.7 & 6.7 & 2.29 & 218.1 & 0.93 \\
\hline $\operatorname{LCO}{ }_{i}$ & 3674422.8 & 442175.4 & 225.8 & 195.8 & 238.8 & 27 & 221.2 & 206.7 & 14.5 & 3.4 & 215.2 & 0.65 \\
\hline$\angle C O=$ & 3674667.5 & 442175.1 & 226.6 & 196.6 & 239.6 & 28 & 220.9 & 207.8 & 13.1 & 3.49 & 215.3 & 0.66 \\
\hline $\operatorname{LCO} 3$ & 3674451.8 & 442212.9 & 226.3 & 196.3 & 239.3 & 26 & 235.2 & 224.4 & 10.8 & 281 & 229.5 & 0.55 \\
\hline $2 \mathrm{CO} 4$ & 3674409.5 & 442214.6 & 2223 & 1923 & 235.3 & 29 & 219.3 & 203.1 & 16.2 & 3.58 & 213.0 & 0.66 \\
\hline$\angle C O B D$ & 3674590.8 & 442205.4 & 226.1 & 211.1 & 243.7 & 6 & 224.5 & 218.7 & 5.8 & 2.05 & 220.6 & 0.84 \\
\hline$[\mathrm{DB} 1$ & 3674526.5 & 441961.5 & 2150 & 1850 & 250.5 & 37 & 220.8 & 211.5 & 9.3 & 2.27 & 216.7 & 0.37 \\
\hline $\mathrm{ZOB} 2$ & 3674591.0 & 441987.7 & 214.5 & 184.5 & 250.5 & 40 & 223.3 & 213.6 & 9.7 & 2.18 & 218.8 & 0.34 \\
\hline $\mathrm{ZOB} 3$ & 3674559.8 & 441912.9 & 219.3 & 199.3 & 251.2 & 22 & 220.8 & 216.3 & 4.4 & 1.17 & 2180 & 0.25 \\
\hline$\angle D B 4$ & 3674462.3 & 441913.6 & 220.7 & 2007 & 247.7 & 21 & 218.2 & 214.4 & 3.8 & 1.04 & 215.9 & 0.23 \\
\hline HFW 6 & 3683090 & 433712.3 & 160.4 & 141.1 & 170.2 & 28 & 156.8 & 147.5 & 93 & 1.95 & 1543 & 0.37 \\
\hline$\angle F W \quad 6 R$ & 3683050.0 & 4337229 & 154.5 & 134.5 & 168.2 & 5 & 153.8 & 1528 & 11 & 0.4 & 153.4 & 0.18 \\
\hline IFW 7 & 3683046.8 & 433772.3 & 159.8 & 140.5 & 169.6 & 23 & 1548 & 150.2 & 4.7 & 1.13 & 1522 & 0.24 \\
\hline LFW 8 & 3682995.8 & 433845.8 & 159.2 & 139.9 & 169.0 & 30 & 152.5 & 148.2 & 4.3 & 1.18 & 150.2 & 0.22 \\
\hline ZFW 8 & 36829750 & 433860.6 & 155.1 & 135.1 & 168.7 & 5 & 150.1 & 148.9 & 12 & 0.45 & 449.6 & 0.20 \\
\hline $\mathrm{LFW} 10 \mathrm{~A}$ & 3683172.0 & 433913.5 & 159.2 & 129.2 & 174.2 & 32 & 155.2 & 145.0 & 10.3 & 2.19 & 151.8 & 0.39 \\
\hline TFW & 368350.5 & 433825.1 & 161.2 & 1312 & 177.2 & 27 & 158.3 & 152.5 & 5.8 & 1.47 & 155.9 & 0.28 \\
\hline ifw 17 & 3683170.5 & 433790.8 & 158.5 & 128.5 & 176.5 & 28 & 157.2 & 147.2 & 10.1 & 2.9 & 154.0 & 0.55 \\
\hline iFW 18 & 36831378 & 433759.0 & 160.1 & 130.1 & 174.1 & 30 & 157.5 & 144.6 & 129 & 3 & 153.8 & 0.55 \\
\hline ZFW 19 & 3683138.8 & 433636.1 & 160.0 & 130.0 & 175.0 & 29 & 160.7 & 153.4 & 7.3 & 1.61 & 156.4 & 0.30 \\
\hline LFW 20 & 3683288 & 433666.5 & 165.0 & 135.0 & 179.0 & 28 & 162.0 & 156.3 & 5.8 & 1.61 & 159.4 & 0.30 \\
\hline LFW 21 & 3683163.3 & 434000.5 & 158.9 & 128.9 & 173.9 & 31 & 153.7 & 139.9 & 13.8 & 3.15 & 149.5 & 0.57 \\
\hline IFW 22 & 36832060 & 4340357 & 152.4 & 1224 & 1724 & 30 & 155.5 & 148.5 & 7.0 & 1.65 & 1516 & 0.30 \\
\hline $4 F 23$ & 3683236.3 & 434063.0 & 155.1 & 125.1 & 170.1 & 29 & 156.4 & 1326 & 23.8 & 4.01 & 1516 & 0.74 \\
\hline LFW'24 & 36833200 & 4340264 & 154.5 & 124.5 & 169.5 & 29 & 159.2 & 150.6 & 8.6 & 1.83 & 154.8 & 0.34 \\
\hline LFW 25 & 3683407.0 & 433927.1 & 153.2 & 123.2 & 173.2 & 29 & 161.2 & 153.1 & 8.1 & 1.84 & 157.2 & 0.34 \\
\hline HFW & 3683434.5 & 433608.8 & 164.2 & 143.2 & 184.2 & 28 & 164.2 & 158.1 & 6.2 & 1.73 & 161.6 & 0.33 \\
\hline LFW 27 & 3633473.3 & 433566.4 & 163.9 & 1429 & 186.9 & 29 & 165.1 & 158.6 & 6.5 & 1.75 & 162.5 & .0.32 \\
\hline LFW & 36835250 & 433513.2 & 162.1 & 141.1 & 190.1 & 33 & 167.3 & 159.8 & 7.5 & 1.84 & 163.8 & 0.32 \\
\hline LFW 29 & 36835880 & 433447.8 & 164.9 & 143.9 & 1929 & 29 & 168.1 & 161.1 & 7.0 & 1.92 & 165.1 & 0.36 \\
\hline LFW $30^{\circ}$ & 3683515.0 & 433375.7 & 162.7 & 141.7 & 207.7 & 30 & 168.4 & 160.9 & 7.5 & 1.97 & 165.1 & 0.36 \\
\hline LFW 31 & 36834470 & 4333114 & 166.0 & 145.0 & 227.0 & 36 & 176.0 & 1609 & 15.1 & 26 & 1649 & 0.43 \\
\hline LFW 32 & 36683354.3 & 433404.1 & 165.3 & 144.3 & 221.3 & 34 & 165.4 & 158.9 & 6.5 & 1.66 & 162.6 & 0.28 \\
\hline LFW 33 & 36833108 & 433449.7 & 165.4 & 144.4 & 211.4 & 31 & 164.0 & 157.8 & 6.2 & 1.73 & 1613 & 0.31 \\
\hline LFW 34 & 3683263.5 & 433500.7 & 164.7 & 143.7 & 1987 & 32 & 162.6 & 156.6 & 6.0 & 1.6 & 160.1 & 0.28 \\
\hline LFW 35 & 36832860 & 433620.8 & 164.4 & 143.4 & 181.4 & 29 & 1616 & 155.5 & 6.1 & 1.61 & 159.1 & 0.30 \\
\hline IFW 36 & 3682903.3 & 433976.1 & 151.3 & 130.3 & 168.3 & 31 & 148.4 & 144.5 & 3.9 & 1.01 & 146.1 & 0.18 \\
\hline$Z \mathrm{ZFW} 36 \mathrm{R}$ & 3682892.3 & 433960.2 & 1420 & 122.0 & 166.4 & 6 & 146.5 & 144.5 & 21 & 0.76 & 1459 & 0.31 \\
\hline ZIFW 37 & 3682814.5 & 434072.8 & 150.8 & 129.8 & 167.8 & 31 & 145.1 & 140.9 & 4.1 & 1.02 & 142.9 & 0.18 \\
\hline IFW 38 & 3682920 & 434148.7 & 151.5 & 130.5 & 168.5 & 26 & 146.2 & 135.7 & 10.5 & 1.9 & 143.6 & 0.37 \\
\hline LFW 39 & 36829378 & 434190.6 & 152.2 & 131.2 & 169.2 & 26 & 146.8 & 136.3 & 10.5 & 189 & 143.8 & 0.37 \\
\hline LFW 40 & 36829783 & 434227.7 & 1522 & 1312 & 169.2 & 24 & 146.0 & 137.4 & 8.6 & 1.72 & 443 & 0.35 \\
\hline ITFW 41 & 3683033.8 & 434274.8 & 151.3 & 130.3 & 168.3 & 30 & 149.1 & 134.9 & 14.2 & 2.48 & 145.3 & 0.45 \\
\hline LFW 4AR & 3683018.8 & 434288.8 & 140.2 & 120.2 & 167.6 & 7 & 144.0 & 142.3 & 16 & 0.59 & 142.9 & 0.22 \\
\hline LFW 42 & 3683133.0 & 434167.1 & 151.2 & 130.2 & 168.2 & 26 & 151.0 & 135.9 & 15.1 & 278 & 147.8 & 0.55 \\
\hline LFW 43D & 3683559.0 & 433371.4 & 170.9 & 150.9 & 200.9 & 27 & 169.0 & 164.1 & 4.9 & 1.31 & 166.5 & 0.25 \\
\hline
\end{tabular}




\begin{tabular}{|c|c|c|c|c|c|c|c|c|c|c|c|c|}
\hline Well ID & UTMN & UTME & Sz top & Sz bot. & Gr. Elev. & No. & Max. & Min. & Range & Std. Dev. & Mean WL & StdErr_Mean \\
\hline LFW 44D & 3683046.5 & 433660.9 & 159.3 & 139.5 & 168.3 & 19 & 156.4 & 154.2 & 2.2 & 0.68 & 155.3 & 0.16 \\
\hline LFW 45D & 3682992.3 & 433745.3 & 154.7 & 134.7 & 164.4 & 25 & 153.7 & 151.2 & 2.5 & 0.71 & 1526 & 0.14 \\
\hline$\angle F W 46 D$ & 3682955.8 & 433779.8 & 1571 & 137.3 & 163.1 & 19 & 152.5 & 150.5 & 2.0 & 0.62 & 151.5 & 0.14 \\
\hline LFW 47D & 3682900.5 & 433815.4 & 154.7 & 134.9 & 159.7 & 26 & 150.4 & 148.4 & 2.0 & 0.51 & 149.4 & 0.10 \\
\hline LFW 48D & 3682954.5 & 433880.1 & 155.0 & 134.9 & 167.5 & 21 & 150.7 & 148.5 & 22 & 0.6 & 149.4 & 0.13 \\
\hline LFW 56D & 3682819.8 & 433932.8 & 151.4 & 131.3 & 155.9 & 26 & 146.6 & 1447 & 19 & 0.45 & 145.5 & 0.09 \\
\hline UFW 57D & 3682788.5 & 433997.4 & 150.4 & 130.6 & 162.9 & 21 & 144.8 & 143.4 & 1.4 & 0.39 & 144.0 & 0.09 \\
\hline ZFW 580 & 3682777.8 & 434111.8 & 147.6 & 127.5 & 165.6 & 24 & 1429 & 141.1 & 1.9 & 0.5 & 142.0 & 0.10 \\
\hline LFW 59D & 36828563 & 434188.8 & 149.3 & 129.3 & 165.3 & 23 & 145.4 & 1420 & 3.3 & 0.95 & 143.2 & 0.20 \\
\hline ZFW $60 \mathrm{D}$ & 3682681.0 & 434190.6 & 143.8 & 123.8 & 155.2 & 28 & 139.2 & 137.3 & 1.9 & 0.41 & 138.2 & 0.08 \\
\hline LFW 610 & 3682952.5 & 434275.1 & 150.4 & 130.3 & 166.4 & 21 & 146.8 & 142.3 & 4.5 & 1.3 & 144.0 & 0.28 \\
\hline LFW 620 & 3682830.3 & 434157.5 & 147.6 & 127.6 & 162.6 & 17 & 145.2 & 141.7 & 3.5 & 0.98 & 143.4 & 0.24 \\
\hline$\angle F W 630$ & 36827078 & 434113.4 & 146.4 & 126.4 & 166.2 & 17 & 141.0 & 140.0 & 1.0 & 0.27 & 140.4 & 0.07 \\
\hline LFW $66 \mathrm{D}$ & 3682836.8 & 434247.4 & 141.8 & 121.8 & 159.6 & 13 & 144.0 & 140.6 & 3.5 & 1.05 & 141.9 & 0.29 \\
\hline$\angle F W 67 D$ & 3682905.5 & 434331.6 & 140.6 & 120.6 & 155.4 & 17 & 144.8 & 140.0 & 4.8 & 1.36 & 141.8 & 0.33 \\
\hline LFW 68D & 3683009.5 & 4343832 & 144.6 & 124.6 & 159.4 & 17 & 144.9 & 140.5 & 4.4 & 1.2 & 142.3 & 0.29 \\
\hline ZFW 690 & 3682621.8 & 434150.4 & 139.0 & 119.0 & 144.0 & 17 & 138.2 & 137.5 & 0.7 & 0.22 & 137.8 & 0.05 \\
\hline HFW & 36826490 & 434258.2 & 138.3 & 118.3 & 144.3 & 10 & 136.4 & 135.3 & 1.1 & 0.37 & 135.7 & 0.12 \\
\hline IFW 71D & 3682808.8 & 434322.8 & 135.5 & 115.5 & 145.5 & 16 & 138.2 & 136.6 & 1.6 & 0.5 & 137.3 & 0.13 \\
\hline LFW $72 D$ & 3682986.0 & 434428.6 & 140.0 & 120.0 & 148.0 & 10 & 140.1 & 137.7 & 2.4 & 0.86 & 138.7 & 0.27 \\
\hline LW 740 & 3683381.0 & 433445.6 & 167.7 & 152.7 & 211.7 & 10 & 164.2 & 161.8 & 2.4 & 0.73 & 162.9 & 0.23 \\
\hline LFW 75D & 3683437.3 & 433501.9 & 166.0 & 151.0 & 196.0 & 7 & 164.4 & 1619 & 2.5 & 0.88 & 163.1 & 0.33 \\
\hline LAP 1 & 3674920.0 & 4411240 & 215.8 & 185.8 & 250.8 & 24 & 214.2 & 204.5 & 9.7 & 3.09 & 209.4 & 0.63 \\
\hline LAP 2 & 3674887.3 & 441180.2 & 214.7 & 184.7 & 254.7 & 23 & 2216 & 1957 & 258 & .4 .92 & 2103 & 1.03 \\
\hline LRP 3 & 3674854.5 & 441145.1 & 221.4 & 191.4 & 256.4 & 24 & 214.3 & 204.4 & 9.9 & 3.12 & 209.4 & 0.64 \\
\hline $\operatorname{LSB} 1$ & 3674365.5 & 442120.3 & 222.7 & 192.7 & 230.7 & 33 & 218.4 & 2057 & 127 & 2.85 & 2120 & 0.50 \\
\hline LSB 2 & 3674405.3 & 442138.0 & 225.0 & 195.0 & 233.0 & 31 & 219.6 & 206.4 & 13.2 & 2.97 & 212.8 & 0.53 \\
\hline $\operatorname{LSB} 3$ & 3674428.8 & 442085.1 & 226.6 & 196.6 & 2346 & 34 & 224.1 & 210.4 & 137 & 3.09 & 2176 & 0.53 \\
\hline ISB 4 & 3674373.5 & 442043.7 & 221.5 & 191.5 & 229.5 & 34 & 224.4 & 1986 & 25.8 & 4.63 & 217.2 & 0.79 \\
\hline MCB 2 & 36861420 & 431447.6 & 225.9 & 205.9 & 326.1 & 43 & 229.1 & 218.3 & 10.8 & 3.23 & 223.6 & 0.49 \\
\hline MCB 4 & 3686194.0 & 431249.9 & 229.6 & 208.6 & 348.2 & 39 & 228.0 & 210.9 & 17.1 & 3.79 & 2228 & 0.61 \\
\hline MCB 5 & 3686174.0 & 431324.3 & 226.3 & 206.3 & 337.7 & 43 & 229.0 & 220.0 & 9.0 & 2.61 & 224.7 & 0.40 \\
\hline$M C B 6$ & 3686259.0 & 431394.4 & 219.7 & 199.7 & 329.9 & 45 & 2244 & 2133 & 111 & 3.36 & 2179 & 0.50 \\
\hline MCB 8D & 3686119.0 & 431329.0 & 225.7 & 205.7 & 337.4 & 15 & 229.2 & 218.7 & 10.5 & 2.33 & .225 .3 & 0.60 \\
\hline MCB 9D & 3686239.8 & 431274.6 & 226.2 & 206.2 & 339.1 & 15 & 226.5 & 221.4 & 5.1 & .1 .48 & 223.9 & 0.38 \\
\hline MCB $10 \mathrm{D}$ & 3686605.3 & 431417.2 & 244.9 & 224.9 & 317.9 & 3 & 239.1 & 237.7 & 1.4 & 0.73 & 238.5 & 0.42 \\
\hline MCB 11D & 3686031.8 & 431620.6 & 230.3 & 210.3 & 300.3 & 14 & 221.2 & 215.3 & 5.9 & 2.02 & 218.5 & 0.54 \\
\hline MCB 13D & 3685773.0 & 431275.2 & 235.0 & 214.9 & 355.0 & 7 & 225.4 & 224.5 & 0.9 & 0.38 & 2249 & 0.14 \\
\hline MGA 36 & 3682737.8 & 438735.7 & .254 .2 & 234.2 & 296.2 & 5 & 238.8 & 236.3 & 25 & 0.89 & 237.4 & 0.40 \\
\hline$M G C$ & 36826905 & 437910.5 & 237.3 & 217.3 & 282.3 & 21 & 232.6 & 226.1 & 6.5 & 1.57 & 2296 & 0.34 \\
\hline MGC 11 & 3682689.8 & 437971.4 & 239.2 & 219.2 & 289.2 & 2 & 231.7 & 229.7 & 2.0 & 1.41 & 230.7 & 1.00 \\
\hline MGC 19 & 3682685.3 & 438215.1 & 234.6 & 230.6 & 284.6 & 20 & 236.6 & 230.1 & .6 .5 & 1.52 & 232.4 & 0.34 \\
\hline $\mathrm{MGC} 23$ & 3682682.8 & 438336.8 & 247.9 & 227.9 & 283.9 & 5 & 245.7 & 231.7 & 14.0 & 5.36 & 237.4 & 2.40 \\
\hline MGC 32 & 3682677.8 & 438612.6 & 252.0 & 232.0 & 287.0 & 19 & 248.0 & 242.3 & 5.7 & 1.51 & 2449 & 0.35 \\
\hline MGC 36 & 3682676.5 & 438736.8 & 254.4 & 234.4 & 294.4 & 18 & 239.6 & 233.6 & 6.0 & 1.57 & 236.0 & 0.37 \\
\hline MGE 9 & 3682630.0 & 437908.8 & 238.1 & 218.1 & 2811 & 13 & 231.1 & 2276 & 3.5 & 0.88 & 229.1 & 0.24 \\
\hline$M G E 21$ & 3682622.5 & 438274.9 & 247.9 & 227.9 & 282.9 & 10 & 236.0 & 230.0 & 6.0 & 1.78 & 234.1 & 0.56 \\
\hline MGE 30 & 3682617.3 & 438553.6 & 249.3 & 229.3 & 280.3 & 17 & 240.2 & 2338 & 64 & 175 & 2364 & 0.42 \\
\hline MGG 15 & 3682567.8 & 438090.6 & 243.3 & 223.3 & 282.3 & 6 & 238.5 & 230.0 & 8.5 & 3.03 & 232.9 & 1.24 \\
\hline MGG 19 & 3682565.8 & 438213.7 & 246.0 & 226.0 & 278.0 & 10 & 2350 & 226.0 & 9.0 & 2.68 & 232.5 & 0.85 \\
\hline MGG 23 & $\begin{array}{r}3682563.3 \\
\hdashline\end{array}$ & 438335.3 & 247.1 & 227.1 & 276.1 & 10 & 237.6 & 233.8 & 3.8 & .1 .35 & .235 .2 & 0.43 \\
\hline MGG 28. & 3682559.5 & 438490.1 & 250.3 & 230.3 & 274.3 & 5 & 236.9 & 2340 & 2.9 & 1.14 & 235.6 & 0.51 \\
\hline MGG 36 & 36825543 & 438737.6 & 252.5 & 232.5 & 290.5 & 13 & 241.2 & 234.8 & 64 & 1.86 & 237.7 & 0.52 \\
\hline$M S B$ IA & 3687928.3 & 431405.4 & 253.2 & 223.2 & 352.2 & 6 & 232.3 & 227.9 & 4.4 & 1.74 & 231.5 & 0.71 \\
\hline MSB 10 & 3687925.5 & 431401.8 & 229.8 & 210.4 & 352.8 & 42 & 232.1 & 227.5 & 4.6 & 1.17 & 230.5 & 0.18 \\
\hline MSB $2 A$ & 3688026.3 & 431439.3 & 252.6 & 222.6 & 351.2 & 8 & 233.8 & 228.8 & 5.0 & 1.59 & 232.6 & 0.56 \\
\hline MSB 2D & 3688024.5 & 431444.1 & 230.1 & 210.7 & 351.7 & 41 & 233.2 & 228.3 & 4.9 & 1.25 & .231.2. & 0.20 \\
\hline MSB $3 D$ & 3688026.0 & 431355.9 & 230.7 & 211.2 & 358.7 & 27 & 231.5 & 221.0 & 10.5 & 2.11 & 230.0 & 0.41 \\
\hline MSB 4A & 3687925.3 & 431349.5 & 254.8 & 224.8 & 352.9 & 7 & 231.6 & 231.2 & 0.4 & 0.18 & 231.4 & 0.07 \\
\hline MSB 4D & 3687943.3 & 431335.9 & 228.4 & 2090 & 3534 & 41 & 231.8 & 226.3 & 5.4 & 1.26 & 229.7 & 0.20 \\
\hline MSB $5 A$ & 3687699.0 & 431018.9 & 247.2 & 217.2 & 342.2 & 27 & 229.0 & 225.6 & 3.4 & 0.93 & 2279 & 0.18 \\
\hline$M S B 6 A$ & 3687370.8 & 431001.9 & 2419 & 2119 & 341.9 & 54 & 229.1 & 2224 & 6.7 & 1.83 & 226.5 & 0.25 \\
\hline MSB 7A & 3687308.8 & 431200.3 & 242.0 & 212.0 & 342.0 & 54 & 230.5 & 220.5 & 10.0 & .1 .74 & 227.8 & 0.24 \\
\hline MSB 8A & 3687467.0 & 431298.8 & 242.4 & 2124 & 342.4 & 39 & 230.9 & 227.3 & 3.7 & 1.02 & 229.5 & 0.16 \\
\hline$M S B$ & 36879950 & 431283.7 & 241.6 & 221.6 & 357.6 & 30 & 233.0 & 2286 & 4.4 & 0.98 & 231.3 & 0.18 \\
\hline MSB 11E & 3688156.8 & 431281.6 & 251.0 & 231.0 & 363.5 & 17 & 241.1 & 239.4 & 1.7 & 0.57 & 240.0 & 0.14 \\
\hline MSB 11F & 3688144.0 & 431289.8 & 243.1 & 223.1 & 363.6 & 24 & 233.1 & 229.8 & 3.2 & 0.72 & 231.4 & 0.15 \\
\hline MSB $12 D$ & 3687795.8 & 431001.5 & 245.3 & 225.3 & 347.3 & 6 & 234.4 & 234.2 & 0.2 & 0 & 234.3 & 0.00 \\
\hline
\end{tabular}




\begin{tabular}{|c|c|c|c|c|c|c|c|c|c|c|c|c|}
\hline Well ID & UTMN & UTME & Sz top & Sz bot. & Gr. Elev. & No. & Max. & Min. & Range & Std. Dev. & Mean WL & StdErr_Mean \\
\hline MSB 13C & 3687737.3 & 431188.3 & 244.1 & 224.1 & 345.1 & 17 & 230.3 & 227.3 & 3.0 & 0.93 & 228.9 & 0.23 \\
\hline$M S B$ 13D & 3687744.3 & 431181.4 & 231.5 & 211.5 & 345.5 & 45 & 229.7 & 224.7 & 5.0 & 1.14 & 228.2 & 0.17 \\
\hline$M S B$ 14C & 36878918 & 431450.9 & 243.9 & 223.9 & 347.2 & 22 & 235.0 & 232.1 & 2.9 & 0.94 & 232.8 & 0.20 \\
\hline MSB $15 C$ & 3688282.0 & 431286.2 & 260.6 & 240.6 & 364.8 & 39 & 248.9 & 2427 & 6.2 & 1.4 & 244.1 & 0.22 \\
\hline MSB $15 D$ & 36882733 & 431290.2 & 241.4 & 221.9 & 366.4 & 45 & 235.7 & 227.5 & 8.2 & 1.35 & 232.7 & 0.20 \\
\hline MSB $16 \mathrm{C}$ & 36884818 & 431192.2 & 244.8 & 224.8 & 365.8 & 33 & 232.5 & 228.8 & 3.7 & 0.84 & 230.9 & 0.15 \\
\hline$M S B 170$ & 3687581.5 & 430813.3 & 232.8 & 213.3 & 357.8 & 39 & 228.6 & 224.1 & 4.5 & 1.14 & 227.0 & 0.18 \\
\hline$M S B$ 18C & 3687162.0 & 431079.1 & 229.2 & 209.2 & 340.4 & 40 & 232.9 & 223.5 & 9.4 & 2.56 & 228.1 & 0.40 \\
\hline$M S B 20 \mathrm{C}$ & 3687926.3 & 430510.6 & 2327 & 212.7 & 3527 & 40 & 229.3 & 225.6 & 37 & 0.83 & 227.6 & 0.13 \\
\hline MSB 21C & 3688234.3 & 430718.1 & 233.2 & 213.2 & 353.0 & 45 & 231.6 & 2271 & 4.5 & 0.99 & 229.5 & 0.15 \\
\hline MSB 22 & 3688022.8 & 431352.4 & 243.2 & 223.2 & 3582 & 10 & 2324 & 230.5 & 2.0 & 0.85 & 231.6 & 0.27 \\
\hline$M S B 24$ & 3688860.0 & 431245.7 & 243.9 & 223.9 & 378.9 & 45 & 255.5 & 233.8 & 217 & 3.07 & 236.1 & 0.46 \\
\hline$M S B 25$ & 3688554.0 & 4314028 & 2447 & 224.7 & 364.7 & 5 & 237.5 & 237.2 & 0.3 & 0.13 & 2374 & 0.06 \\
\hline$M S B 26$ & 3688698.0 & 431023.9 & 240.7 & 2207 & 359.7 & 20 & 237.9 & 233.6 & 4.3 & 0.94 & 237.3 & 0.21 \\
\hline$M S B 27$ & 3688884.8 & 431093.9 & 244.0 & 2340 & 374.0 & 43 & 240.9 & 235.7 & 5.2 & 126 & 237.7 & 0.19 \\
\hline MSB 28 & 3688703.0 & 430860.4 & 230.6 & 210.6 & 352.6 & 44 & 2324 & 228.3 & 4.2 & 111 & 230.5 & 0.17 \\
\hline MSB $29 D D$ & 3689766.3 & 431094.2 & 250.4 & 230.4 & 362.4 & 14 & 233.9 & 232.0 & 1.9 & 0.55 & 233.2 & 0.15 \\
\hline MSB $30 \mathrm{C}$ & 3688807.3 & 430594.8 & 237.6 & 217.6 & 352.6 & 44 & 2329 & 229.0 & 3.9 & 0.98 & 230.8 & 0.15 \\
\hline$M S B 31 C$ & 3688255.3 & 4317790 & 236.1 & 216.1 & 346.1 & 45 & 2367 & 231.3 & 5.3 & 1.11 & 234.6 & 0.17 \\
\hline MSB 33 & 3687577.8 & 432892.7 & 228.7 & 2087 & 253.7 & 42 & 2224 & 216.4 & 6.0 & 1.02 & 218.1 & 0.16 \\
\hline MSB 340 & 3689063.0 & 431358.9 & 240.9 & 220.9 & 381.9 & 35 & 234.6 & 228.2 & 6.4 & 1.44 & 230.8 & 0.24 \\
\hline MSB 350 & 3688444.8 & 431965.2 & 254.5 & 233.8 & 349.5 & 11 & 243.7 & 243.4 & 0.3 & 0.13 & 2436 & 0.04 \\
\hline MSB 360 & 36877990 & 431907.0 & 249.5 & 228.8 & 339.5 & 32 & 238.2 & 228.9 & 9.3 & 251 & 236.7 & 0.44 \\
\hline MSB 370 & 3689308.3 & 431521.4 & 245.7 & 225.1 & 380.7 & 27 & 233.1 & 228.8 & 4.3 & 1.11 & 231.7 & 0.21 \\
\hline MSB 380 & 3688299.3 & 431629.3 & 240.4 & 220.9 & 356.4 & 25 & 237.4 & 232.8 & 4.6 & 0.93 & 234.1 & 0.19 \\
\hline MSB & 3687675.5 & 431562.7 & 239.7 & 219.0 & 339.7 & 47 & 234.0 & 229.2 & 4.9 & 1.28 & 231.8 & 0.19 \\
\hline$M S B 40 D$ & 3686879.8 & 432100.2 & 236.8 & 216.2 & 320.8 & 25 & 238.1 & 225.9 & 12.2 & 2.28 & 228.8 & 0.46 \\
\hline MSB 410 & 3688907.3 & 432553.4 & 247.8 & 227.1 & 322.8 & 18 & 241.2 & 237.2 & 3.9 & 0.9 & 240.9 & 0.21 \\
\hline$M S B 42 D$ & 3689167.3 & 431677.7 & 247.2 & 2266 & 3742 & 27 & 2353 & 231.2 & 4.2 & 0.97 & 233.5 & 0.19 \\
\hline MSB $430 D$ & 3689425.0 & 430645.3 & 243.2 & 223.1 & 356.2 & 15 & 233.2 & 230.0 & 3.1 & 0.93 & 231.9 & 0.24 \\
\hline MSB $44 C$ & 3688762.0 & 431793.3 & 239.4 & 229.4 & 374.4 & 38 & 240.5 & 231.4 & 9.1 & 2.1 & 234.9 & 0.34 \\
\hline$M S B \quad 46 C$ & 3688613.3 & 431691.4 & 247.0 & 237.0 & 370.0 & 29 & 241.3 & 236.2 & 5.1 & 1.51 & 239.7 & 0.28 \\
\hline MSBB 470 & 3689857.8 & 4314018 & 246.1 & 226.5 & 366.6 & 43 & 235.4 & 230.9 & 4.4 & 1.05 & 233.8 & 0.16 \\
\hline MSB ABD & 3690428.8 & 4316919 & 243.5 & 2220 & 360.5 & 37 & 249.0 & 230.1 & 19.0 & 6.16 & 235.4 & 1.01 \\
\hline MSB 490 & 3686940.8 & 431140.4 & 236.4 & 2167 & 331.8 & 43 & 232.4 & 2246 & 7.8 & 2.3 & 2287 & 0.35 \\
\hline MSB $50 D$ & 3687056.0 & 433011.6 & 210.9 & 190.8 & 2207 & 38 & 211.3 & 2009 & 10.4 & 1.61 & 2028 & 026 \\
\hline$M S B 51 D$ & 3685213 & 433340.8 & 218.5 & 198.8 & 2600 & 39 & 2122 & 208.1 & 4.0 & 1.07 & 210.1 & 0.17 \\
\hline MSB 520 & 3689118.8 & 432404.4 & 250.8 & 231.1 & 319.4 & 37 & 240.0 & 233.9 & 6.2 & 1.54 & 237.9 & 0.25 \\
\hline MSB 530 & 3690156.5 & 4320772 & 244.9 & 2236 & 3429 & 39 & 235.1 & 226.7 & 8.4 & 1.44 & 233.2 & 0.23 \\
\hline MSB 540 & 3690371.3 & 4313297 & 244.8 & 223.8 & 3714 & 40 & 236.5 & 2319 & 4.6 & 105 & 234.2 & 0.17 \\
\hline MSBB 55D & 3690183.3 & 431107.8 & 245.9 & 224.7 & 365.9 & 33 & 237.1 & 232.8 & 4.3 & 1.11 & 234.5 & 0.19 \\
\hline MSB 560 & 3688797.8 & 429167.2 & 232.4 & 2111 & 277.4 & 43 & 2229 & 218.7 & 4.2 & 0.86 & 220.8 & 0.13 \\
\hline M̈SB 570 & 36879693 & 43146399 & 2296 & 210.1 & 3541 & 37 & 233.3 & 228.6 & 4.7 & 121 & 2315 & 0.20 \\
\hline$M S B 58 D$ & 368059.3 & 4313953 & 230.5 & 211.1 & 355.8 & 41 & 233.0 & 226.2 & 6.7 & 1.38 & 231.2 & 0.22 \\
\hline MSB $59 D$ & 3687987.0 & 4313053 & 229.3 & 209.9 & 357.3 & 38 & 231.8 & 226.5 & 5.3 & 1.38 & 230.0 & 0.22 \\
\hline MSB & 3687903.5 & 431370.5 & 228.3 & 208.9 & 352.3 & 39 & 232.1 & 227.3 & 4.8 & 1.2 & 230.3 & 0.19 \\
\hline MSB 610 & 3690219.5 & 432346.9 & 234.2 & 214.3 & 315.7 & 39 & 227.8 & 222.4 & 5.3 & 1.54 & 225.1 & 0.25 \\
\hline MSB 620 & 3687827.3 & 431258.7 & 231.9 & 2124 & 347.4 & 42 & 230.7 & 226.1 & 4.7 & 1.2 & 229.2 & 0.19 \\
\hline MSB 630 & 3687650.8 & 431370.1 & 232.8 & 212.8 & 344.8 & 42 & 231.1 & 2260 & 5.1 & 1.24 & 229.6 & 0.19 \\
\hline MSB 640 & 3687598.5 & 430941.3 & 230.1 & 210.1 & 346.6 & 39 & 228.7 & 223.3 & 5.4 & 1.27 & 226.9 & 0.20 \\
\hline MSB 65D & 3688118.3 & 431623.9 & 243.9 & 224.4 & 347.1 & 45 & 236.5 & 231.3 & 5.2 & 116 & 233.9 & 0.17 \\
\hline MिS66D & 3689377.8 & 431321.4 & 239.5 & 2200 & 381.5 & 28 & 234.4 & 224.8 & 96 & 1.7 & 231.9 & 0.32 \\
\hline MSB67D & 3689787.8 & 431372.6 & 2410 & 221.5 & 363.1 & 42 & 235.3 & 2316 & 3.8 & 0.81 & 233.8 & 0.12 \\
\hline$M S B 60$ & 3689823.5 & 431468.0 & 239.9 & 220.4 & 3549 & 38 & 2359 & 2321 & 3.8 & 0.83 & 234.3 & 0.13 \\
\hline MSB 690 & 3690110.8 & 431322.4 & 239.8 & 220.3 & 379.8 & 44 & 236.9 & 231.7 & 5.2 & 1.05 & 233.8 & 0.16 \\
\hline MSB70D & 3687293.3 & 430559.9 & 228.3 & 208.2 & 360.3 & 36 & 2233 & 217.3 & 6.0 & 1.48 & 221.3 & 0.25 \\
\hline MSB74D & 3687635.0 & 432373.7 & 237.1 & 217.1 & 313.1 & 38 & 2370 & 230.7 & 6.3 & 1.29 & 2329 & 0.21 \\
\hline MSBT7D & 3690257.5 & 4318832 & 236.2 & 216.2 & 355.2 & 31 & 236.1 & 231.1 & 5.0 & 1.39 & 234.2 & 0.25 \\
\hline MSB 78 & 36878390 & 430345.4 & 225.5 & 206.1 & 361.1 & 18 & 225.9 & 219.2 & 67 & 2.04 & 224.1 & 0.48 \\
\hline MSB 78DR & 3687839.0 & 430341.1 & 226.9 & 206.9 & 361.5 & 8 & 224.5 & 2220 & 2.6 & 0.93 & 223.1 & 0.33 \\
\hline MSB 82D & 3689950.5 & 431240.3 & 236.9 & 216.8 & 3714 & 35 & 234.8 & 2307 & 4.1 & 0.94 & 233.5 & 0.16 \\
\hline MSB 830 & 3690254.3 & 4311913 & 236.1 & 216.7 & 3693 & 36 & 234.9 & 230.5 & 4.4 & 1.02 & 2337 & 0.17 \\
\hline MSB 85D & 3690236.3 & 431474.9 & 236.3 & 216.2 & 378.8 & 36 & 234.8 & 230.5 & 4.3 & 0.96 & 233.5 & 0.16 \\
\hline MSB 87C & 3688352.3 & 432276.1 & 246.6 & 2416 & 334.6 & 18 & 244.4 & 241.7 & 2.8 & 0.66 & 243.8 & 0.16 \\
\hline MSBBo & 3687157.8 & 432843.1 & 212.2 & 1921 & 234.9 & 15 & 205.9 & 204.0 & 119 & 0.55 & 205.1 & 0.14 \\
\hline MWD 10 & 3684764.8 & 443749.1 & 272.9 & 227.8 & 3279 & 7 & 272.4 & 264.2 & 8.3 & 271 & 268.0 & 1.02 \\
\hline MWD $2 D$ & 3684833.3 & 443758.9 & 267.5 & 247.5 & 3225 & 7 & 2719 & 265.3 & 6.6 & 217 & 269.0 & 0.82 \\
\hline MMWD SD & 3684739.3 & 443910.2 & 269.5 & 249.5 & 323.0 & 7 & 271.0 & 264.8 & 6.1 & 2.03 & 268.2 & 0.77 \\
\hline
\end{tabular}




\begin{tabular}{|c|c|c|c|c|c|c|c|c|c|c|c|c|}
\hline Well ID & UTMN & UTME & Sz top & Szbot. & Gr. Elev. & No. & Max. & Min. & Range & Std. Dev. & Mean WL & StdEr_Mean \\
\hline MWD 8 & 3684880.5 & 443662.2 & 273.7 & 253.7 & 323.7 & 7 & 272.4 & 266.3 & 6.0 & 2.02 & 269.7 & 0.76 \\
\hline NBG 1 & 3683347.8 & 436779.6 & 232.3 & 200.9 & 309.5 & 31 & 226.6 & 223.1 & 3.5 & 1.08 & 224.5 & 0.19 \\
\hline $\mathrm{NBG} 2$ & 3683312.5 & 436835.0 & 233.6 & 203.6 & 310.6 & 30 & 227.1 & 223.5 & 3.6 & 1.12 & 2250 & 0.20 \\
\hline NBG 3 & 3683292.8 & 436890.8 & 233.5 & 202.1 & 310.5 & 29 & 220.7 & 215.0 & 5.7 & 1.97 & 217.5 & 0.37 \\
\hline NBG 4 & 3683340.3 & 436954.6 & 227.5 & 196.1 & 304.5 & 30 & 220.3 & 214.6 & 5.7 & 1.88 & 217.2 & 0.34 \\
\hline NBG 5 & 3683374.0 & 437000.3 & 226.4 & 194.9 & 3014 & 30 & 221.5 & 214.9 & 6.6 & 213 & 217.9 & 0.39 \\
\hline NPM $4 D D$ & 3679412.0 & 440903.2 & 306.4 & 296.4 & 311.3 & 9 & 310.3 & 297.6 & 12.7 & 4.57 & 306.0 & 1.52 \\
\hline NPM $19 A$ & 3679983.5 & 4406127 & 268.2 & 248.2 & 327.0 & 10 & 273.9 & 266.8 & 7.1 & 2.23 & 270.6 & 0.71 \\
\hline NPM $34 A$ & 3679218.3 & 440698.4 & 289.8 & 279.8 & 320.3 & 10 & 293.5 & 286.3 & 7.2 & 2.11 & 290.6 & 0.67 \\
\hline $\mathrm{P} 19 \mathrm{D}$ & 3678542.0 & 442603.1 & 273.2 & 253.2 & 297.7 & 1 & 267.1 & 267.1 & 0.0 & - & 267.1 & \\
\hline $\mathrm{P} 26 \mathrm{D}$ & 3675114.8 & 429265.5 & 121.9 & 101.8 & 151.8 & 36 & 123.2 & 112.7 & 10.5 & 274 & 118.0 & 0.46 \\
\hline P 290 & 3683131.0 & 432756.8 & 173.9 & 153.9 & 266.4 & 3 & 170.0 & 167.7 & 2.3 & 1.23 & 169.1 & 0.71 \\
\hline PAC 1 & 3676847.8 & 446363.4 & 283.9 & 253.9 & 293.9 & 28 & 287.5 & 282.3 & 5.2 & 1.29 & 284.9 & 0.24 \\
\hline PAC 2 & 3676884.8 & 446422.3 & 277.9 & 247.9 & 282.9 & 27 & 274.1 & 268.2 & 5.9 & 1.72 & 271.1 & 0.33 \\
\hline PAC 3 & 3676877.5 & 446382.4 & 282.9 & 252.9 & 287.9 & 28 & 277.4 & 268.4 & 9.0 & 2.28 & 271.4 & .0 .43 \\
\hline PAC 4 & 3676855.5 & 446399.1 & 280.6 & 250.6 & 289.6 & 27 & 286.1 & 282.5 & 3.6 & 0.92 & 284.5 & 0.18 \\
\hline PAC 5 & 3676879.8 & 4463980 & 275.1 & 255.1 & 2871 & 28 & 280.0 & 269.3 & 10.7 & 2.39 & 275.2 & 0.45 \\
\hline$P A C 6$ & 36768823 & 446391.6 & 275.2 & 255.2 & 287.2 & 27 & 278.0 & 270.6 & 7.5 & 1.93 & 274.7 & 0.37 \\
\hline PCB $1 A$ & 3676162.8 & 446227.8 & 293.5 & 263.5 & 303.5 & 24 & 286.2 & 276.0 & 10.2 & 2.72 & 280.4 & 0.56 \\
\hline PCB 2A & 3676089.8 & 446213.5 & 287.8 & 257.8 & 302.8 & 24 & 285.3 & 274.7 & 10.5 & 2.75 & 279.3 & 0.56 \\
\hline PCB $3 A$ & 3676109.3 & 446129.4 & 292.7 & 262.7 & 302.7 & 27 & 291.3 & 277.5 & 13.8 & 2.97 & 281.6 & 0.57 \\
\hline PCB $4 A$ & 3676177.5 & 446153.3 & 292.9 & 262.9 & 307.9 & 25 & 284.7 & 274.9 & 9.9 & 2.68 & 279.5 & 0.54 \\
\hline PDB 4 & 3676444.0 & 445854.6 & 286.2 & 266.2 & 317.1 & 9 & 281.7 & 278.1 & 3.6 & 1.37 & 279.3 & 0.46 \\
\hline PDB 5 & 3676597.5 & 445728.1 & 284.2 & 264.2 & 317.2 & 10 & 279.8 & 276.4 & 3.3 & 1.24 & 277.9 & 0.39 \\
\hline PRP IA & 3676625.5 & 445122.9 & 262.9 & 232.9 & 2829 & 26 & 255.1 & 2446 & 10.5 & 2.41 & 249.3 & 0.47 \\
\hline PAP 2 & 3676670.5 & 445164.1 & 264.1 & 234.1 & 284.1 & 26 & 269.5 & 2506 & 19.0 & 5.03 & 256.0 & 0.99 \\
\hline PRP 3 & 3676612.5 & 445182.3 & 258.6 & 228.6 & 278.6 & 25 & 264.2 & 250.5 & 13.7 & 3.67 & 255.8 & 0.73 \\
\hline PRP 4 & 3676661.8 & 445214.5 & 262.9 & 232.9 & 282.9 & 27 & 264.9 & 254.2 & 10.7 & 2.69 & 257.9 & 0.52 \\
\hline PSB 1A & 3676398.0 & 445706.3 & 287.4 & 257.4 & 327.4 & 34 & 280.9 & 272.2 & 8.6 & 2.82 & 276.5 & 0.48 \\
\hline PSB $2 A$ & 3676356.0 & 445652.2 & 287.2 & .257 .2 & 3222 & 34 & 281.6 & 271.6 & 10.0 & 2.92 & 276.5 & 0.50 \\
\hline PSB $3 A$ & $\begin{array}{r}3676294.5 \\
\end{array}$ & 445574.1 & 286.5 & 256.5 & 316.5 & 34 & 280.1 & 2701 & 10.0 & 3.06 & 275.3 & 0.52 \\
\hline PSB 4A & 3676234.5 & 445525.9 & 285.5 & 255.5 & 310.5 & 34 & 279.3 & .268.8 & 10.5 & 3.37 & 274.5 & 0.58 \\
\hline PSB $5 A$ & 36762580 & 445606.6 & 2923 & 262.3 & 317.3 & 35 & 280.7 & 270.5 & 10.3 & 3.23 & 275.8 & 0.55 \\
\hline PSB $6 A$ & 3676323.3 & 445698.4 & 292.1 & 262.1 & 322.1 & 33 & 281.5 & 272.5 & 9.0 & 2.98 & 277.3 & 0.52 \\
\hline PSB 7A & 3676410.5 & 445757.5 & 289.0 & 259.0 & 329.0 & 34 & 280.8 & 272.6 & 8.2 & 2.69 & 277.0 & 0.46 \\
\hline PSS 1D & 3676927.0 & 449705.3 & 202.1 & 182.1 & 217.5 & 26 & 206.4 & 192.3 & 14.2 & .3 .9 & $\begin{array}{r}198.2 \\
\end{array}$ & 0.76 \\
\hline PSS 2D & 3676641.0 & 449965.1 & 197.1 & 177.1 & 226.6 & 26 & 204.2 & 190.6 & 13.6 & 3.64 & 195.3 & 0.71 \\
\hline PSS 3D & 3676666.3 & 450032.9 & 198.5 & 178.5 & 231.8 & 12 & 204.2 & 194.9 & 9.3 & 3.12 & 198.0 & 0.90 \\
\hline RAC 1 & 3681098.3 & 446215.4 & 277.3 & 247.3 & 282.3 & 23 & 276.3 & 269.3 & 6.9 & 1.92 & 274.2 & 0.40 \\
\hline$R A C 2$ & 3681075.8 & 446226.2 & 273.4 & 243.4 & 278.4 & 22 & 273.8 & 268.9 & 4.9 & 1.32 & 272.8 & 0.28 \\
\hline$R A C 3$ & 36810930 & 446255.8 & 272.3 & 242.3 & 277.3 & 23 & 274.1 & 268.0 & 6.1 & 1.54 & 272.6 & 0.32 \\
\hline RAC 4 & 3681071.3 & 446242.0 & 268.2 & 238.2 & 277.2 & 23 & 273.7 & 267.8 & 5.8 & 1.65 & 271.9 & 0.34 \\
\hline RBW $1 D$ & 3682744.5 & 444891.6 & 263.1 & 243.0 & 284.1 & 3 & 259.5 & 258.1 & 1.4 & 0.78 & 259.0 & 0.45 \\
\hline RBW $2 D$ & 3681487.3 & 444879.3 & 304.9 & 284.9 & 324.9 & 3 & 298.5 & 296.1 & 2.4 & 1.25 & 297.6 & 0.72 \\
\hline RCP $1 D$ & $\begin{array}{r}3681494.5 \\
-\end{array}$ & 445796.2 & 281.3 & 261.3 & 294.8 & 12 & 285.0 & 277.8 & 7.3 & 2.2 & 281.8 & .0 .64 \\
\hline RDB $1 D$ & 3681637.8 & 445926.0 & 285.5 & 265.5 & 290.5 & 25 & 288.5 & 2827 & 5.8 & 1.29 & 286.1 & 0.26 \\
\hline RDB 20 & 3681573.0 & 445949.7 & 2857 & 265.7 & 2907 & 24 & 287.6 & 282.4 & 5.2 & 1.1 & 285.2 & 0.22 \\
\hline RDB 3D & $\begin{array}{r}3681594.5 \\
.\end{array}$ & 445978.1 & 285.8 & ..265.8 & 2908 & 25 & 2859 & 2794 & 6.5 & 1.6 & 283.1 & 0.32 \\
\hline RRP 1 & 3681155.3 & 446575.0 & 272.4 & 242.4 & 282.4 & 23 & 273.5 & 260.8 & 127 & 3.31 & 266.2 & 0.69 \\
\hline RRP 2 & 3681166.8 & 446640.2 & .272 .5 & 242.5 & 282.5 & 22 & 270.8 & 259.7 & 11.1 & 3.35 & 265.0 & 0.71 \\
\hline RRP 3 & 3681130.3 & 446675.5 & 268.1 & 238.1 & 278.1 & 24 & 270.6 & 258.7 & 12.0 & 3.73 & 265.2 & 0.76 \\
\hline RRP 4 & 3681104.8 & 446645.1 & 268.3 & 238.3 & 278.3 & 23 & 271.4 & 258.8 & 12.6 & 3.42 & 264.5 & 0.71 \\
\hline RSA 7 & 3681939.3 & 445838.9 & 289.5 & 269.6 & 310.5 & 21 & 300.4 & 275.2 & 25.2 & 7.92 & 289.8 & 1.73 \\
\hline RSA 8 & 3681977.0 & 445889.3 & 285.5 & 265.6 & 310.2 & 21 & 297.3 & 272.3 & 25.0 & 7.59 & 286.7 & 1.66 \\
\hline RSA 9 & 3682029.0 & 445932.0 & 284.5 & 264.6 & 309.7 & 24 & 296.7 & 273.2 & 23.5 & 7.17 & 283.9 & 1.46 \\
\hline RSA 10 & 3682000.3 & 445867.3 & 288.7 & 268.8 & 309.7 & 21 & 292.3 & 272.8 & 19.5 & 5.14 & 282.0 & 1.12 \\
\hline RSB 7 & 3681820.3 & 445868.4 & 292.6 & 272.7 & 307.2 & 23 & 293.5 & 279.3 & 14.2 & 4.24 & 286.4 & 0.88 \\
\hline RSB 8 & 3681824.5 & 445915.8 & .294.3. & 274.3 & 304.3 & 19 & 295.8 & 281.0 & 14.8 & 4.22 & 288.6. & 0.97 \\
\hline RSC 2 & 3681910.3 & 445552.0 & 281.9 & 261.9 & 299.9 & 18 & 284.6 & 273.0 & 11.6 & 3.42 & 279.0 & 0.81 \\
\hline RSC 3 & 3682012.8 & 445598.5 & 278.6 & 258.6 & 299.6 & 18 & 283.3 & 270.0 & 13.3 & 3.88 & 277.8 & 0.91 \\
\hline RSC 4 & 3682127.3 & 445665.1 & 288.6 & 268.6 & 298.6 & 20 & 291.3 & 273.1 & 18.2 & 5.99 & 281.3 & 1.34 \\
\hline RSC 5 & 3682197.0 & 445760.3 & 278.3 & 258.3 & 302.3 & 21 & 284.4 & 266.2 & 18.2 & 5.14 & 274.5 & 1.12 \\
\hline RSC 6 & 3682160.5 & 445862.6 & 287.7 & 267.7 & 300.7 & 21 & 296.1 & 273.9 & 22.2 & 7.76 & 286.4 & 1.69 \\
\hline RSC 7 & 3682060.3 & 445935.6 & 283.4 & 263.4 & 306.4 & 19 & 293.1 & 267.8 & 25.3 & 7.51 & 283.4 & 1.72 \\
\hline RSC 8 & 3681965.8 & 446003.5 & 299.3 & 271.3 & 307.3 & 22 & 303.2 & 283.8 & 19.4 & 6.65 & 293.5 & 1.42 \\
\hline RSC 9 & 3682115.8 & 445472.8 & 271.6 & 251.6 & 299.6 & 17 & 279.3 & 263.6 & 15.7 & 3.87 & .272.3 & 0.94 \\
\hline RSC 10 & 3682352.3 & 445641.6 & 275.5 & 255.5 & 293.5 & 18 & 277.9 & 262.4 & 15.5 & 4.06 & 272.3 & 0.96 \\
\hline RSD 1 & 3681756.5 & 445911.3 & 287.7 & 267.9 & 298.7 & 27 & 291.4 & 280.5 & 10.9 & 3.15 & 286.7 & 0.61 \\
\hline
\end{tabular}




\begin{tabular}{|c|c|c|c|c|c|c|c|c|c|c|c|c|}
\hline Well ID & UTMN & UTME & Sz top & Sz bot. & Gr. Elev. & No. & Max. & Min. & Range & Std. Dev. & Mean WL & StdEr_Mean \\
\hline ASD 3 & 3681699.5 & 445827.4 & 289.1 & 269.3 & 298.9 & 27 & 292.1 & 277.3 & 14.8 & 3.5 & 287.5 & 0.67 \\
\hline ASD 4 & 3681778.0 & 445940.7 & 290.6 & 270.6 & 299.6 & 23 & 292.0 & 283.6 & 8.4 & 2.56 & 288.6 & 0.53 \\
\hline RSD 5 & 3681787.0 & 445953.9 & 289.6 & 269.6 & 299.6 & 23 & 292.6 & 282.7 & 9.9 & 2.84 & 287.4 & 0.59 \\
\hline RSD 6 & 3681796.3 & 445965.8 & 290.1 & 270.1 & 300.1 & 23 & 291.5 & 282.3 & 9.2 & 2.59 & 287.1 & 0.54 \\
\hline$A S D 7$ & 3681770.8 & 445955.0 & 287.3 & 267.3 & 2913 & 24 & 288.9 & 280.4 & 8.5 & 2.44 & 285.3 & 0.50 \\
\hline ASD 8 & 3681779.8 & 445967.7 & 287.3 & 267.3 & 291.3 & 23 & 289.0 & 281.0 & 8.0 & 2.36 & 285.6 & 0.49 \\
\hline RSE $1 B$ & 3681767.8 & 445776.2 & 295.7 & 275.7 & 3017 & 24 & 296.3 & 278.3 & 18.0 & 4.16 & 290.3 & 0.85 \\
\hline RSE $1 C$ & 3681765.0 & 445772.9 & 288.5 & 268.5 & 301.5 & 24 & 297.7 & 273.3 & 24.4 & 5.75 & 289.6 & 1.17 \\
\hline ASE $3 A$ & 3681739.0 & 445864.8 & 288.0 & 268.2 & 299.2 & 25 & 291.0 & 271.0 & 20.0 & 4.14 & 285.5 & 0.83 \\
\hline RSE 10 & 3681964.5 & 445689.6 & 290.5 & 270.7 & 303.2 & 22 & 2927 & 274.0 & 18.7 & 5.82 & 282.6 & 124 \\
\hline ASE 18 & 3681920.0 & 445718.6 & 288.1 & 268.1 & 305.1 & 22 & 287.1 & 274.1 & 13.0 & 3.9 & 280.1 & 0.83 \\
\hline ASE 19 & 3681929.0 & 445693.9 & 282.5 & 262.5 & 302.5 & 22 & 293.8 & 274.2 & 19.6 & 5.94 & 281.6 & 1.27 \\
\hline ÁSP 10 & 3681509.0 & 445862.2 & 289.7 & 274.7 & 291.8 & 2 & 290.9 & 288.5 & 2.4 & 1.68 & 289.7 & 1.19 \\
\hline ASP 40 & 3681928.3 & 446127.3 & 285.2 & 265.2 & 298.2 & 4 & 280.4 & 279.6 & 0.7 & 0.4 & 280.0 & 0.20 \\
\hline BSP $5 D$ & 3682303.5 & 445982.0 & 283.5 & 263.4 & 294.4 & 4 & 277.4 & 275.2 & 21 & 1.14 & 2762 & 0.57 \\
\hline ASP 60 & 3682276.0 & 445656.8 & 276.0 & 255.9 & 297.9 & 3 & 269.6 & 269.1 & 0.5 & 0.27 & 269.4 & 0.16 \\
\hline$A S P 7 D$ & 3682038.3 & 445427.3 & 278.4 & 258.5 & 302.5 & 3 & 272.0 & 271.4 & 0.6 & 0.28 & 2717 & 0.16 \\
\hline $\mathrm{SBG} 2$ & 3684166.0 & 440352.5 & 235.9 & 205.9 & 287.9 & 24 & 241.1 & 235.2 & 5.9 & 1.84 & 238.0 & 0.38 \\
\hline SBG 3 & 36840100 & 440588.9 & 236.6 & 206.6 & 284.6 & 25 & 240.3 & 230.4 & 9.9 & 2.11 & 237.6 & 0.42 \\
\hline SCA 2 & 3683945.0 & 440421.8 & 245.9 & 215.9 & 286.9 & 19 & 244.3 & 239.6 & 4.8 & 1.58 & 242.2 & 0.36 \\
\hline $\operatorname{ScA} 3$ & 36839493 & 4403713 & 240.3 & 220.3 & 285.3 & 10 & 242.9 & 239.4 & 3.4 & 106 & 2413 & 0.34 \\
\hline$S O A B$ & 3683950.8 & 440370.3 & 277.1 & 267.1 & 285.3 & 16 & 274.6 & 267.3 & 7.3 & 1.94 & 271.1 & 0.49 \\
\hline $\mathrm{SCA} 4$ & 3683922.5 & 440387.9 & 240.4 & 220.4 & 283.9 & 16 & 243.4 & 237.6 & 5.8 & 1.48 & 241.5 & 0.37 \\
\hline SCA $4 A$ & 3683923.0 & 440389.0 & 275.3 & 265.3 & 283.9 & 12 & 270.1 & 265.2 & 4.9 & 1.47 & 268.8 & 0.42 \\
\hline SCA 5 & 3683993.0 & 440362.1 & 243.7 & 223.7 & 2861 & 17 & 2427 & 239.1 & 3.7 & 1.02 & 241.3 & 0.25 \\
\hline SCA 6 & 3683988 & 440433.1 & 241.1 & 221.3 & 283.8 & 16 & 243.5 & 239.8 & 3.8 & 1.03 & 242.0 & 0.26 \\
\hline$S L P 1$ & 368680.8 & 440520.8 & 248.0 & 228.0 & 283.0 & 24 & 248.7 & 242.2 & 6.5 & 1.79 & 245.4 & 0.37 \\
\hline SLW 1 & 3682958.0 & 431945.2 & 180.0 & 160.0 & 3020 & 3 & 7758 & 174.7 & 111 & 0.6 & 175.1 & 0.35 \\
\hline stw 2 & 3683190.8 & 431702.3 & 1970 & 171.9 & 3023 & 3 & 1920 & 1912 & 0.8 & 0.38 & 191.6 & 0.22 \\
\hline SLW 5 & 3682564.3 & 431404.9 & 1946 & 774.6 & 239.6 & 3 & 197.4 & 196.1 & 1.3 & 0.67 & 996.7 & 0.39 \\
\hline SLW 6 & 3682381.5 & 431570.9 & 199.1 & 179.1 & 249.1 & 3 & 203.8 & 2027 & 1.2 & 0.59 & 203.1 & 0.34 \\
\hline SLW 7 & 3682736.3 & 431277.9 & 174.1 & 154.1 & 229.1 & 3 & 176.5 & 175.5 & 1.0 & 0.58 & 175.8 & 0.33 \\
\hline SLW 8 & 3683088.0 & 431262.2 & 195.3 & 165.3 & 255.3 & 3 & 196.9 & 1955 & 14 & 0.78 & 196.0 & 0.45 \\
\hline SRW 1 & 3687141.0 & 429317.6 & 230.2 & 200.2 & 313.2 & 28 & 214.9 & 210.5 & 4.4 & 1.09 & 213.2 & 0.21 \\
\hline SAW 2 & 3687167.0 & 429381.7 & 228.6 & 998.6 & 318.6 & 40 & 217.3 & 211.3 & 6.0 & 1.84 & 2442 & 029 \\
\hline SRW 4 & 3687075.0 & 429443.0 & 230.1 & 2001 & 318.1 & 31 & 215.5 & 2119 & 3.6 & 0.96 & 213.9 & 0.17 \\
\hline$S R$ & 36870228 & 429340.8 & 224.6 & 194.6 & 307.6 & 41 & 217.3 & 2029 & 14.4 & 2.48 & 2113 & 0.39 \\
\hline SiW 6 & 3687068.8 & 429308.7 & 222.6 & 192.6 & 305.6 & 40 & 214.5 & 203.4 & 11.1 & 2.25 & 211.5 & 0.36 \\
\hline SRW 7 & 3686996.8 & 429241.4 & 217.5 & 197.5 & 296.7 & 39 & 213.5 & 207.0 & 6.5 & 1.76 & 210.6 & 028 \\
\hline SRW 8 & 3686894.8 & 429138.3 & 215.7 & 195.7 & 286.7 & 40 & 2116 & 205.6 & 6.0 & 1.62 & 208.7 & 0.26 \\
\hline SRW 9 & 3686705.5 & 428986.9 & 196.3 & 166.3 & 251.3 & 40 & 203.4 & 184.2 & 19.2 & 3.08 & 1990 & 0.49 \\
\hline SRW 10 & 3686962.3 & 429273.4 & 223.0 & 193.0 & 301.0 & 4 & 214.5 & 213.5 & 1.0 & 0.44 & 213.8 & 0.22 \\
\hline SRW 11 & 36870248 & 429201.3 & 220.6 & 190.6 & 293.6 & 39 & 2134 & 2067 & 6.7 & 19 & 210.1 & 0.30 \\
\hline SRW $12 C$ & 3686697.5 & 428741.9 & 1989 & 179.1 & 2343 & 41 & 200.9 & 1917 & 9.3 & 2.19 & 195.8 & 0.34 \\
\hline SAW 13C & 3686816.3 & 429280.9 & 225.4 & 1958 & 295.9 & 41 & 212.4 & 202.1 & 10.3 & 2.21 & 209.2 & 0.35 \\
\hline SAi 140 & 3686931.3 & 4295228 & 228.3 & 1986 & 325.3 & 5 & 217.2 & 217.1 & 0.1 & 0.04 & 217.2 & 0.02 \\
\hline SRW IIC & 36873578 & 429098.8 & 217.3 & 187.7 & 317.3 & 41 & 215.1 & 209.5 & 5.6 & 1.59 & 212.5 & 0.25 \\
\hline SHW $16 \mathrm{C}$ & 3687397.3 & 4296719 & 235.7 & 205.7 & 345.3 & 43 & 217.7 & 2119 & 5.8 & 1.57 & 215.1 & 0.24 \\
\hline TBG 1 & 3674819.3 & 429138.9 & 109.1 & 89.1 & 149.1 & 41 & 102.9 & 98.3 & 46 & 1.25 & 100.7 & 0.20 \\
\hline $\operatorname{TBG} 3$ & 3674800.0 & 429168.4 & 108.9 & 88.9 & 148.9 & 34 & 106.0 & 100.0 & 6.0 & 1.59 & 103.2 & 0.27 \\
\hline TBG 4 & 3674787.0 & 429178.6 & 109.3 & 89.3 & 149.3 & 30 & 104.7 & 100.5 & 4.2 & 1.42 & 103.0 & 0.26 \\
\hline TBG 5 & 3674808.8 & 429229.4 & 112.4 & 924 & 147.4 & 29 & 106.1 & 100.1 & 6.0 & 177 & 1026 & 0.33 \\
\hline TBG 6 & 36748603 & 429167.8 & 109.1 & 89.1 & 145.9 & 31 & 104.6 & 100.0 & 4.6 & 1.29 & 1027 & 0.23 \\
\hline TBG 7 & 3674861.0 & 429264.2 & 104.7 & 84.7 & 1447 & 38 & 109.2 & 102.1 & 7.1 & 2 & 105.6 & 0.32 \\
\hline INX 10 & 3674786.5 & 428998.7 & 99.6 & 79.6 & 154.1 & 34 & 100.9 & 97.8 & 3.1 & 0.71 & 99.6 & 0.12 \\
\hline$T N X 2 D$ & 3674762.8 & 429049.5 & 1028 & 828 & 152.8 & 34 & 100.8 & 97.6 & 3.2 & 0.82 & 99.4 & 0.14 \\
\hline TNX 3D & 3674755.3 & 429150.9 & 104.9 & 84.9 & 151.9 & 35 & 1018 & 97.3 & 4.6 & 1.21 & 99.7 & 0.20 \\
\hline$T N X 4 D$ & 3674730.0 & 429237.2 & 105.5 & 85.5 & 147.5 & 37 & 1062 & 100.1 & 6.1 & 1.61 & 103.2 & 0.26 \\
\hline TNX 50 & 3674753.3 & 429273.2 & 108.5 & 88.5 & 147.0 & 37 & 108.7 & 101.7 & 7.0 & 1.87 & 105.1 & 0.31 \\
\hline$T N X 6 D$ & 3674696.5 & 429339.0 & 109.8 & 89.8 & 148.2 & 37 & 110.2 & 101.7 & 8.4 & 1.98 & 105.4 & 0.33 \\
\hline$T N X 7 D$ & 3674885.5 & 429070.2 & 103.6 & 83.6 & 148.6 & 37 & 102.7 & 98.9 & 3.8 & 0.91 & 1012 & 0.15 \\
\hline$T N \times 8 D$ & 3674439.5 & 429051.0 & 94.0 & 74.0 & 98.0 & 34 & 96.1 & 91.6 & 4.5 & 1.01 & 940 & 0.17 \\
\hline TNX 90 & 3674484.8 & 4290097 & 95.4 & 75.4 & 99.4 & 40 & 96.0 & 92.3 & 3.7 & 0.89 & 93.8 & 0.14 \\
\hline THA 100 & 3674539.8 & 428977.6 & 97.0 & 77.0 & 100.0 & 32 & 96.2 & 92.4 & 3.8 & 0.93 & 94.0 & 0.16 \\
\hline TNX $11 D$ & 3674588.8 & 428941.4 & 93.2 & 73.2 & 97.7 & 35 & 96.4 & 92.7 & 3.7 & 0.92 & 94.1 & 0.16 \\
\hline TiNX $12 D$ & 36746890 & 428872.5 & 93.1 & 73.1 & 97.1 & 34 & 96.5 & 93.6 & 2.9 & 0.64 & 95.0 & 0.11 \\
\hline$T N \times 13 D$ & 3674460.0 & 4289496 & 89.9 & 87.9 & 93.4 & 5 & 92.8 & 91.4 & 13 & 0.55 & 92.0 & 0.25 \\
\hline THN 140 & 3674488.0 & 428941.5 & 87.8 & 85.8 & 92.1 & 4 & 92.3 & 92.0 & 0.3 & 0.16 & 92.1 & 0.08 \\
\hline
\end{tabular}




\begin{tabular}{|c|c|c|c|c|c|c|c|c|c|c|c|c|}
\hline Well ID & UTMN & UTME & Sz top & Szbot. & Gr. Elev. & No. & Max. & Min. & Range & Std. Dev. & Mean WL & StdErr_Mean \\
\hline TNX 15D & 3674515.5 & 428933.1 & 87.9 & 85.9 & 92.5 & 8 & 92.5 & 87.4 & 5.1 & 1.73 & 91.6 & 0.61 \\
\hline$T N \times 16 D$ & 3674539.5 & 428919.4 & 88.1 & 86.1 & 927 & 9 & 927 & 87.6 & 5.0 & 146 & 91.4 & 0.49 \\
\hline TNX 170 & 3674662.3 & 428843.4 & 91.7 & 89.7 & 94.0 & 5 & 93.7 & 92.9 & 0.9 & 0.39 & 93.3 & 0.17 \\
\hline TNX 180 & 3674429.5 & 428956.4 & 86.9 & 84.9 & 91.2 & 4 & 92.1 & 91.4 & 0.8 & 0.31 & 91.7 & 0.16 \\
\hline TNX 190 & 3674390.8 & 428966.0 & 86.9 & 84.9 & 91.2 & 5 & 927 & 89.5 & 32 & 1.21 & 91.5 & 0.54 \\
\hline$T N \times 20 D$ & 3674375.0 & 428969.0 & 88.2 & 862 & 91.4 & 5 & 93.4 & 89.7 & 3.7 & 1.32 & 91.5 & 0.59 \\
\hline$T N \times 210$ & 3674343.8 & 4289946 & 88.9 & 86.9 & 92.5 & 5 & 93.0 & 89.9 & 3.2 & 1.22 & 91.8 & 0.55 \\
\hline TNX 220 & 3674265.5 & 429022.9 & 87.8 & 85.8 & 90.5 & 5 & 91.0 & 88.7 & 2.3 & 0.89 & 90.2 & 0.40 \\
\hline$T N \times 23 D$ & 36747783 & 429090.4 & 104.8 & 84.8 & 152.8 & 6 & 100.8 & 97.6 & 3.3 & 1.39 & 99.3 & 0.57 \\
\hline$T N \times 240$ & 3674917.5 & 429218.2 & 114.8 & 99.8 & 140.8 & 8 & 109.7 & 108.3 & 14 & 0.55 & 109.0 & 0.19 \\
\hline$T N \times 260$ & 3674413.3 & 4291014 & 90.1 & 87.8 & 97.1 & 9 & 96.1 & 92.9 & 3.2 & 1.08 & 94.0 & 0.36 \\
\hline TRW 1 & 3674719.8 & 429140.5 & 106.4 & 81.4 & 154.4 & 5 & 93.2 & 89.9 & 3.3 & 1.34 & 910 & 0.60 \\
\hline TRW 2 & 367478.0 & 429087.8 & 112.2 & 7.2 & 152.5 & 2 & 926 & 89.3 & 3.3 & 2.3 & 90.9 & 1.63 \\
\hline TRW 3 & 3674772.5 & 429123.9 & 112.3 & 77.4 & 152.2 & 1 & 81.3 & 81.3 & 0.0 & $\ldots$ & 81.3 & \\
\hline THW 4 & 3674827.0 & 429136.9 & 1119 & 81.9 & 148.9 & 7 & 100.2 & 87.0 & 13.2 & 4.73 & 91.1 & 1.79 \\
\hline$X S B 10$ & 3674696.0 & 429137.7 & 1079 & 87.9 & 153.9 & 37 & 106.7 & 95.9 & 10.8 & 1.71 & 99.2 & 0.28 \\
\hline$X S B 20$ & 3674678.8 & 429123.7 & 104.0 & 84.0 & 153.0 & 40 & 100.5 & 96.5 & 4.0 & 1.07 & 98.7 & 0.17 \\
\hline$X S B 3 A$ & 3674650.8 & 429173.6 & 103.2 & 87.4 & 154.3 & 31 & 1017 & 97.8 & 3.9 & 11 & 100.0 & 0.20 \\
\hline$X S B$ & 3674657.5 & 429140.3 & 1039 & 83.9 & 1529 & 37 & 100.5 & 96.6 & 4.0 & 1.12 & 98.7 & 0.18 \\
\hline YSB $1 A$ & 3674874.3 & 4293529 & 128.4 & 98.4 & 143.4 & 37 & 123.1 & 101.4 & 21.7 & 5.44 & 118.4 & 0.89 \\
\hline YSB $2 A$ & 3674844.3 & 429390.4 & 127.7 & 97.7 & 142.7 & 37 & 124.4 & 99.8 & 24.6 & 5.2 & 119.4 & 0.85 \\
\hline YSB $3 A$ & 3674790.0 & 429394.1 & 126.7 & 96.7 & 141.7 & 38 & 124.4 & 1120 & 12.4 & 2.7 & 119.7 & 0.44 \\
\hline$Y S B A A$ & 367427.0 & 429361.3 & 127.6 & 97.6 & 142.6 & 37 & 122.6 & 994 & 23.3 & 4.97 & 118.3 & 0.82 \\
\hline$Y S C 10$ & 3685217.8 & 439933.4 & 236.8 & 216.8 & 2728 & 2 & 221.6 & 221.1 & 0.5 & 0.37 & 221.3 & 0.26 \\
\hline YSC 20 & 3685303.3 & 439973.4 & 218.0 & 197.9 & 2820 & 18 & 220.8 & 2127 & 8.1 & 2.35 & 216.2 & 0.55 \\
\hline 22 & 362210.3 & 437417.4 & 214.5 & 2140 & 255.5 & 7 & 2207 & 217.2 & 3.5 & 1.29 & 219.3 & 0.49 \\
\hline$z=9$ & 3682368.0 & 436245.7 & 227.5 & 207.5 & 277.4 & 21 & 218.9 & 2120 & 69 & 2.26 & 215.0 & 0.49 \\
\hline 220 & 3680240.5 & 435213.4 & 193.4 & 173.4 & 239.4 & 1 & 183.4 & 183.4 & 0.0 & $=$ & 183.4 & \\
\hline$z 208$ & 3680241.3 & 4352123 & 195.6 & 775.6 & 2411 & 6 & 195.1 & 189.6 & 5.5 & 1.91 & 192.1 & 0.78 \\
\hline$\angle B G 1$ & 3684777.5 & 4401501 & 240.1 & 220.0 & 2889 & 31 & 241.9 & 231.8 & 10.1 & 2.08 & 234.6 & 0.37 \\
\hline$\angle B G 1 A$ & 3684781.3 & 440153.0 & 281.0 & 2760 & 287.8 & 7 & 282.6 & 276.2 & 6.4 & 235 & 279.6 & 0.89 \\
\hline$\angle B G 2$ & 3685014.5 & 440689.6 & 230.9 & 210.9 & 275.8 & 33 & 226.3 & 217.8 & 8.5 & 2.52 & 2219 & 0.44 \\
\hline $\mathrm{ZOT} 1$ & 3683476.5 & 440920.4 & 247.0 & 227.0 & 263.0 & 27 & 241.6 & 238.7 & 29 & 0.73 & 240.0 & 0.14 \\
\hline$\angle D T 2$ & 3683479.5 & 440897.5 & 245.1 & 225.1 & 263.1 & 27 & 243.3 & 240.3 & 3.0 & 0.85 & 241.5 & 0.16 \\
\hline $2 W^{2}$ & 3683784.3 & 436653.8 & 204.8 & 194.8 & 286.7 & 13 & 210.5 & 203.4 & 7.1 & 2.06 & 207.9 & 0.57 \\
\hline $2 W 3$ & 36842778 & 437308.3 & 205.1 & 194.6 & 2579 & 13 & 2044 & 198.2 & 6.2 & 1.87 & 2012 & 0.52 \\
\hline $2 w 4$ & 3683425.5 & 437732.0 & 239.7 & 229.2 & 270.2 & 12 & 2358 & 230.4 & 5.4 & 1.45 & 233.1 & 0.42 \\
\hline $2 W 5$ & 3682626.0 & 437617.4 & 2310 & 2210 & 273.5 & 17 & 230.3 & 225.3 & 5.0 & 11.24 & 227.5 & 0.30 \\
\hline $3 w 6$ & 3682244.0 & 436886.3 & 227.2 & 2167 & 2669 & 11 & 223.1 & 2169 & 6.2 & 177 & 2202 & 0.53 \\
\hline $2 w 7$ & 3682799.3 & 4395990 & 2648 & 254.5 & 270.1 & 12 & 2680 & 263.6 & 4.4 & 1.54 & 266.0 & 0.44 \\
\hline$z w 9$ & 36831933 & 439726.6 & 252.4 & 242.4 & 2857 & 14 & 255.1 & 249.2 & 5.9 & 1.75 & 2526 & 0.47 \\
\hline $2 w 10$ & 3683555.5 & 440217.0 & 252.2 & 242.2 & 297.6 & 19 & 263.4 & 2456 & 178 & 3.95 & 2506 & 0.91 \\
\hline$N P M 2$ & 3680130 & 440770 & 264.2 & 244.2 & 334.9 & 1 & 267 & 267 & & & & \\
\hline $\mathrm{NPM} 3$ & 3679389 & 440241 & 267.2 & 247.2 & 333.9 & 1 & 267.6 & 267.6 & & & & \\
\hline $\mathrm{NPM} 4$ & 3679409 & 440904 & 276.7 & 256.7 & 311.6 & 1 & 2727 & 2727 & & & & \\
\hline NTS 2 & 3673765 & 440720 & 194.8 & 174.7 & 244.3 & 1 & 192.3 & 192.3 & & & & \\
\hline NTS 1 & 3673374 & 440277 & 184.4 & 164.3 & 233.9 & 1 & 180.4 & 180.4 & & & & \\
\hline NTW 3 & 3673867 & 438906 & 194.8 & 176.7 & 244.3 & 1 & 191.8 & 191.8 & & & & \\
\hline NTW 4 & 3673606 & 439273 & 185.8 & 166 & 226.2 & 1 & 180.4 & 180.4 & & & & \\
\hline NTW 2 & 3673354 & 438579 & 191.5 & 171.5 & 243.1 & 1 & 183.9 & 1839 & & & & \\
\hline NTw 1 & 3673385 & 438898 & 188.8 & 168.9 & 2449 & 1 & 183.6 & 183.6 & & & & \\
\hline NTN2 & 3676803 & 438851 & 227.2 & 207.2 & 2547 & 1 & 2352 & 235,2 & & & & \\
\hline NTN 1 & 3676361 & 438731 & 2324 & 2124 & 257.8 & 1 & 233.7 & 233.7 & & & & \\
\hline $\mathrm{NPN} 1$ & 3683283 & 443234 & 277.4 & 2573 & 335 & 1 & 277.5 & 277.5 & & & & \\
\hline NPN2 & 3683761 & 443512 & 278 & 2579 & 327.5 & 1 & 273.5 & 273.5 & & & & \\
\hline $\mathrm{NPN} 3$ & 3683458 & 442786 & 280.1 & 260 & 315.2 & 1 & 276.7 & 276.7 & & & & \\
\hline $\mathrm{NPN} 4$ & 3682987 & 443503 & 285.5 & 265.4 & 305.1 & 1 & 278.5 & 278.5 & & & & \\
\hline EIS 1RP & 3680880 & 443775 & & & 330 & 1 & 309 & 309 & & & & \\
\hline EIS $2 R P$ & 3683585 & 447010 & & & 312 & 1 & 269 & 269 & & & & \\
\hline EIS 3AP & 3686555 & 449580 & & & 286 & 1 & 273 & 273 & & & & \\
\hline EIS $4 R P$ & 3686175 & 455035 & & & 285 & 1 & 278 & 278 & & & & \\
\hline EIS 5RP & 3682680 & 450750 & & & 261 & 1 & 234 & 234 & & & & \\
\hline
\end{tabular}

